\title{
JAVANESE WAYANG KULIT IN THE TIMES OF COMEDY: CLOWN SCENES, INNOVATION, AND THE PERFORMANCE'S BEING IN THE PRESENT WORLD' Part Two Jan Mrázek
}

The first part of this essay was published in the previous issue of Indonesia.

3. The Puppeteer with his Puppets as the Guest Star at a TV Variety Show, or Pesta gado-gado ("mixed-salad celebration")

Kolosal and Spektakuler Performances in the 1990s

The wholeness of the whole of the performance is changing, as are the details. To give a more concrete picture of, a better feeling for, how the various innovations or tendencies examined in the previous parts of this essay appear together in a performance, and how important is the change of the whole, it should be useful to draw a sketch of several new-style performances. In that context, I will also discuss some additional aspects of wayang's presence in contemporary Java.

\footnotetext{
1 The essay was revised and the Postscript was written as a part of the VA|AVMI Research Project, University of Leiden. I am grateful to Ben Arps for his support.
} 
108 Jan Mrázek

The first performance that I want to describe, which took place in Solo on March 10,1990 , is from our point of view historical: it is one of the many performances that I could have chosen from the early 1990s that clearly manifested various new tendencies, but was still notably different from today's new-style performances. The mere fact that the performance was announced and reported in a number of newspapers and magazines tells us something about its character. ${ }^{2}$ There are many wayang performances taking place in Java every night, but typically they do not interest the media: they are commonplace. That this performance was reported in the media suggests that it was new, even sensational, that it was not commonplace. Its newness-a sort of strangeness-was itself a major attraction.

The most apparent innovation was that there were two screens and three dhalangs (puppeteers)-in connection with this, the comparison of the performance to multiplex cinemas in the quotation below should be noted. The location of the performance, too, was commented on by the newspapers. One article starts out by describing the place, finding it, apparently, to be one of the "newest" things about the performance:

People's memories of when the world of film was hit by the "revolution" of the mushrooming multiplex cinemas [cineplax] have not yet disappeared. It seems that the world of wayang does not want to be left behind. Last Saturday night, there was a wayang kulit performance using two screens and three dhalangs. And even the place of performance was Women's Building Sasana Kridha Kusuma, grandiose and fully air-conditioned [full $A C]$. One feels that the enjoyment of looking at a film in a multiplex cinema was carried over [terbawa] into the "enjoyment" of watching wayang kulit that night, in the sense of a particular enjoyment. ${ }^{3}$

In this quotation, the experience of watching wayang in full $A C$ is compared to the experience of watching films in movie theaters, specifically multiplex cinemas that are, in comparison with other kinds of movie houses in Indonesia, the most expensive, ostentatiously modern, new, and urban, that show mostly foreign films, and emphasize the physical comfort of the viewers. Full $A C$ is another way in which wayang imitates, or is inspired by, film, and the change of atmosphere, of the air temperature, is one of the radical changes in this particular performance. While other, outdoor wayang performances are integrated into the changing atmosphere and temperature of the night air, and their musical and dramatic progression is enhanced by it, ${ }^{4}$ the cool air of full $A C$ is not integrally connected to the performance; its appeal is separate, and juxtaposed as the appeal of yet another attraction. It is the appeal of the new and the foreign, the various manifestations of which I have discussed at length in the previous parts of this essay, and it also carries implications of grandiosity (megah), and thus money and status. Only richer people go to modern multiplex

${ }^{2}$ On this particular performance, see especially "Peringati Super Semar: Akan Dipergelarkan Wayang Kulit 'Simponi Tiga Dalang,'" Suara Merdeka, March 5, 1990; "Dengan Dua Layar dan Tiga Dalang: Wayang Kulit Juga Ingin 'Ngetrend,'“ Kedaulatan Rakyat, March 14, 1990; "Memadukan Baladewa dan Nurlela," Tempo, March 17, 1990, p. 85.

3 "Dengan Dua Layar dan Tiga Dalang: Wayang Kulit Juga Ingin Ngetrend."

${ }^{4}$ For how it is so, see Jan Mrázek, "Phenomenology of a Puppet Theater: Contemplations on the Performance Technique of Contemporary Javanese Wayang Kulit" (PhD Dissertation, Cornell University, 1998), Chapter Seven. The study will be published as a book by the KITLV Press, Leiden. 
cinemas or ride on $A C$ busses (where many suffer terribly, because the $A C$ is always turned on max), and the richest (in villages seen only on TV) travel in $A C$ cars. The cool air in a full $A C$ building, the atmosphere, suggests this moderen world. By the way, the coolness of the air, while it connotes delicious foreignness and grandiosity, is rarely enjoyed for its own sake: Javanese nights, especially for Javanese, are cool enough, and spectators often wear thick jackets or blankets, and when Javanese are asked what is the advantage of watching wayang on TV one of the most common responses is: because they do not have to be out there in the cold. ${ }^{5}$

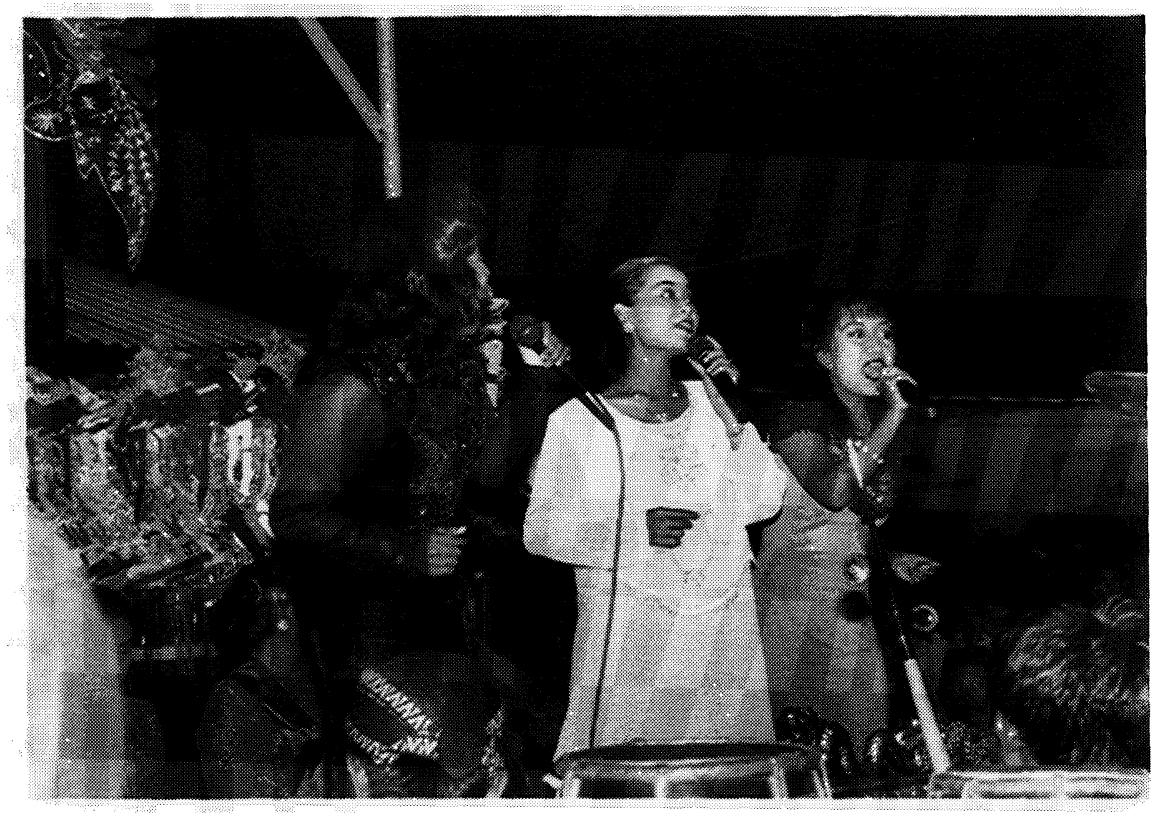

Figure 1. A major development in wayang performances is the inclusion of pop music and pop singers. They stand up next to the dhalang and other performers and the gamelan instruments, an action which many people consider extremely impolite. The three pop singers are accompanied by a mixture of gamelan and non-gamelan instruments (electronic keyboards, rock percussion set, etc.) at a wayang performance near Solo. (Dhalang: Crazy Djoko).

Rather than opening this particular 1990 performance with the customary slow, stately, grand audience scene,

... [t]he performance was begun with the sabetan [puppet movement/puppet manipulation, and in this case puppet acrobatics] of Ki Manteb on the right screen. The dhalang appeared to mesmerize [the audience], accompanied by gamelan, [Western] drum [drum] blasts, and flute, and shining spotlights. He immediately brought out [the female clowns] Cangik and Limbuk [thus immediately commencing the first clown scene]. [. . .] When Cangik was tired of chatting, she asked Limbuk to sing. Then, the spotlight moved to the row of pesindhens [female singers]. Heard was the pop song which is still top [top],

\footnotetext{
5 For a more in-depth discussion of how wayang is watched on television, see Jan Mrázek, "To Be Or Not To Be There: Watching Theatrical Performances on Television," in Puppet Theater in Contemporary Indonesia: New Approaches to Performance Events, ed. Jan Mrázek (Ann Arbor: Center for South and Southeast Asian Studies, The University of Michigan, forthcoming).
} 
110 Jan Mrázek

Nurlela, from singer Diah P.H. In Ki Manteb's hands, Limbuk was played [i.e., moved] with agile movements, imitating people at disco [orang berdisco, "discoing people"], as if it was she who was singing. The spectators were screaming and laughing wildly.

The performance of this wayang plus [wayang plus] was not telling the story of Limbuk. The official story [cerita resminya] was Baladewa-Baladewa. ${ }^{6}$

In addition to noting how the reporter recognizes the importance of the spotlights, of spectacular sabetan, singers, and pop music-separate and juxtaposed attractionswe should also note that the story, according to the report, is merely the "official story [cerita resminya]": the report implies that the story stands apart from the reality of the performance. The story, incidentally, is also moderen, for it "smells a little of politics and espionage," because "this is the kind of story that is enjoyed."7

We have examined what happens when there is more than one dhalang and when there are two screens, how the dhalang and his puppets no longer command center stage, how the puppeteer loosens his connection, his "organic bond," to the puppets and compromises his sovereignty as he becomes only one of the performers (comedians, singers, dhalangs). Reports of this 1990 performance show us how the three dhalangs were reduced to become mere members of a company of performers: "Apart from three dhalangs, namely Ki Manteb Sudarsono, Ki Sugito, and Ki Hadiwiyono [sic], there were the langgam singer Waljinah, pesindhen Nyi Minten [one among the sixteen pesindhens present ${ }^{8}$, pop singer Diah P.H., and local rocker [rocker setempat] Betty." 9 The following quote also illustrates the drastically reduced role"light task" - and the reduced powers of the dhalangs and how the dhalang has become further disconnected from the puppets:

The gara-gara scene was next. There appeared Semar, Bagong, Petruk, and Gareng [the clowns]. Ki Dalang Sugito played them. But the task of this Ki Dalang was light. He was only "showing off" ["memperagakan," in quotation marks] their movements. Their voices came from the leading comedians from the Wayang Orang Sriwedari lead by Surono. ${ }^{10}$

One more thing needs to be noted about the presence of the three dhalangs in this particular performance. The performance was said to have adopted "the model of presentation which combines several [regional] styles."11 Manteb, according to the press, "represents" Solo and Yogya (the combination of these two wayang styles, in the recent past still considered a major innovation, is here taken for granted), Ki Sugito represents the Banyumas style (West Central Java), and Ki Djoko Hadiwidjojo (Crazy Djoko) represents the style of pasisiran (the North-Java coast). ${ }^{12}$ This is another manifestation of the tendency to mix regional styles, which we discussed earlier when

\footnotetext{
6 "Memadukan Baladewa dan Nurlela."

7 Tbid.

8 "Peringati Super Semar."

9 "Memadukan Baladewa dan Nurlela."

${ }^{10}$ Ibid.

11 "Dengan Dua Layar dan Tiga Dalang."

12 See ibid., and "Peringati Super Semar."
} 
speaking about music and the presence of gara-gara in performances. But in reality this is not a collaboration of equals: Solo is the "home," so that dhalangs from the other regions represent the foreign. For spectators in Solo, Manteb would be by far the most famous dhalang and his style the most familiar. Crazy Djoko, who performs basically in Solonese style, would be more alien, for Djoko's North Javanese style is marked by the presence of more radical innovations unacceptable to many Solonese dhalangs like Manteb or Anom (for instance, the fact that singer or comedian stands up). Sugito is an excellent dhalang, but largely unknown in Solo, and his style, for the Solonese, is quite foreign. In this context, the word "represent" (mewakili, from wakil, "representative, deputy-, vice-") becomes interesting in its own right. There is a sense that the dhalangs, rather than genuinely combining the styles, merely represent them in one performance; it is as if the styles were somewhere else, separate, and in the performance only their deputies, their representatives, their emissaries, were present. What counts is their being foreign, being from "other regions." Or perhaps they are somewhat like the "samples" of sounds of various instruments played on keyboard in Manthous's Campursari, so that this performance too "plays with sampling" (bermain sampling), to use Manthous's words. ${ }^{13}$

The event was called "Simponi Wayang Tiga Dalang, Sebuah Eksperimen Kreatif Mamadukan Seni Wayang dan Musik" ("A Three-Dhalang-Wayang Symphony, a Creative Experiment Blending Wayang Art and [Western or non-gamelan] Musik"). Langgam, pop, and rock songs were played to the accompaniment of gamelan and a (Western) percussion set ("a song which is usually presented with the accompaniment of pop musik [musik pop] was conjured to a form accompanied by gamelan blended with drum $\left.^{\prime \prime}\right){ }^{14}$ The title emphasizes the importance of Western or non-gamelan musik in this simponi, and its blending with "wayang art" (which presumably includes gamelan). This performance took place, by the way, at about the same time that Manthous was beginning to become popular with his Campursari. In addition to the originally non-gamelan songs, the performance also included the light gamelan composition "Jineman Uler Kambang." According to the report, this composition "represented traditional values [mewakili nilai tradisi]." 15 As noted above, the word mewakili ("represent") occurs earlier in the same article and in another report on this event. It is used to refer to the "other styles," and I have suggested that these styles must be represented because they are somewhere else, and that they are enjoyed as representations, as signs of the foreign. Here one begins to wonder: is gamelan music, too, "represented" in this way? Is it too like a sample? Is it one attraction among many, and, moreover, is it the "representative" or the "deputy" (wakil) of something that is somewhere else and not really here, something that needs to be represented here, "traditional values"? Is gamelan itself becoming foreign and appealing because of that, at a performance such as this?

The title of the report on the event in the magazine, Tempo, echoes one word from the title of the show. According to the title of the show, the event blends (memadukan) wayang art and musik; the article in Tempo is called "Memadukan Baladewa dan Nurlela" ("Blending Baladewa and Nurlela"). Baladewa is a king in wayang, and the

\footnotetext{
${ }^{13}$ See Indonesia 68, p. 50.

14 "Dengan Dua Layar dan Tiga Dalang."

15 Ibid.
} 


\section{Jan Mrázek}

protagonist of the plot in this performance. Nurlela is the pop song sung at the performance. Again, emphasis is on blending-blending the wayang performance and the world it represents, with the world of pop music shows, the present world. Judging from these titles, the performance-whatever was meant to impress and has impressed itself on people-is the blending itself, rather like in the case of Campursari. The performance is blending or mixing on many levels and in different areas.

One newspaper article explains why the spectators watched the performance so carefully:

It indeed makes sense that the spectators followed the presentation closely. Why? The organizers [ . . . ] presented a separate/special trick to attract the interest of the spectators. In the presentation, there were three Setyaki characters, and two among them were false [palsu]. Here the organizers offered a question along with a gift for the spectators to find the original Setyaki, [and the answer had to be] complete with its reasons. The gift was a color TV and other entertainment gifts. Practical [praktis]: whether they wanted to or not, the spectators who were dreaming of the TV gift had to follow the progression of the story carefully. ${ }^{16}$

As noted above, films were "represented" at the performance by the full $A C$. In this article I have also discussed the complex interaction between wayang and films/TV, and the impact that this interaction has had on wayang (as exemplified by Manteb's sabetan, which was also featured at this performance). Here we have an example that manifests in a subtle way the same interaction. The "trick" itself, the "question with a gift," is especially associated with TV, and more generally with modern advertising practices. (We might remember that Manteb would soon become bintang iklan, the "advertisement star.") That the gift is a color TV is both ironical and indicative of the situation. Organizers motivate the audience to watch wayang carefully by having them, as they watch wayang, "dream of the TV gift" (memimpikan hadiah TV itu)-"whether they wanted to or not." This may seem a funny coincidence, an irony, a joke not intended by the organizers ... as if a teacher who was trying to wean children from TV and encourage them to visit the library decided to put TV sets into the library and throw out the books. But for the organizers the trick was praktis ("practical"). In this kind of "little coincidences," the complexity of the way that wayang is in the present world manifests itself perhaps more truly and more eloquently than in cases where, say, we find a clear influence of TV on wayang. By the way, TV was not present only in this offer and the dreams of possession it generated. Those spectators who were not eligible to compete for the TV because they were not part of the audience inside the airconditioned hall were watching the performance outside the hall, where it could be seen on a giant TV monitor. ${ }^{17}$

\footnotetext{
${ }^{16}$ Ibid.

17 Ibid.
} 
One and half years later in Semarang, in October 1991, there was another performance that I wish to mention especially because it developed one essential characteristic even further. "Semarang presents wayang kolosal," announces the subtitle of a report on the performance in the "Teater" section in the Jakarta-based Tempo magazine. ${ }^{18}$ The performance was "kolosal, as seen from the number of artists involved, the gamelan instruments, and the size and design of the stage," writes the major newspaper in Semarang, calling it "spektakuler."19 "The dhalang from Solo," Anom Suroto, is quoted saying that the performance was "kolosal." 20 The kolosal-ness and the spektakuler-ness are the major characteristics of this performance, and it was described in appropriate terms. With an estimated audience of fifty thousand spectators, the performance used a stage fifteen meters deep and forty meters long; there were three screens and three gamelan sets with seventy-three gamelan-instrumentalists, twenty-one pesindhens, and ten male singers, an "entertainment team [tim]" consisting of Jujuk from the Sri Mulat comedy shown weekly on TV, the famous transvestite dancer Didik Nini Thowok and the comedian Ngabdul from Yogya, and-we have noted the importance of the microphone-there was a "sound system with thirty microphones," according to the press report. In the gamelan, "there was a conductor as it is the case at [Western] musik concert [konser musik]" (the conductor was Subono, whom I have mentioned as the composer who collaborates with Manteb and other dhalangs). There were six dhalangs, and "they were all dexterous showing off puppet movement [trampil memperagakan sabetan]." The article in Tempo relates this performance's various special effects (especially lights of various colors) to Sukasman's experiments with wayang, which I discussed earlier. ${ }^{21}$ As in the 1990 performance, the emphasis was on spectacular fighting scenes ("action"), and especially on the clown scenes with their comedy, music, and dance. At this performance, too, music from "other regions" was an attraction. Apart from music and dances from various parts of Java, there was an "outside-Javanese 'gendhing" ("gendhing' luar Jawa), and the "English 'gendhing' My Bonnie" (gendhing is in quotation marks in the original). There was no AC at this openair event-this may seem a strange observation, but the newspaper comments and reflects on the fact at length. This observation, and observations about the shortened time of the performance, show that this kind of wayang is, in people's minds, often related to film, TV, and video:

Another problem that has to be considered more is the length of time required to perform a wayang story. Through film, television, as well as video, people of these times are already used to enjoying a story or a fairy tale that takes about two to three hours. And even that while sitting in a cushioned chair in a hall with $A C$. Being spoiled like this may make people consider watching a wayang performance as self-torture, because they have to jostle in the crowd and fight sleepiness due to the performance's length. Well, would it be possible for wayang spectators to have comfort [kemanjaan, "what spoils"] like the spectators in a

18 "Enam Jam di Simpang Lima," Tempo, October 19, 1991, p. 70.

19 "Pesona Wayang 6 Jam," Suara Merdeka, October 12, 1991.

20 Ibid.

21 For a new essay on Sukasman's experimental wayang, see Hardja Susilo, "The Personalization of Tradition: The Case of Sukasman's Wayang Ukur," in Puppet Theater in Contemporary Indonesia, ed. Jan Mrázek (forthcoming). 


\section{Jan Mrázek}

movie theater? Of course it is possible. However, there will be another problem, because if a wayang kulit performance in the open requires much expense, what then [would it cost] if it were in a hall with $A C$ ? $^{22}$

$A C$ is not, even today, common at wayang performances. But hypothetical musings of this kind suggest that $A C$ is generally associated with multiplex movie theaters and the modern, electronic media, and $A C$, too, enhances wayang performance rather like the television antenna used to modernize the Greek puppeteer's old and otherwise unchanged hut, or the symbolic radio antenna used to modernize the pedicab in Solo (see Indonesia 68, p. 113). Also, commentaries of this sort show how much at least some people think about movie theaters and TV when they watch a kolosal wayang performance. Even the name of this experimental performance articulated the connections to cinema, or perhaps the aspiration to be like cinema. It was called "Six Hours at Simpang Lima" (Enam jam di Simpang Lima, ${ }^{23}$ an allusion to the 1951 classic Indonesian movie, "Six Hours in Djogdja" (Enam djam di Djogdja). That film, which celebrates the struggle for independence, is familiar to most Javanese because on national holidays it is frequently screened on TV.

The two performances, in 1990 and 1991, were major events because of their size and their displays of radical innovations. If I were writing a history of the innovations-which I am not-we would have to look at many other events and experiments within the wayang medium to locate more carefully these performances in a context. But rather than looking at the historical development "behind" these two performances (which I have done in part earlier), I describe them here in order to give a better picture of what was soon to come after them, that is, the developments in the 1990s. The major development is this. While these two performances were presented and seen as "experiments" (eksperimen), what happened in the following years, and what is still happening today, is that performances very much like these two are taking place, but they are not considered experimental in the way they were before. There are usually several kolosal, spektakuler events like this every month in different cities in Java (though there are fewer super-kolosal events during the economic crisis), and since they are generally broadcast on television, people have grown rather used to them and even come to expect them. This does not mean that they have quite lost their strangeness, their newness; the performances are still huge and exceptional events, and that is their major attraction. Rather, the kolosal-ness, the spektakuler-ness, the strangeness, and the newness is becoming more widespread, and people expect to see this newness and strangeness.

The large-scale performances generally involve a stage, many pesindhens, standing comedians, singers, a rock band, and so on. The largest performances may have two screens and two or three dhalangs, organized in standard set-ups that I have already described, though many large-scale performances involve only one dhalang. In some cases, these events may be somewhat smaller than the two performances described

\footnotetext{
22 "Pesona Wayang 6 Jam."

23 Simpang Lima is the large square in Semarang where the performance took place.
} 
above, but sometimes they are even more spektakuler and kolosal. While we have seen that the 1990 event involved sixteen pesindhens and the 1991 event had twenty-one (a long way from Nartosabdho's then-sensational four pesindhens in the 1960s), a performance I attended in the summer of 1996 (celebrating the fiftieth "birthday $[H U T]$ " of the town of Sukoharjo), for instance, involved fifty pesindhens (to symbolize the fifty years), in addition to a number of pop music singers, comedians, and other guest stars. Moreover, many smaller events imitate the large ones, and many a village wayang, with only one screen and one dhalang, involves standing pop and rock singers, as many pesindhens as the dhalang can find, keyboard and other musik instruments, color lights, and other attractions, and generally there is an attempt to make even small and medium-size performances spektakuler. Thus, the kolosal-ness and spektakuler-ness of the kolosal performances is imitated even by events that cannot afford to be quite as kolosal, which is another way in which the characteristics of the kolosal, spektakuler performances are becoming more widespread (and continue to proliferate during the economic crisis; see the Postscript).

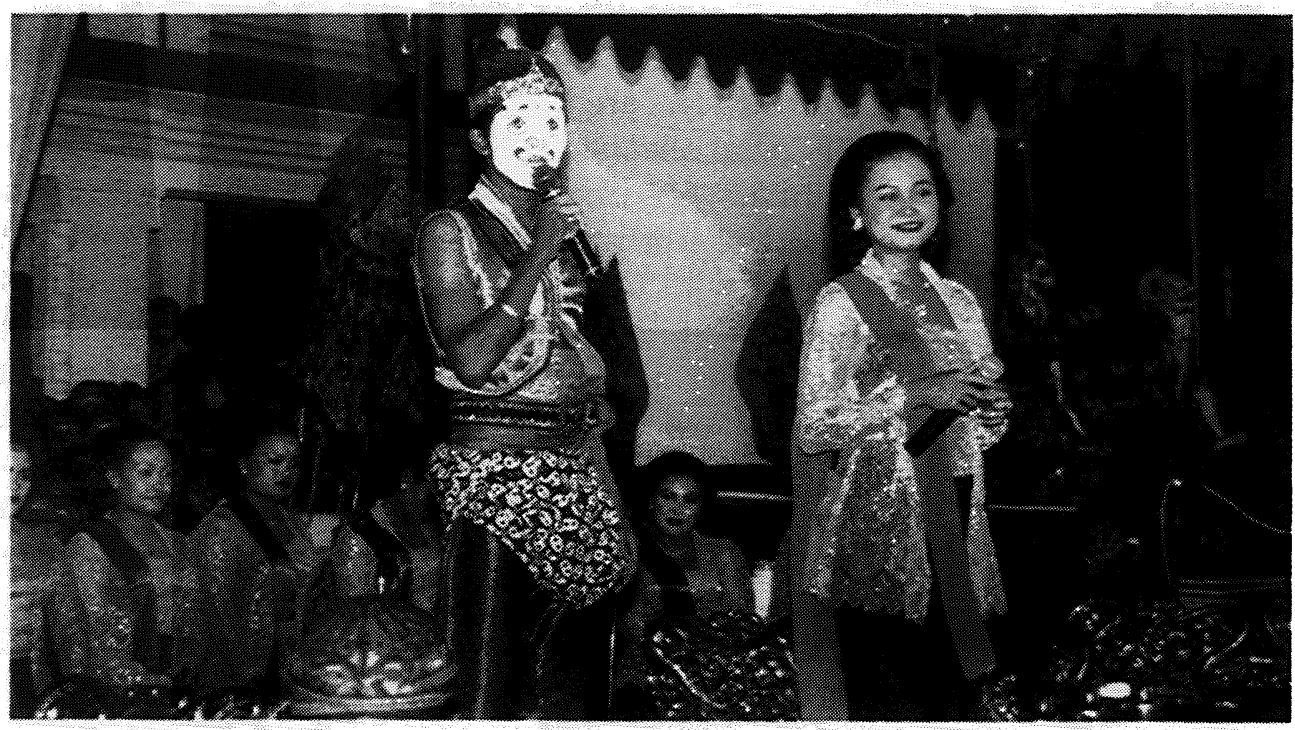

Figure 2. Guest stars displace the puppets. Gareng, one of the clown servants, is represented in this two-screen wayang performance not (only) by a puppet, but also by a live comedian (a wayang orang actor). Standing on a stage between two wayang screens, at the center of the performance area and in the spotlight, he is talking to and singing with the pop and langgam singer Nurhana, one of the wives of the dhalang Crazy Djoko. Other guest stars, singers and comedians, were also present at this performance sponsored by Golkar.

Wayang On the Market: Night Fairs, Politics, Competition, and the Dhalang as a Celebrity and as a "Presenter"

That the wayang performances are now kolosal and spektakuler is their basic characteristic, and this has further implications. Pak Naryo said that today the wayang performance is like a pasar malam (a "night market"). This is true on several levels. Even a wayang performance that is considered traditional has something of the night-market in it, but large scale performances are like night markets in new ways. While in small-scale village performances there are usually three or four stalls selling 
116 Jan Mrázek

refreshments, cigarettes, and toys, in the large-scale events one often finds dozens of these stalls, and the variety of goods sold is much wider; apart from greater variety of food and drinks, one can sometimes buy clothes, books, knives, ceramics, and so on. But people do not only, or even primarily, shop at pasar malam; one goes to pasar malam to nonton pasar malam-"to watch," as one watches wayang. At a typical pasar malam, people not only observe shops and other people, but they also watch various entertainments. A history of Sri Mulat describes the early days when this kind of comedy first appeared at pasar malam:

The appearance of comedians on the stage [Sri Mulat, originally, was a primarily music revue], apart from refreshing the atmosphere, also attracted spectators so that they would enjoy being at the place. It has to be remembered that in one area of the pasar malam, each group-such as ludruk, wayang orang, kethoprak, gambus, reog, magicians, circus, and so on-competes hard to get as many viewers as possible. ${ }^{24}$

The large-scale wayang performances are like pasar malam in that they combine various attractions and genres into one event, and in the case of the contemporary wayang performances, the various attractions are brought onto one stage. On the one hand, wayang kulit is central in this pasar malam, in the way that kethoprak, gambus, reog, magicians, and the circus performers, for example, are not; the whole event is still defined as a wayang performance. On the other hand, each attraction-even when there is a single stage-has to compete with other attractions on that stage, it has to "show off," and it also competes with the stalls and other available pleasures. Even as these attractions compete with one another, together they-along with the puppeteer and the puppets-constitute the whole event, and the event is a market or like a market. As hawkers at a market do, each works for his or her own immediate profit. The entertainment offered at a pasar malam is essentially fragmented, unfocused, discontinuous; it is a loose bringing-together of various attractions, and this is characteristic of the new wayang performances as well. Such a potpourri, gado-gado, of attractions, fits the event. The dhalang Slenk actually pays a street musician, singing and accompanying himself on a home-made bamboo instrument adorned with two stickers displaying the INDOSIAR TV-network logo, and, in large letters, MUSIK BAMBU, as shown in Figure 3. He acts as a "guest star" in all his performances. On one occasion Slenk sponsored "festival Heek" (Heek is a portable food stall), at which a very large number of these food stalls were brought together to enliven his performance. ${ }^{25}$ People move around at such events and expect excitement and easy entertainment. The wayang show is at the center, but it is a fragmented center, as it consists of many different attractions (even the management of the performance is fragmented). Rather than being tied to a particular house, with clearly established symmetry and center, ${ }^{26}$ the new wayang performance spreads itself like a market in a large open space, as the largest conglomeration of attractions in a field of attractions, and it is open like the space in which it takes place. This is an aspect of wayang being

${ }^{24}$ Herry Gendut Janarto, Teguh Srimulat: Berpacu dalam Komedi dan Melodi (Jakarta: Gramedia, 1990), p. 36.

25 On the 1996 "festival Heek," see Suratno et al., Warsena Slenk: Kiatnya Sebagai Dalang Laris (Solo: STSI, 1997), p. 53.

${ }^{26}$ See Mrázek, "Phenomenology of a Puppet Theater," Chapter 7. 
kolosal and spektakuler. ${ }^{27}$ In a traditional performance, too, people do not attend to the puppets all the time, but what happens on the screen illuminated by the single blencong lamp is central at a wayang performance, rather like the ring and what happens in it is central at a boxing match. The novelty I am describing-the new atmosphere, and the degree to which what happens with the puppets becomes only one attraction among many, the degree to which it is at certain moments "overshadowed" by other attractions that are "in the spotlight" then-can be clearly felt when one attends a performance.

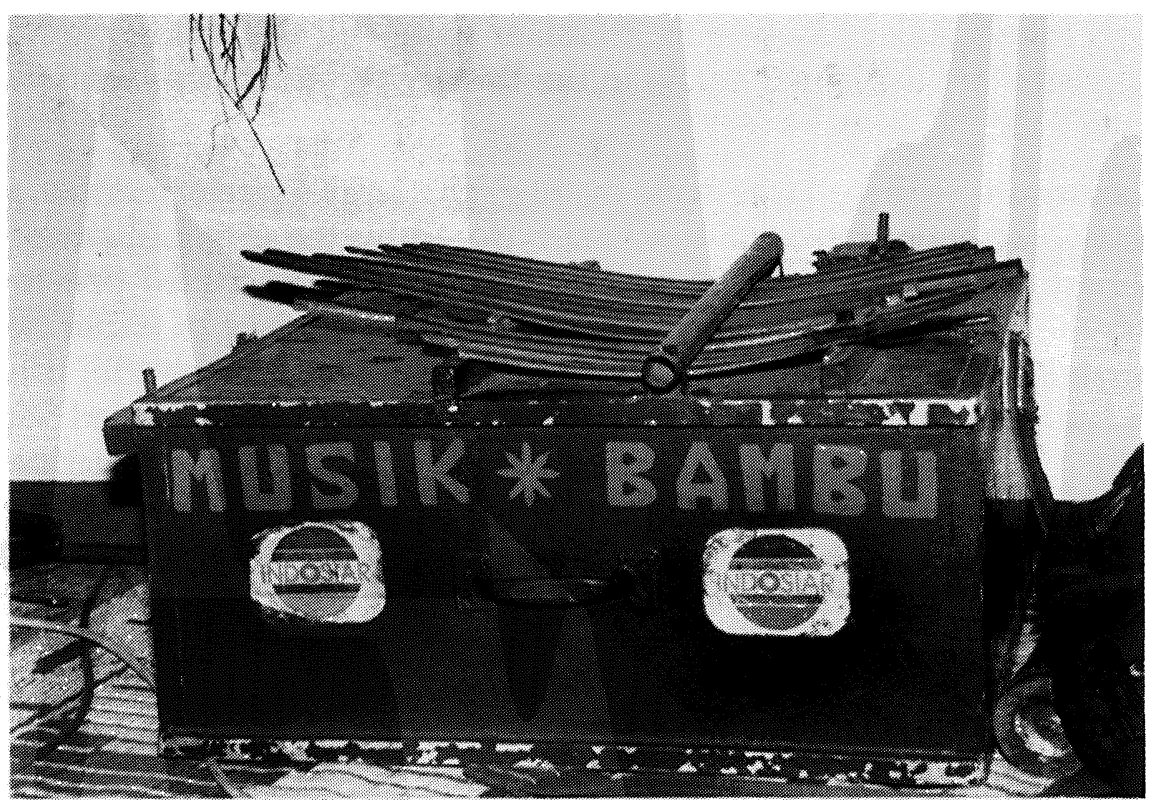

Figure 3. "MUSIK BAMBU": The innovative instrument used by the street musician hired for Slenk's night-market-like performances. Indosiar is the TV-network which regularly broadcasts wayang performances, including those directed by Slenk.

I have mentioned the significance of microphones and amplification. They too affect the atmosphere and the way people watch wayang. According to Pak Naryo, in the past when the dhalang's voice was not amplified, members of the audience listened more carefully, and when they talked, they kept their voices down, while now, with the strong amplification, people do not have to concentrate to hear the sounds of wayang and so tend to be less attentive and to speak loudly. It would be misleading to say that in the past people were listening only to the dhalang, but somehow, amplification changes people's relation to the sounds of the performance and the general soundscape. People hear the performance more easily but listen to it less; they do not have to listen to it in order to hear it, or so Park Naryo's comment would suggest. This too is a characteristic of the atmosphere of the large-scale wayang performances and

27 As in the case of other innovations, I am contrasting the present only to the past that is remembered by Central Javanese performers and audiences. In a more distant past, wayang kulit itself might have been occasionally performed at a pasar malam. As with other developments, increased knowledge about the more distant history of wayang performance-something largely neglected by scholarship-would let us see the present innovations in a different light. 
118 Jan Mrázek

the fragmentation of people's attention. The phenomenon can be compared to the way that strong electrical lights illuminating a stage filled with guest stars change the atmosphere and make the single, focal lamp illuminating the screen and the puppets less central.

[Author's Note: This article was originally written in 1997, before the fall of Soeharto. I have decided to retain the present tense in this following sections, rather than revising them, even though they speak of Golkar as if Golkar were still the ruling party. My reasons for this decision are explained below in the Postscript, which was written at a later date.]

Who are the sponsors of these large-scale events? The largest performances, such as those that use two screens, are consistently sponsored by the government or the ruling party, Soeharto's Golkar. The 1990 performance in Solo discussed previously was sponsored by the government on the occasion of an anniversary of Super Semar (surat pemerintah sebelas maret), the document transferring power to Soeharto; used in conjunction with Soeharto, the word Super Semar evokes both Superman and Semar. At that performance, Sudjadi, a high government official and a Golkar functionary, played a key role, and one often hears that it was he who "invented" the wayang with two screens and more than one dhalang, and who played a role in the popularization of other innovations (he has closely collaborated especially with two dhalangs, Crazy Djoko and Enthus Susmono). The major performances are all yellow. The decoration, the outfits of the performers (including the musicians and in some cases the dhalang), the temporary structure, all are yellow-the symbolic color of Golkar.

It is not difficult to understand why the spektakuler, kolosal wayang needs an extremely powerful sponsor like the government/Golkar. But why does Golkar sponsor the kolosal wayang, and why does it actively participate in making wayang kolosal and spektakuler? The simplest answer is that the government/Golkar tries to attract the masses so that it can convey its messages, which are incorporated into the performance. This does not mean that the performance is therefore reduced to these messages - they form only a very small part of what happens, and most people come for the entertainment-but from Golkar's point of view, this aspect of the performances is important. Tony Day has pointed out that any study of wayang that focuses exclusively on wayang's political aspects, especially on the government's appropriation of wayang, runs the danger of legitimizing the government's perspective. ${ }^{28}$ On the other hand, wayang's involvement with politics is part of its way of being in the present world, and it needs to be a part of our picture.

The kolosal wayang does not only articulate the messages, but it also gives them authority through the kolosal-ness and spektakuler-ness of the event. Apart from incorporating specific messages, such a performance is a show of power. The power is displayed not only by the size of the performance, but also by the performance's-and thus Golkar's-ability to bring people together, to impress the masses with the masses.

28 See Tony Day, "Wayang Kulit and 'Internal Otherness' in East Java," in Puppet Theater in Contemporary Indonesia, ed. Jan Mrázek (forthcoming). Cf. also my "Introduction" in the same book. 
In this way, the large performances are not quite unlike the smaller, more traditional events: in both cases, wayang serves to bring people together, to establish space for encounters among people. And if in the ruwatan ritual not only people but also the demon, Bathara Kala, and other supernatural beings are brought to the event, in the colossal performances the modern demos-masses, rather than individual peopleplay a role. If the ruwatan performances mediate between the sponsor and the demon, the large-scale performances mediate between the sponsor and the demos.

Wayang is partly transformed to fit the needs of a powerful sponsor. This is one of the motivations behind making wayang kolosal and spektakuler: it is done to attract the masses. This, however, is not merely a matter of size, but of the general character of the performance. The performance has to appeal to the penonton-the anonymous audience, the masses. Very often, though not always, the penonton, the masses, are thought of as people who do not really understand wayang, who are not even concerned about it; rather, they are a force in the world that has to be dealt with. As I mentioned above, the emergence of the penonton as a decisive factor in judging the success of a performance has often been cited as the basic cause for the many changes in the character of the performance. Thus a dhalang's concessions to the masses have typically been perceived as signs of his weakness, as well as something characteristic of the times. The penonton became more important, in part, because contemporary wayang has to compete more closely with other shows, with other attractions. However, there is another reason why the masses became important, and that is because Golkar needs to speak to the masses through the performance; it is less concerned with individual people (unless they have influence on the masses or some other kind of power) than with the anonymous masses, the demos. In a democracy, the demos does not necessarily rule, but it figures as a concern and potential danger to the rulers. The rulers have to handle it, control it, and they have reason to be afraid of it (without necessarily thinking what precisely could happen), somewhat like people in ruwatan handle the demons. Thus, Golkar has to be, and is, concerned about the masses, and thus it is eager to see wayang become popular wayang, mass wayang, eager to see it attract people (one old village pesindhen told me that the new large-scale wayangs are wayang massa, "mass wayangs"; a newspaper article uses the term wayang pop, "pop wayang"). ${ }^{29}$ Democracy is like a market, in the sense that it allows for competition, at the same time that typically in a democracy-as in a "free market"whether in America or in Indonesia, various groups or parties try to limit the freedom and scope of this competition, while maintaining the image that it is an open, free competition, because this image legitimizes their power. Just as the many, various performers on a grand stage located at the center of the pasar-malam-like event all compete for the audience's attention, Golkar also competes, even when there is little opposition present. Golkar's wayang performances are trying to attract people in the same way that the various performers at a pasar malam do, and this is another way in which the wayang performance is like a market. Wayang is, first of all, an attraction; and it is an attraction that brings together many attractions. The discontinuous character of the performance-the new performance does not require, and even makes it impossible, to connect things together, which means that it requires less work on the

29 The term wayang pop is used in F. Kamidjan, "Untung Wayang Kulit Masih Ada," Kedaulatan Rakyat, October 27, 1996. 
part of the viewer, that it gives the viewers a break-fits the main purpose of the sponsor, Golkar, which is to attract and bring together the masses, the demos, rather than to bring together human beings as human beings (as happens in more traditional performances, which I have discussed elsewhere). ${ }^{30}$

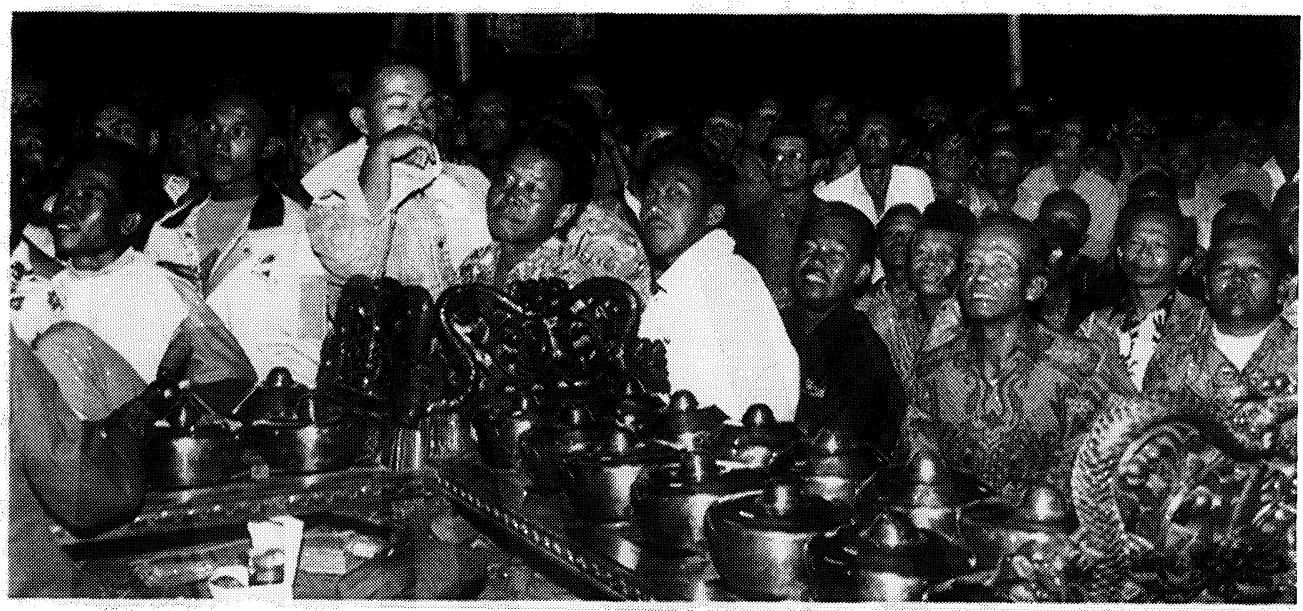

Figure 4. The audience at a wayang performance enjoying a new-style battle scene, performed by Bayu.

This is one way in which the colossal wayangs fit the purposes of the sponsors. I have discussed the increasing tendency for guests or the sponsor to participate in the performance by actually singing or speaking to the dhalang. In these colossal performances, typically a government functionary will come up on the stage and sing a song and talk to the dhalang. This is an opportunity for the sponsor to show himself to the masses, to present a benevolent image of himself as somebody who is together with the people, together with the demos. In a smaller performance there is no need, and it is even considered improper, for the sponsor to become too visible personally (he becomes visible impersonally in the event, in the "having work"), but in such cases most people are personally acquainted with the sponsor (they at least shake hands with him), so there is no need for him to appear on the stage. In the case of the colossal performances, on the other hand, no personal connection exists between the sponsors and the masses, and hence the functionaries feel an urge to be seen not only as government officials representing the party and the government, but as personal, friendly figures; they want to present a human image to the demos . . . as politicians disconnected from people often do ... one thinks of American politicians constantly telling sentimental anecdotes about the poor.

At these mass performances, Golkar is not only present as the sponsor, but is often alluded to or explicitly referred to by the dhalang. Enthus Susmono-one of the "craziest" (or the most "kreatip") top dhalangs-goes farthest in this respect, so that his references to Golkar pervade not only the clown scenes--wherein such references to the sponsor are most likely to appear-but also the other parts of the performance, and some of the stories that he performs are composed to suit Golkar. Nartosabdho,

${ }^{30}$ Mrázek, "Phenomenology of a Puppet Theater," Chapter Seven. 
Anom, and other dhalangs, too, performed Golkar stories. Nartosabdho created stories like "Wahyu Waringin Kencana" or "Wahyu Ringin Mas" ("The Golden Banyan Boom"), 31 which alluded to the banyan tree and yellow (or "golden") color that symbolizes Golkar, and one of the gunungan-"tree of life"-puppets that Enthus used was a depiction of Golkar's banyan tree; its first appearance in the beginning of a performance was sure to be applauded by the watching Golkar functionaries. In one Enthus performance I saw in Semarang in 1996 (sponsored by the Governor of Central Java), Golkar's "tree of life" was shown to emerge from Semar, the father clown. The farting Semar is generally identified with President Soeharto, and in a number of the newer Golkar stories he is the protagonist, as in "Semar Mbangun Kahyangan," "Semar Builds/Develops a Heaven." In an article subtitled "Semar Becomes a Special God," Crazy Djoko (who also "daringly" promotes Golkar) puts it thus: "Semar is indeed a statesman who possesses a strong social awareness [kepedulian sosial yang tinggi], and also a patriot [patriot] who always puts the needs of the people [rakyat] of Amarta first." 32

The whole story of the 1996 performance by Enthus was fashioned to show that Golkar is the right choice for the upcoming general elections. In this story, Bima, one of the Pandhawa brothers, has decided that the government of Ngamarta (the Pandhawa's kingdom) should be replaced, and that he should take over the position of his elder brother, Puntadewa (Bima is supported in this endeavor by a foreign country, which is said to be ateis, "atheist"). Near the end, after Bima's potential "coup d'état" is finally defeated, an evil spirit with a colossal erect penis is seen leaving Bima's body after Bima has been bitten by Semar. In short, Bima's evil behavior-his attempt to overthrow the existing government-was caused by the obscene evil spirit, and Bima, now having regained his own consciousness, realizes that the past was "an unpleasant dream," and that "governing is not as easy as I thought" and should be left to the "rightful" king, the eldest brother. The performance concluded with Semar saying, "May Golkar prosper till the end of times," after which the Golkartree-of-life was planted in the middle of the screen. At the opening of this particular performance, it was explicitly stated that "Semare ya Semar kuning"_-"The Semar, too, is a yellow Semar." 33 The argument here, which was used as part of a democratic campaign, is essentially feudal-Golkar, with Soeharto at the top, is equated with the king in the feudal world of wayang. While wayang's involvement with politics is nothing new, the degree to which these performances are pervaded by politics is perceived by many people as new. To be more precise, traditionally-and this is still the case in many performances-the references to politics and various kinds of "propaganda" are more covert and rather subtle, and when they are more explicit, they tend to appear in the clown scenes, or they're spoken by the clowns. What feels new in these performances by Enthus and dhalangs like him is the explicitness and the assertiveness of Golkar's message in all parts of the performance, and the

31 On Nartosabdho's involvement with Golkar, see Sumanto, Nartosabdo: Kehadirannya Dalam Dunia Pedalangan, Sebuah Biografi (unpublished S-2 [MA] thesis, Universitas Gadjah Mada, 1990), pp. 101ff.

32 “Duel Kontemporer Manteb Oye Vs. Djoko Edan: Semar Jadi Dewa Khusus," Kedaulatan Rakyat, July 27, 1997.

33 Similarly, at another performance at which most performers were dressed in yellow but one pesindhen was not, the dhalang Warsena Slenk said that even though the pesindhen is not in yellow "batine kuning [her inside/heart is yellow]." 
pervasiveness and strength of Golkar's presence in all parts and all aspects of the performance.

Also, Golkar dhalangs (such as Enthus, but others as well, especially Anom, Slenk, and Crazy Djoko) typically introduce religion into their performances and use it to legitimize both themselves and Golkar. Again, Enthus goes the farthest with this. In his performances, he quotes from the Koran in Arabic. He has hired an expert on Islam as one of the guest stars, and he presents Islamic songs (qasidah) in the clown scenes as well as other parts of the performance (other dhalangs, such as Anom, used these only in the clown scenes). In Enthus's performances, the pesindhens cover their heads-the head covers (jilbab), by the way, are yellow (hint). Another dhalang uses the puppet of Petruk (Semar's son, a clown servant who often indirectly represents the dhalang himself) with a head cover signifying that this Petruk is a Moslem, a fact the dhalang also announces in the performance (see Figure 5). The use of Islam-which, after all, means "submission" - for political purposes was nicely exemplified in the 1996 Enthus performance in Semarang described above. In that performance, the explicitly "yellow" Semar quoted Arabic, and than explained its meaning in Javanese: a religious person has to be "faithful to (1) Allah, (2) the Prophet, and (3) the existing government" (pemerintah ingkang wonten). The use of the Indonesian, rather than the Javanese, word for "government" (pemerintah) implied that the Faithful must be faithful to the existing Indonesian government. This is merely the explicit articulation of how the religion that teaches submission is used to make people submissive to the "existing government."

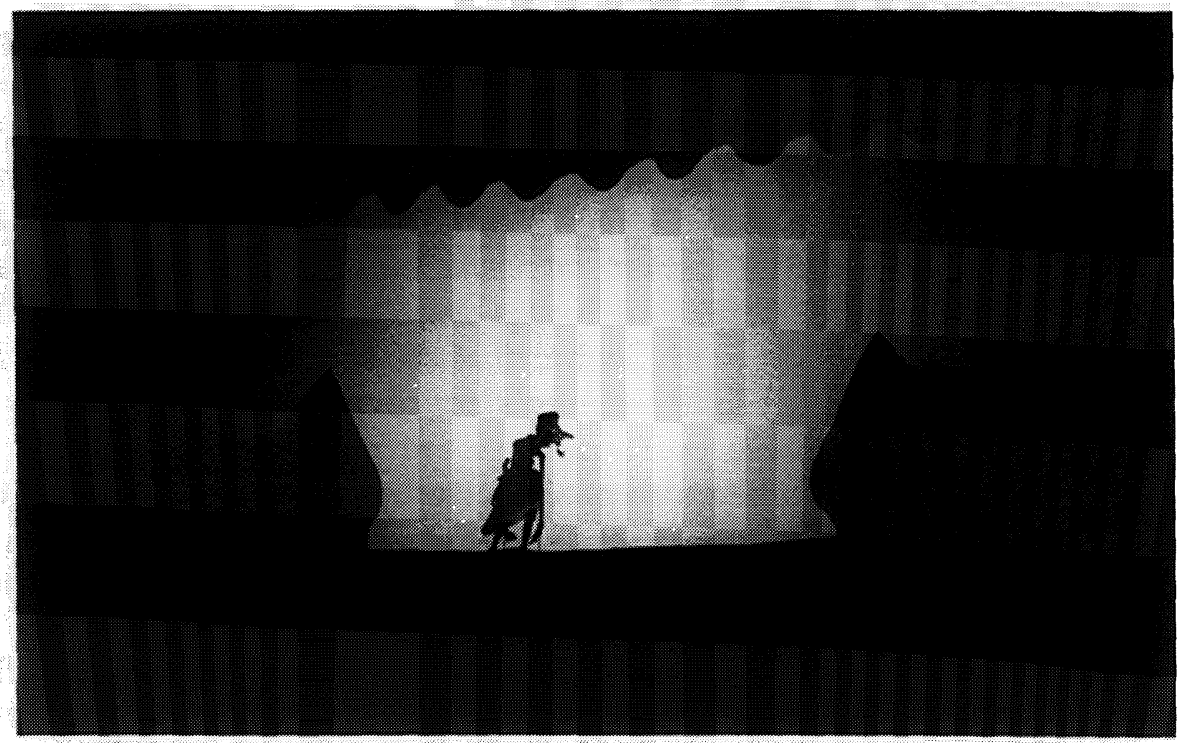

Figure 5. One dhalang uses this puppet of Petruk (Semar's son, a clown servant who often indirectly represents the dhalang himself) with a head cover signifying that this Petruk is a Moslem.

A historical note: not for the sake of completeness, but rather to remind the reader of the limits of my focus. Golkar's involvement with wayang is not quite unique, and previous regimes as well have used wayang for their own purposes. I want to mention only one instance, the involvement of the Indonesian Communist Party (PKI) with 
wayang before the coup of 1965 . First, I refer the reader to Ruth McVey's article which describes the PKI's handling and use of wayang, ${ }^{34}$ and secondly, I would like to point out the striking similarities between the PKI's and Golkar's strategies. McVey writes:

Some of these recommendations [at early New Order conferences on wayang] were peculiar to the political climate of the New Order, but the general lines concur notably with the PKI wayang reformers' vision of what needed to be done, and simply extend the ideas much further. ${ }^{35}$

McVey's article was published in 1986, and she refers here to the early 1970s. It is interesting that in the 1990s the similarity between innovations promoted by Golkar in the New Order and innovations propagated by the PKI in the 1960s have become especially articulate. One can see this whether one looks at some technical aspects of the performance, such as the use of multiple dhalangs, or at the changes in the general character of the performance, such as the radical popularization or "democratization" of the performance. Or one could look at its shifting toward other genres (such as kethoprak); or its new emphasis on the significance of the clowns as well as on the clown scenes (in the case of the PKI, goro-goro dipakai sebaik-baiknya, "the gara-gara is to be used to its best [potentiall]") 36 ; or one might consider the "satirization" of the whole wayang performance (1965: "wayang has become a satire forum [forum satire] which is very much enjoyed by Working People") ${ }^{37}$; or the role of the mass-audience (1965: "let the masses [massa] be the jury in choosing which wayang can best stand the test of the times") ${ }^{38}$; or one might study much of the rhetoric surrounding these innovations. ${ }^{39}$ If today Campursari is popular, in some PKI performances in 1965 there were a number of violins used, and a big drum (bedhug) was played to emphasize the movements in battle scenes, in the same way that a drum is used today. And when Rama's wife Dewi Sinta was about to jump into the fire to prove her purity, the violins played romantic music like in the movies. ${ }^{40}$ Contemporary Indonesian observers, too, note these connections: in a 1997 newspaper article that basically disapproves of innovation, the author argues that if innovation goes "too far," it can have "fatal results" and there will be "a clear answer and victims will be falling," and the article refers to what happened in the sixties after PKI experimented with wayang. ${ }^{41}$ Harmoko, the Minister of Information and one of the top Golkar men, was quoted in an article with the rather ominous title "Dhalangs Who Authorize [consider permissible] All Manners Could Sink." There he made a similar argument against innovation, while adding that "our" innovation does not go too far, whereas PKI's

\footnotetext{
${ }^{34}$ Ruth McVey, "The Wayang Controversy in Indonesian Communism," in Context, Meaning, and Power in Southeast Asia, ed. M. Hobart and R. H. Taylor (Ithaca, NY: Cornell University Press, 1986), pp. 21-52. 35 Ibid., p. 40.

${ }^{36}$ Juliarso, "Introduksi tentang: Wayang dan KSSR," Harian Rakyat Minggu, February 21, 1965.

37 Ibid.

$38 \mathrm{Ibid}$.

${ }^{39}$ For these innovations in the PKI era, see R. McVey, "The Wayang Controversy," and sources cited therein. Cf. also Helen Pausacker, Behind the Shadows: Understanding a Wayang Performance (Melbourne: Indonesian Arts Society, 1996), pp. 29-31.

40 Personal communication with a source who does not wish to be identified.

41 Drs. Soetomo, "Jangan Asal Menyimpang," Suara Merdeka, July 10, 1997.
} 


\section{Jan Mrázek}

did. ${ }^{42}$ McVey notes that the PKI's "formal efforts at revising wayang does not get beyond the experimental stage, as the PKI was eliminated as a legal movement following the coup of 1965." Ironically, many central features of the PKI's experiments-they were actually called eksperimen, like the Golkar wayangs before the mid-1990s-were subsequently popularized by Golkar. McVey's explanation for this apparent paradox still sounds right:

The coincidence of politically opposed views has arisen in part from a shared participation in the moderen culture and the assumption by both the Communist left and military-led right that culture should serve power. In addition, it reflects the broad belief in modern Indonesian political thought, inherited from the independence movement, that the rakyat is the ultimate source of legitimacy and that therefore art's relevance to social needs is essential. Though such concern has often been largely a matter of rhetoric for those in power, it has kept a continuing ideological salience, providing a source of both internal tension and continuity between regimes. ${ }^{43}$

In this essay, we are concerned not only with politics but, more generally, with wayang being a part of the present world. Therefore, I wish to add to McVey's explanation that national politics are only one aspect of "shared participation in the moderen culture," and that, as I have tried to show, there are many other important factors or forces shaping the wayang performance today. That is, the continuity of the innovation process is not only fueled by interaction with the political process, but it is also related to and motivated by the continuity of other forces in the changing world. A history of wayang performance would have to take all the different forces, not only politics, into account. Moreover, a serious study focusing on the interaction between wayang and politics would have to consider seriously the fact that, as Václav Havel (among others) discusses, theater and politics are alike in the way they work with symbols, in the way they are essentially communal, and so forth. ${ }^{44}$ But such an indepth study is beyond the scope of the work. 45

Today, politics are certainly important, especially because dhalangs are dependent on sponsorship, and government functionaries have been for a long time-one could say traditionally-major patrons. On the other hand, I want to emphasize again that it would be misleading to try to explain contemporary wayang's evolution by focusing exclusively on how it has been influenced by national politics. Wayang's being in the same world with other media and other entertainments, the style of life, the interest in anything foreign and, at the same time, a hesitant clinging to things old, as well as the desire to develop the dramatic elements of the theater, to make it more theatrically effective, and the dhalangs' economic capability to improve, or enlarge, the existing technical apparatus (large gamelan, incorporation of other instruments, giant puppets, lights, sound-effects), and the temptations that come with these new possibilities, are some of the other forces that, together with politics (national politics, village politics,

42 "Dalang yang Halalkan Segala Cara Dapat Terperosok," Kedaulatan Rakyat, October 21, 1991.

${ }^{43} \mathrm{McVey}$, "The Wayang Controversy," p. 40.

44 Václav Havel, "Politics, Theater, and Clownery," Czech Theater 12 (1996): 2-8.

$45 \mathrm{Cf}$. (to choose one among many relevant writings) Clifford Geertz, Negara: The Theater State in

Nineteenth-Century Bali (Princeton: Princeton University Press 1980), esp. Chapter Four. 
market politics-which all interact), shape the wayang performance. Wayang has always been manipulated by sponsors, now as in the past. In the same way that dhalangs "dare" to make more changes, so the sponsors, on different levels, participate to a greater extent in the shaping of the performance. For instance, even when the government functionary Sudjadi promotes the various innovations and the popularization of wayang, and thus helps transform wayang, he does it both as a national politician and as a powerful sponsor. In his second role, he follows tradition, for sponsors traditionally participate in shaping the performance, and today theyand the dhalangs - find themselves with more capabilities to change things, not only for the sake of Golkar, but also to manifest their own power and creativity in the role of a sponsor. In other words, at the same time that we do not underrate the importance of national politics, we should not forget that traditionally sponsors have often manipulated the performance to their own needs. Rather, what is new in the mid$1990 \mathrm{~s}$ is that now the sponsors manipulate the performances-at least some performances-radically more. Also, the fact that wayang is deeply implicated in Indonesian politics, in addition to being implicated in local (e.g., village) and Javanese politics, is in some ways a part of wayang being now in a "larger" world. In much the same way, it has also expanded to incorporate not only local music, but also music from other parts of Indonesia and especially pop music popular across Indonesia. The greater impact of national politics on wayang is roughly commensurate with the overwhelming influence of national popular music (such as dangdut), and the greater number of moderen innovations in general.

Moreover, the political forces do not simply coexist with other forces, but they, too, interact. I have referred to the affinity between democracy and free market, and we can see how both encourage wayang to become competitive. Greater competition is seen as a phenomenon of the present world. In the past, according to the dhalangs with whom I've spoken, each dhalang had his own area in which he would perform, and competition among dhalangs, especially those from distant areas, was much less pertinent an issue. What's more, other media were not competing with wayang as aggressively as television and other broadcast entertainments compete now. While these accounts of the past may exaggerate the peacefulness of that time, and performers in the past certainly needed to look for and please sponsors, it is likely that they correctly identify a tendency. Also, the audience is the judge in the newly fierce competition, so that the (mass-) audience too is perceived as a new factor. The competition among dhalangs and competition among various shows, and the political, democratic competition pursued by Golkar, are inseparable. By restraining the potential of other parties to compete and thus restraining the potential of the judge (the demos) to judge, Golkar shows that it takes the competition-democracy-and the judge-the demos-seriously.

I discussed earlier how the competition between wayang and other shows, genres, and media involves a complex interaction with these other media, rather than merely a coexistence and struggle for power. Here I only add that wayang's "being on the market," which involves competition of a new kind, and wayang's becoming like a night market, are aspects of the complex interaction, and of wayang's being in the present world. 
126 Jan Mrázek

Wayang's being on the market involves not only the competition with other media, but also competition among dhalangs. Some dhalangs go bankrupt and others become very successful. The successful dhalangs today charge exorbitant fees, become extremely rich, and become interesting to people-even those who never watch wayang -as celebrities and as the object of gossip. Indonesian newspapers frequently feature articles about the private life of these "top dhalangs." The top dhalangs actively promote this image. Dhalangs like Anom, Manteb, Slenk, or Crazy Djoko arrive to performances in the most luxurious cars, and their "crew" (including the musicians) travels in less comfortable, but nonetheless very showy, busses and vans owned by the dhalangs. Big letters on the vehicles announce the name of the dhalang, the group, or their motto (See Figure 6, showing one of the two busses owned by Slenk). Before they put on their formal dress for the performance, the musicians and other people following the dhalang wear T-shirts, jackets, and caps advertising the dhalang, as well as the TV stations at which they have performed (typically Indosiar). The dhalangs wear heavy golden chains, live in huge houses that stand out like palaces in the villages and kampungs, own a great many cars (Manteb, for instance, has thirteen) and large collections of gamelan sets and wayang-puppet sets. There are various associations of fans of particular dhalangs, for instance, MFC-Manteb Fans Club ${ }^{46}$-and Manteb's fans are compared to the fans of Elvis Presley. ${ }^{47}$ In short, the top dhalangs are in some ways very much like other celebrities in the present world, such as pop music stars. This stardom, in its various manifestations, is an attraction in itself, and it is also appealing because it is associated with the modern, the foreign. In fact, Indonesian or English (and not only Javanese), are adopted naturally to underscore the foreignness of this phenomenon. Not only is, for instance, the name of the Manteb Fans Club in English, but so is the motto on the five or six new, identical vans transporting the musicians of Crazy Djoko's group: "The Best of Karawitan." On the "logo" of Warsena Slenk (which appears on his busses, stickers on his crew's motorcycles, Tshirts, and jackets), is written "SLENK Group" (see Figure 6); the word "group" is in English, and SLENK, a name given to him by one of his "fans clubs," is an abbreviation of the phrase Saya Lebih Enak Nonton Kamu, ("I like watching you more" [than other dhalangs?]), in Indonesian (not Javanese), the language of pop music fans.

When I was once watching a soap opera-sinetron-on TV, I objected that an actress's heavy make up, hairdo, and formal dress were in perfect condition even after she was raped and forced out of a speeding car. One person explained: "Niku rak wong sinetron" ("Don't you see, she is a sinetroner"). When a top dhalang arrives in a village in the newest model of BMW and displays his cellular phone (such phones in the cities are a new status symbol, but many Javanese villagers commonly see them only on TV), villagers must perceive him as another sinetroner, as a figure coming from the fairy land of BMWs and hand-phones as seen on TV. All the top dhalangs own and

46 See A. Komar Abbas and Seno Subro, Ki Manteb "Dalang Setan": Sebuah Tantangan (Surakarta: Yayasan Resi Tujuh Satu Surakarta, 1995), p. 109. MFC evokes KFC, the popularly used abbreviation for Kentucky Fried Chicken-an expensive and moderen eatery.

47 Ibid., p. 134. 


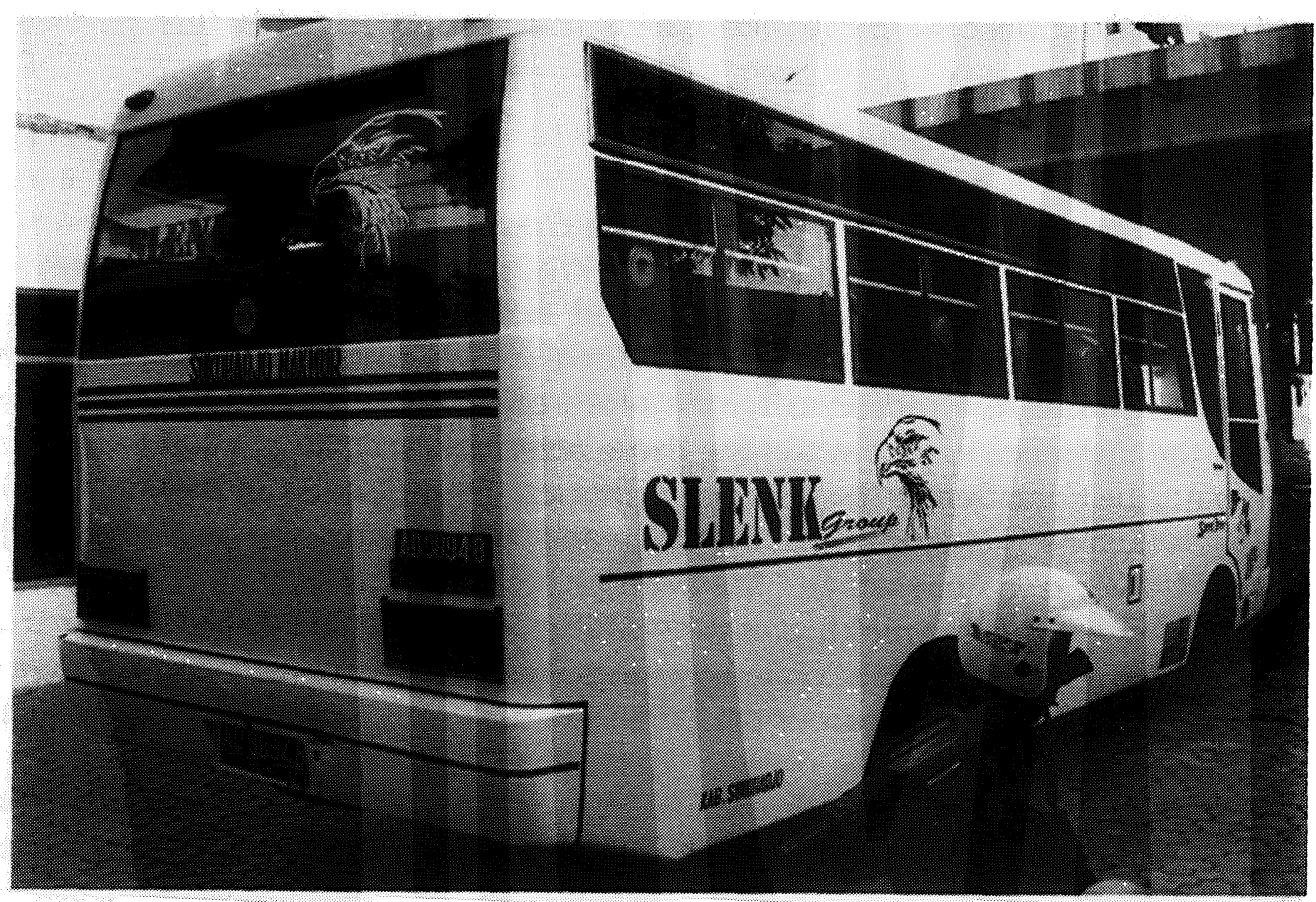

Figure 6. One of Slenk's busses, with SLENK group in big letters. When Slenk performs in villages, this bus is a part of the spectacle, overshadowed only by the spotless Mercedes-Benz in which the dhalang himself rides.

constantly display their hand phones. Like a pop music star, one aspect of the identity of the top dhalang is that he is just one of the celebrities who arrives from the world seen on TV and read about in magazines. And as I have mentioned, Manteb has also become famous as an "advertisement star," as have Crazy Djoko and other dhalangs, and other performers or "guest stars" who commonly appear in large-scale wayang performances, such as the comedians Yati Flatnose and Marwoto. ${ }^{48}$ Manthous and the pesindhen-star Anik Sunyahni have also performed in a sinetron. In any case, the image of a dhalang and other stars at the performance is at least to some extent like the image of a TV celebrity, and the dhalangs are in this sense among, in the midst of, the other popular celebrities. If the wayang performance coexists and interacts with other shows, the performers of wayang - the dhalang and the guest stars-and their images inhabit the same world as performers in other shows or media. When the performers appear in a spektakuler wayang performance that in some ways resembles a TV variety show, their image as popular celebrities, their being a little like sinetroners, is only enhanced. It has become common for people at a wayang performance to call the dhalang by his name, and he often does so himself when, during the clown scenes, he reads letters (requesting songs) addressed to himself. This explicit reference to the dhalang as Slenk, as Crazy Djoko, etc., rather than as Petruk or Cangik (a character), or at least as Pak Dhalang, and the explicit self-reference, is a reflection of the dhalang's new image as a celebrity, which differs from the more traditional image of the dhalang as dhalang, as somebody who has special powers because he is a dhalang, because he works the wayang medium and makes the puppets live. The puppets are not an essential part of

48 Cf. "Dari Lawak ke Bintang Iklan," Kedaulatan Rakyat, October 6, 1996. 
128 Jan Mrázek

the new image; they become more like curiosities associated with this particular celebrity.

This new image of the dhalang (it is not entirely new, but involves a significant shift in emphasis) as a TV-like celebrity, as a star, is not merely a matter of a new perception, but is in part created by the changing character of the performance and of the work of the dhalang and other performers. We have noted the various ways in which the dhalang's sovereignty is compromised, so that he becomes, increasingly, merely one of the performers, one of the stars. However, we have considered only what is visible to the audience. Traditionally, the work of making the performance is not hidden, and the audience enjoys watching those activities, watching what would in a Western theater be considered "backstage" activities. Traditionally in wayang there is no defined "backstage" separate from the stage and hidden from the audience. In the new wayang, however, a "backstage" has been created. By this I mean that a field of activities, of work, of theater-making, is now hidden from the audience, so that if we are studying the performance, it is no longer sufficient to consider only those activities visible to the audience. In addition to the (visible) guest stars with whom the dhalang has to collaborate, there are now people "backstage" who play significant roles in shaping the performance, who perform significant work-not merely executing dhalang's orders, but helping direct the performance. But neither they nor their workas work, rather than merely as product-are visible to the audience. Most of the top dhalangs today, for instance, read longer or shorter passages that have been written for them by other people. Let us look at one of the most popular dhalangs of the younger generation, Warsena Slenk, whom I have mentioned before. The Indonesian scholar Suratno, when concluding his inquiry into the "tricks" behind Slenk's popularity, mentions Slenk's production method as one of the "tricks":

One of the features of modern society is the existence of categorization according to the expertise of each person [this is true specifically about theatrical work in Java]. Warsena also uses such a division [of tasks]. He is supported by various parties in accordance with each person's expertise, for instance: B. Subono in matters of [musical] accompaniment; Jalena, Tunjung, and Memet in matters of blending gamelan and [Western] musik in play-songs [i.e., songs in the clown scenes]; and Sri Sadono as the resource person for lakon [the "plays": stories, plots, and other aspects of dramatization], as the script writer, and as a evaluator. 49

While in a traditional performance rehearsals are not essential, in Slenk's case much of the work goes on at rehearsals. Rehearsals are essential for a dhalang like Slenk, because his performances appeal by their newness. Slenk likes to perform the current hits heard on TV and radio, and those must be rehearsed and kept up to date. This is one part of the "backstage" work. Slenk's music advisors do much of this work, and much of the time Slenk merely looks on, or at the most he participates as one of the directors. Most parts are "precomposed" to a much greater extent than in traditional gamelan music, and the musician's task is to memorize and then play his part, rather than to create it. At performances, the audiences are presented with finished products (one reason for Slenk's success is that they are well-polished products), rather than

49 Suratno, Warsena Slenk, p. 93 
with the act of creation. Apart from the rehearsals, the "backstage" also exists at the performances, and it concerns all aspects of the performance music. After noting that Slenk has been voted "favorite dhalang" at a recent wayang festival/competition that involved fifty competitors, Suratno discussed the work that went on behind the visible action of Slenk's performances:

One reason for this success was that Warsena was supported by a script composed by Sri Sadono. Since then, Warsena has employed Sri Sadono as a script writer, and as the evaluator of his presentation. The evaluation concerns the following fields: puppet movement, udanegara [ethics/order], comedy, and the wholeness of the presentation. Usually the evaluation takes place on the way to or from the performance, or there is a special discussion at the dhalang's home. The task as a script writer [is performed] when at the time of the performance $k i$ dhalang is asked to perform a lakon that he does not know/understand at all, and then Sri Sadono functions as a resource person. He reveals the skeleton [the basic structure/order] of the lakon [play/story] and of the essential dialogues to Warsena Slenk, and when needed he composes the most important dialogues, such as the teachings [ ... ]. All this is done by Sri Sadono as the performance is in progress. For instance, when the dhalang performs the jejer [the first scene], Sri Sadono writes the dialogues for the next scene, and later this text is read by the dhalang in the performance [of the second scene], and so on. For his work, Sri Sadono receives payment equal to the wage of the pesindhen, about Rp.60,000.50

In addition to taking advantage of Sri Sadono's "backstage" work, Slenk, like other top dhalangs, carries with him an elegant briefcase containing scripts of plays and parts of plays from which he often reads during the performance. Some of these are published materials. Other texts are photocopied from scripts provided by other dhalangs. Some of it is by Sri Sadono. Other scripts come from another capable dhalang.

These examples should give a rough idea of the "backstage" work, of its importance in these performances, and of the importance of the invisible workers paid by the dhalang. The dhalang's task is different, too, compared to what it was traditionally. However, to the audience he still appears (to some extent at least) as a dhalang, as the person working, though this image may be less important now, in part because it is to some extent a mask. The dhalang is more like an actor acting the part of a dhalang; the work itself is more acted, less performed, than in the past, and the real work, the making of the performance, is hidden.

At times, this pretense leads to an embarrassment. For instance, at a performance I saw in 1997, Sri Sadono wrote a script of the narration describing the king's riches, including his elephants, and as usual, discreetly-unnoticed by the audience-gave it to Slenk to read at the performance. Slenk, like other young dhalangs, likes comedy in everything, and in this case, too, the text was made funny. In cultured, rich language, it described the king's elephants, and these descriptions cleverly and subtly alluded to the pesindhens present at the performance; each elephant represented a pesindhen and shared with her some significant features. As Slenk was reading, he could not control his laughter, and finally was not able to finish reading it and had to interpose a mood

50 Ibid., pp. 45-46. 
chant. The spectators either did not notice it or did not notice what had really happened, but the musicians, and perhaps more importantly, Sri Sadono and Slenk, knew. Sri Sadono had successfully accomplished what he was asked to do: his text was creative, clever, funny yet subtle, and as always, in a good wayang language. And precisely because it was so good, Slenk momentarily lost his control, he was disarmed by Sri Sadono's good work. The performance went on: Slenk was embarrassed, and Sri Sadono remained calm and invisible, with only a shade of a quiet smile on his face. And yet, this small incident demonstrated that Slenk's image as a dhalang is to some extent a pretense, that to some extent he is the actor, or the puppet, presenting a work that is not his own, that does not come out of him, a work to which he is not "organically connected" (to use the phrase we have been using about the relation between the puppeteer and the puppets). The authority of a dhalang like Slenk does not come from his work at the performance; performing as a dhalang, his authority itself is a pretense.

Older dhalangs say that a dhalang like Slenk (and the other most popular contemporary dhalangs) is not a dhalang, but rather a penyaji ("presenter," especially of entertainment): he merely presents the work of other people, or the products of work previously done, he presents scripts written by others, music chosen and written by others, and presents the guest stars and their various attractions. The dhalang of course still does some work, he still participates in creating the performance, so that to say that a dhalang like Slenk is merely a presenter may be exaggerated. However the comment does illuminate a general tendency: the increasingly important function of the dhalang as a presenter, as somebody who presents work which is not his own in the sense that he is not organically connected to it. It reflects that the dhalang is somewhat less than before a performer who derives his authority from his "organic bond" to his work, from being able to make the work his own, from his control of the making of the many aspects of the performance.

For example, older dhalangs often say that when the younger performers read, one can hear that the delivery does not krasa, does not "feel," that the emotions are not real. For instance, Pak Sutino was saying that when he narrates something that is sad, he feels really sad, and when something that is joyful, he feels full of joy. Pak Naryo was saying that it is good for a dhalang to go out to a forest or to see the sea, because when he narrates about these in wayang, the narration will krasa and the dhalang will be able to njiwani, to put his soul into the narration. Even though they use many formulaic expressions, the older dhalangs are able to make the narration very expressive because they have a more intimate relationship to the words which they utter, and this can be felt from their delivery; they are able to presence their own experiences and emotions through the words. The lack, or disintegration, of the dhalang's "organic bond" to his words is rather like the disintegration of the organic bond between the puppeteer and the puppets.

Critics also often say that the "presenters" have it easy: not only do they take a break when the singers sing and the comedians talk, but they also "take a break" in another way, since so many of the tasks that the dhalang traditionally performs are handled by people other than the presenter.

And yet, Slenk and dhalangs like him have attained power. Whence this power? From the market, from the audience, from the anonymous masses. These dhalangs are 
skillful presenters, they are able to package the performance, and that is what the market requires. They are up to date in different ways. They present what is currently popular. They understand the demand and do everything to satisfy it. Their work as presenters of attractions is rather like that of people selling wares at the market, or like TV producers or presenters. They are able to make money, and with their money they are able to buy various assets, including other dhalangs (like Sri Sadono) who write scripts for them and work "backstage," assistants paid by the dhalang-presenter. Even in performance, their authority derives from money. Slenk's musicians, for instance, say that Slenk does not understand music, and yet they follow him because he has and pays more money than other dhalangs. Thus, Slenk's authority in performance comes from outside of the performance, from Slenk's work outside the performance and from the market in the midst of which wayang is now. Slenk's success comes from his business ability to manage his "work force," to establish good relations with the sponsor (like all top dhalangs, he was a strong supporter of Golkar), and additionally, to present an image of himself as a dhalang, which is at least to some extent "acted." His image is a pretense in the sense that, like his performances, it has its "backstage": people like Sri Sadono, who to a great extent controls the work going on "backstage," or the other dhalangs and music-arrangers, are unknown even to Slenk's fans, and Slenk takes credit for their work, or rather the products of their work. Their centrality in performance, and Slenk's being a little like a puppet in the performance, is not reflected in the image. The work of the "production staff" is to a greater extent hidden behind the image, rather like in the case of TV, and what is sold is the dhalang, a TVlike star.

We can understand why older dhalangs see not only this image, but also the new performances with their "backstage," as a pretense that contrasts with the more traditional performance where the work is all displayed and where the one who appears in control is in control even in the performance, in the building up of the performance. At the same time, we can see that Slenk, and the other successful dhalangs, are merely adjusting the wayang performance to the present world, by making it marketable, by packaging it for the market. As wayang tries to profit from its interaction with, let us say, the TV, so it tries to profit from its interaction with the market, from opening itself to the market forces, to the audience. It tries to survive in the market, and it is very successful-even if what survives may be, to some extent, or for some people, a pretense, a fake, a packaging, a TV-like image, rather than a building-like work. But this is a pretense only in the sense that it does not expose the work behind the product, and this sort of camouflage or packaging is considered fair play at the market (I think it is called "building an image").

I have used Slenk as an example of a general tendency, and what I said about him does not apply to the same extent to all dhalangs. Manteb and Anom, for instance, have undeniably greater knowledge of wayang and music, and their performances and the divisions of labor that go into creating the performances are more like the traditional than Slenk's. However, the same general tendency toward "presenting" is apparent in their work: they, too, read frequently at the performance, they hire musicarrangers, and Anom pays a consultant, an old dhalang $X$ admired by Anom, who handles tasks similar to Sri Sadono's. As for Manteb, he is assisted by several people from the academy, and he uses the scripts of the old dhalang $X$ who helps Anom. Moreover, it should be obvious that these practices have developed from earlier 
132 Jan Mrázek

practices discussed above, and the tendencies discussed above, when I described performances by Slenk, are only further developments that have grown out of the increasing importance of music and songs, and of other performers apart from the dhalang.

Also, the cases of dhalangs like Anom and Manteb, who are undeniably skilled artists, show that it is the need to present their performances in the market, to package them, that makes the dhalangs change the performance technique; they do not make these changes because they are unable to handle the responsibilities of a more traditional dhalang. Many of the dhalangs who now read (such as Anom and Manteb) could perform a traditional performance without reading (and in the past they did), but the market's demand for the new and up-to-date forces them to be always new in a superficial and obvious way, for which purpose they hire other people to write innovative texts, and they hire music composers to compose and rehearse new pieces. (Manthous says: "I am indeed oriented to the market. [ . . . ] Among other things, [I have to] produce new forms, remembering that today people are very critical and always demand something new.") 51 Gradually, the traditional skills and techniques of the dhalang become less important because they are not marketable. What is important are the skills of the presenter. The dhalang, in his traditional role as dhalang, takes a break.

Note also that the dhalang's engagement in the market coexists with his involvement in politics, and in both cases his major motivation and goal is the sameto survive, and, if possible, to be successful. When Manteb sponsored a performance by Crazy Djoko in his house, and he was reflecting on Crazy Joko's innovations and popularity, he said, only half in joke: "In my view it is very good that Djoko is successful, that he is in demand; for if not, Djoko might have to become a thief, and his musicians beggars." Similarly, the dhalang's involvement in politics is a part of his endeavor to provide for himself and his musicians, and to be able to do so as a dhalang, rather than, say, a thief. I am reminded of the Iranian picture showman: "Should a constable come to harass him, he will immediately begin to sing praises of the sheriff who is painted on the right corner [of the narrative painting] for just this purpose." 52 Dhalangs' involvement with the government and with the expanding market in Indonesia might not be quite equivalent with the showman's technique, but in some respects they resemble each other.

One Direction, One Loose End: The Possible Future of Wayang as a Part of its Present, and Professor Siegel's Theory of American Beer

In August 1996, Indosiar, the private TV network that broadcasts weekly wayangs, sponsored a large-scale show in Surabaya, called Pesta gado-gado Indosiar. Pesta means "party, festivity, celebration." Gado-gado is a term we have encountered previously. It means "mixed salad, potpourri, a mix of diverse elements." The show featured famous Indonesian pop music and rock singers, set against the backdrop of a gigantic wayang

51 "Campur Sari Bakal Jadi Musik Indonesia," Kedaulatan Rakyat, August 17, 1996

52 Victor Mair, Painting and Performance: Chinese Picture Recitation and its Indian Genesis (Honolulu: University of Hawaii Press, 1988), p. 120. 
screen. Spectacular moving colored lights were "played" on the screen and the space around it as the pop music stars sang, and tens of thousands of spectators watched. Soon after midnight, a short-slightly over three-hour-wayang performance began. The dhalang was a junior high school student from Solo, Mohammad Pamungkas Prasetyo Bayu Aji (or Bayu, for short), the youngest son of the famous Solonese dhalang, Anom Suroto. A newspaper reported:

Previously the organizers indeed worried that the thousands of spectators who filled the square would disperse when the performance of musik was over, at about 12.45 [am]. It was feared that the wayang kulit performance which featured the duet [duet] [consisting of] Bayu and the comedian Kirun, who were to appear after the musik show, would be abandoned by the spectators [ditinggal penonton]. But the fears turned out not to be justified. The Surabaya spectators, who are indeed well acquainted with Bayu-because he often appears with his father [Anom] when performing in Surabaya-remained waiting for the appearance of the dhalang. The little venerable dhalang [ki dhalang cilik], who performed the story "The Death of Kumbokarno," [Kumbokarno is a big ogre] immediately began with a flashback scene [flashback in English and italicized in the original], [showing the time] when Anoman was burned when he was the ambassador of King Ramawijaya. Of course, Bayu, who is very skilled at sabetan [puppet movement/acrobatics], immediately received an aplaus ["applause," in italics in the original]. The scene contained the fight between Hanoman and the army of Alengka. After that, he handsomely performed [the first part of] the lakon which was condensed into about one hour. At the gara-gara scene, his [Bayu's] place was taken by Kirun [the comedian], who appeared a little groggy. "It turns out that dhalang-ing is not easy; I was groggy, so my jokes were not flowing freely." But, finally, Kirun, who was playing the puppets "as well as he could," was able to make the spectators sway with laughter, especially when his two colleagues, [comedians] Bagyo and Kholik, and "surprise" pesindhen [and comedian] Mia from Sri Mulat Surabaya, joined in. Kirun was showing the garagara for about one hour, [after which] Bayu continued the performance until before the subuh [the morning prayer, about $4.15 \mathrm{am}$; that is, Bayu was performing for about an hour after the gara-gara]. Without feeling [the time], the mesmerized spectators were not aware that the wayang was already over. They did not get up from their places. Only when the musicians and the dhalang left, did the audience also disperse. ${ }^{53}$

One could categorize this event as a pop music (musik) concert, separate from the wayang tradition. Its name, Pesta gado-gado Indosiar, certainly identifies it as a potpourri show sponsored by a major TV network, or even as a kind of TV production at which wayang is present only as a diversion, one of many attractions. Yet one would also be justified in considering this entire event a modern wayang performance. Not only the presence of wayang at this event invites us to consider it a wayang performance; there's also the fact that this event has so much in common with other, more typical performances going on today, especially the spektakuler, kolosal wayangs, and that it is less an exception than a variation in the current trend. The various tendencies characterizing other wayang performances today, tendencies apparent in

53 Joko Dwi Hastanto, “Bayu, Bintang Pesta Gado-gado Indosiar," Suara Merdeka, August 20, 1996. 
134 Jan Mrázek

the historical development of wayang for some time, have been taken a step furtheryet another step.

The attractions that were staged after 12:45 am are by now familiar. First, the audience witnessed plenty of spectacular sabetan, especially fighting, for the young dhalang, little Bayu, a student of Manteb's, is even more dexterous than Manteb or any other dhalang in performing spectacular acrobatics with the puppets. His movements are even faster and more flashy. Next to Bayu's sabetan, Manteb's sabetan feels like an old dhalang's; it is less dexterous, less flashy, but it does have more force, is more physical, "feels" (krasa). It is hard to blame Bayu for failing to "presence" physical strength in this way at his age. In fact, at his age and with his skills and his modest but self-confident bearing, it is hard to blame him for anything; audiences are mesmerized by his skill and appearance, and school girls begin to be seriously interested in wayang (he now often replaces his father, Anom, as puppeteer for the battle scenes in Anom's performances, as seen in Figure 7). In addition to the kungfu-like sabetan, Bayu made the performance interesting by using flashbacks, a storytelling technique associated with films. The gara-gara clown scene took about one third of the short performance, and a comedian, rather than a dhalang, moved the puppets (yet another sign that the distinction between dhalangs and comedians is often unclear). He was assisted by other comedians and a pesindhen-comedian from Sri Mulat-in this way, too, the performance manifested a significant tendency in the development of the performance. Note that in the quotation above the dhalang and the comedian are said to form a duet. Another newspaper reported-incorrectly, but tellingly-that the dhalang was Kirun (the comedian) and the wayang "presented the play Goro-Goro" (menggelar lakon GoroGoro). ${ }^{54}$ In other words, this reporter perceived the whole performance as a clown scene, and the comedian Kirun as the dhalang. The comparatively short length of this

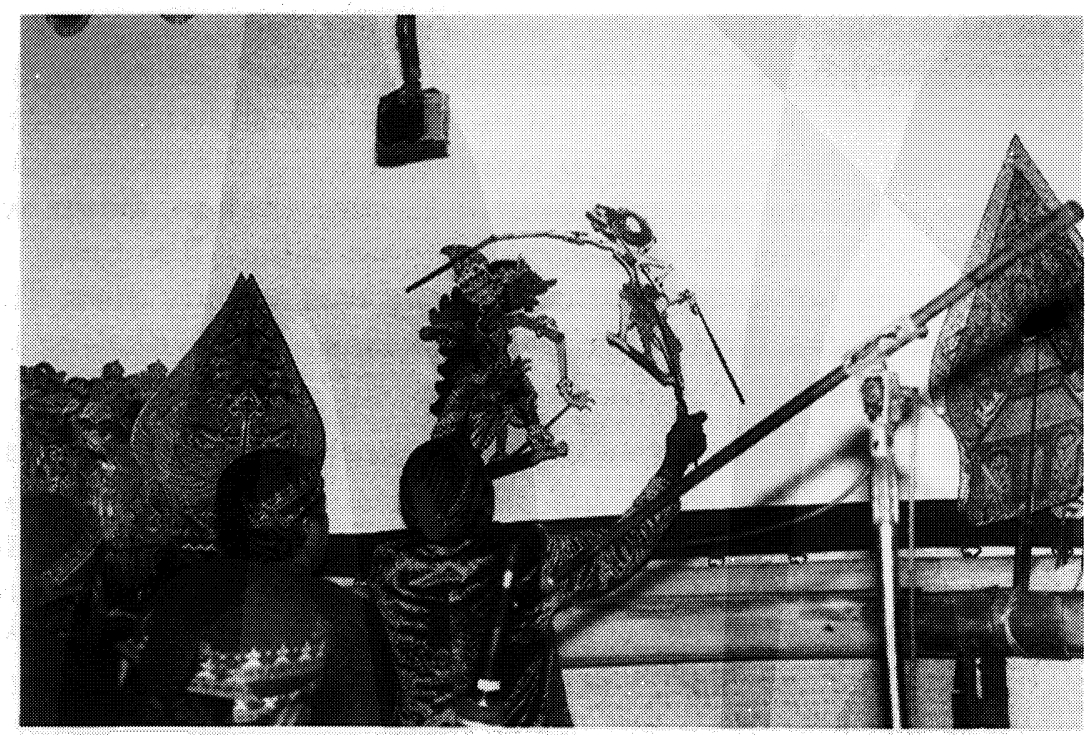

Figure 7. Bayu, famous for his new-style, kung-fu-movie-like, acrobatic puppet movements, is showing off.

54 "Artis Beken Tampil dalam 'Pesta Gado-Gado" Indosiar," Jawa Pos, August 12, 1996. 
wayang performance also followed a current trend. ${ }^{55}$ While traditional performances in the seventies lasted until 5:30 or even close to $6 \mathrm{am}$, in 1990 and 1991 the experimental colossal performances lasted only five to six hours, and were over at about 2 am. Today, most performances by the younger top dhalangs end commonly sometime between 3 and 4 am, and occasionally as early as 2 am, while older dhalangs conclude a little later, but still earlier than in the past (to end sometime between 4:00 and 5:30 is common for a relatively traditional performance today). 56 Thus, in its duration, too, this show only moved a step further in a direction that wayang performances have been heading for a long time.

Finally, and most importantly, we should consider the whole of the performance. It was a "pesta gado-gado," a potpourri festivity. On the one hand, this is clearly a manifestation of the "mixedness," the gado-gado-ness, that I have discussed throughout this essay as a fundamental characteristic of the current developments, apparent in various areas of the performance (the common inclusion of pop singers and comedians in wayang performances being only one example). Thus, everything seems to fit-the performance was new in the ways that we have shown wayang performances are becoming new. And yet, it is precisely because the performance fits so well in the "tradition" of wayang's contemporary innovations, because it has evolved so exactly in the direction that we have described, because its newness is merely another step, and not even a leap, that what is obviously different about this show is so significant, and so striking in its significance: the performance was essentially like other wayang performances today, it was "just another wayang performance," except in one respect, except in one "detail": as a whole, the event was not a wayang performance, but rather a "pesta gado-gado."

What happened? One can tell from the headlines of the article reporting on the event in a Central Javanese newspaper: Bayu, Bintang Pesta gado-gado Indosiar, "Bayu, the Star of the Indosiar Potpourri Celebration/Show." That is: the puppeteer, with his puppets, became a guest star at a larger show. What is striking is that such a small step was enough to alter a wayang performance so that it ceased to be a wayang performance.

Seen in a historical perspective (which offers an interestingly limited focus) all the innovations discussed in this essay - the mixedness, the inclusion of other genres and other stars, the dhalang becoming only one of the stars, the kolosal-ness and the spektakuler-ness, the wayang performance being like a pasar malam-seem to have led to this. These developments have advanced so far that now one cannot say that various foreign elements are being mixed into wayang, for in certain cases wayang has become an ingredient mixed into a larger show. Where wayang once incorporated other genres or media and guest stars, now it has been incorporated as one of the genres or media and the dhalang has become a guest star himself among other guest stars. Where wayang once used various means to become kolosal and spektakuler, now it has become a means to make a kolosal show even more spektakuler. Instead of being like the center generating a pasar malam, it has become one of the attractions at a television variety

55 Cf. Helen Pausacker, Behind the Shadows, pp. 31-34.

${ }^{56}$ Here I am speaking about performances "at large," rather than various short experimental performances at the Art Academies. 
136 Jan Mrázek

show, at a new kind of pasar-malam-like event. On the one hand, wayang has been bought by a larger show which was, ominously, sponsored by a TV company. On the other hand, taking into account the direction of the developments in wayang, and how this one little step was sufficient to change the identity, the definition, of a performance, this has to be seen also as a development of wayang: in this particular case, wayang performance has grown to such a size that it got lost in itself, it has lost itself in its own kolosal-ness and spektakuler-ness. Wayang has grown into such a large and varied show that the overall size, form, and structure of the show is no longer recognized as wayang, and wayang is only a "guest star" in it.

This performance is only one example of such a case, and there are many others different in the degree and manner in which they are and are not wayang. When one show in 1996 is advertised in a newspaper by the promise "50 Female Singers Will Appear in Sukoharjo," the advertisement suggests that while this show is a wayang, information about this other attraction, the fifty pesindhens, is more essential to describe what is going to take place. The fifty pesindhens were judged to be the attraction of the evening, more important than the dhalang and the puppets. .57

We have seen how the clown scenes have grown in importance and in length, and how the characteristics of the clown scenes, especially an opening to the interaction with the present, has become characteristic of the wayang performance as a whole. In the Pesta gado-gado Indosiar, one could say, the clown scenes have overgrown the other parts of the performance, so that rather than the clown scenes being incorporated into the structure of the wayang performance, the wayang performance has become a part, only one attraction, of a super-clown-scene.

This is not merely a matter of internal relationships. The newspaper article reports:

Bayu can be indeed called a star of the Pesta gado-gado Indosiar which took place last Saturday during the whole night. He could prove that wayang kulit can in reality stand next to other modern arts such as musik rock and dangdut. .8

That is: the wayang medium has become merely one of the attractions (and clearly a successful attraction), next to rock and dangdut, at a colossal event sponsored by a TV company. Further, the text asserts that wayang kulit in general can "stand next to" the other attractions in the present world, in the same way that it was seen next to them at the pesta gado-gado. In this sense, the present world is like a pesta gado-gado, and the wayang medium is in the world like an attraction in a "putrid pot" of attractions, a pesta gado-gado, positioned next to rock and dangdut.

This way of being in the world reminds us to look again at the sponsor: Indosiar TV network. I want to suggest that this way of being in the world is a way of being on TV. I have shown that what has been called the "marriage" of wayang and TV is in some respects similar to the "marriage" between the keyboard and gamelan, and here I want to point out one more similarity. In the same way that the keyboard-a favorite instrument of Manthous-has no voice of its own but has the voice "of" the violin or saron or other instrument, and that it is pure reproduction displayed before an audience, so TV, in the way it presents wayang, has no "voice" of its own, but it shows

57 “50 Waranggana Akan Tampil di Sukohardjo," Suara Merdeka, June 25, 1996.

58 Joko Dwi Hastanto, "Bayu, Bintang Pesta Gado-gado Indosiar." 
electronically reproduced images of something else. In the same way that the keyboard "has power over the sound" of Campursari in spite of, or rather because, it has no voice of its own, so TV does not disappear, but "has power over" the images it presents: they are essentially TV images, and in its various marriages-including its marriage with wayang-TV transforms the "partner" radically, at the same time that it presents it as "wayang." If Manthous with his keyboard "plays with sampling," the TV producers, similarly, present "samples" of other shows, and this presenting of "samples" characterizes TV. The pesta gado-gado is essentially like TV in the sense that it also presents disconnected samples. The wayang's voice in the clown scenes-the voices of the wayangs, the puppet/characters-has become only a sample among other samples.

Most of the pesta gado-gado was broadcast on TV and at the same time seen live. In the same way that, as I have shown, wayang performances seen live are affected by wayang's marriage with TV, so the live show was essentially a TV program seen live; or a live show that is a product of TV and is sponsored and organized by a TV company.

We have seen that wayang's being at the pesta gado-gado is analogous to wayang's being in the world, the world being like the pesta gado-gado. If pesta gado-gado is a product of TV, and is essentially a TV program seen live, this is true-at least sometime, at least in some ways - about the present world: it too is "married" to TV and the world's being like a pesta gado-gado is a product of this "marriage." That is, the present world is affected by its "marriage" to TV no less radically, and rather in the same way, that wayang is. What is relevant here is that if wayang is in the present world in a similar way that it is in the TV-like pesta gado-gado, this suggests that wayang is in the present world in a similar way that it is on TV-as a sample of wayang, an image of itself, a "deputy" or "representative" (wakil) of itself, as one of the attractions positioned next to rock and dangdut in a loosely connected clownscene-like world that is a medley of attractions. The separate parts of the medley, of gado-gado, as we have seen, do not ask to be connected (or "tuned") together, but remain separate, like attractions at a night market. Or at least, this is one aspect of how wayang is in the world. ${ }^{59}$

Two days after the pesta gado-gado, there was a performance in Solo. A newspaper announces it:

Differently from previous years, the reception of the Regional Government Solo commemorating the 51st anniversary of the Birthday (BD) [Hari Ulang Tahun (HUT)] of RI's Independence, which is usually cheered up by an all-night wayang kulit performance, will this year be celebrated with dangdut music and keroncong. [The functionaries] explained to the journalists that originally there indeed [was a plan to] have a performance of wayang kulit like in the past. However, later a change was made to give a different nuance [nuansa] . . 60

In the pesta gado-gado in Surabaya, wayang was incorporated as one of the attractions, but it could have been excluded, and the character of the event would not be much

\footnotetext{
${ }^{59}$ In a planned book focusing on the interaction of wayang and TV, I hope to present a more nuanced description.

60 "Pemda Peringati Kemerdekaan dengan Dangdutan," Kedaulatan Rakyat, August 16, 1996.
} 
138 Jan Mrázek

changed; there would be only one attraction less, and it could be replaced by another. The event in Solo was in many ways like the pesta gado-gado, though on a somewhat smaller scale. Here, too, various pop singers were singing, and the musical genres were varied (there was kroncong, dangdut, as well as pop Indonesia). The only difference was that there was no wayang. In previous years, there was a wayang (a large scale wayang, with many non-wayang attractions); the absence of wayang, the sponsors said, was a matter of "nuance." The performance in Surabaya could be seen as a direct development from other new wayangs; the performance in Solo is the next step, and in this sense it is a part of wayang development. It is not even a step forward, but rather aside, according to the functionaries quoted above; the difference between it and the wayang performance of last year is a matter of "nuance." In other words, if we follow the history of the developments, we can not only say that the performance in Solo "replaced" a possible wayang performance; we can also say that wayang has developed into an event in which wayang is not essential (as in Surabaya) or absent (as in Solo).

If people-Indonesian as well as Western observers-fear that wayang will become "dead," will become closed off from the present world and ditinggal penonton (abandoned by the audience), that it will become a matter of the past, our inquiry suggests another scenario for the disappearance of wayang. It will-in certain performances-become so open to the present that it might lose itself in the present, overwhelmed by it, incorporating anything that is currently popular, loved by the spectators, devoured by the consumers, by the market-perhaps rather like TV. As we have seen in the newspaper reports quoted above, people will not even call it wayang.

Once upon a time I asked Professor Siegel, as we were drinking good Czech beer, why in America what people think of as "beer" does not deserve to be called beer. He answered that it is because there already is something else called "beer." When people will call a performance "wayang," there will be-or rather are-others saying that this is not wayang (but rather pasar malam, or pesta gado-gado, for instance), or that this is not a dhalang, but only a disc-jockey-like presenter. People will not agree on the meaning of words. That would be a curious ending.

A metaphor used by Ki Soegito Poerbotjarito, a respected dhalang from the Banyumas region, comes very close to our terms, when he reacts to the common statement that the various innovations and attractions are merely "spices," and that the basic structure is not changed (for instance, Manteb says: "My attractions [atraksi sayal are only spices, so that the audience would be attracted to watch"). ${ }^{61}$ Responding to this idea, Soegito says:

As long as [it makes wayang] sell well, all foreign [asing] elements are put in. As long as it sells well, all spices are allowed. It should not be that way. When spinach is cooked, the taste of spinach should emerge. A gule should not taste like beefsteak [bestik], and so on. ${ }^{62}$

Is meat for gule cooked like a steak still a gule? It is and it is not.

61 Quoted in Apa E Siapa Orang Jawa, Edisi 1995-1996 (Semarang: Citra Almamater, 1995-96), p. 229.

62 "Ki Soegito Poerbotjarito: Pemberontak Budaya yang Kesepian," Suara Merdeka, October 23, 1997. 


\section{Final Thoughts. The Limits of this Essay, of Clown Scenes, of Innovation: The Wayang Performance as (a) Building}

Is this the future? I am not interested in what happens next year or in ten years; rather, this is the future as a force, a presence, in the present world . . . what has been described has been happening. On numerous occasions, wayang has disappeared, "fallen apart" (bubrah), as some say. This happened in the two performances I have described last in the essay, and no doubt it will continue to do so-it does so at every performance, whenever a pop singer stands up and the dhalang takes a break. Many people enjoy this; critics say that this collapse is a reflection of the times. One Javanese-who says that in wayang performances today "from the first audience scene to the tanceb kayon [the end], there is only comedy [anane mung dhagelan]," and that (as a dhalang) "if you want to sell well, you have to become a clown [yen kepengin payu iku ya kudu ndhagel]"-puts it thus:

The wayang performance [pakeliran: "screen-ing"] is indeed a picturing of the world [gegambaraning jagad]. Therefore if wayang today is said to be broken, perhaps the being/condition of the present world is like that too. ${ }^{63}$

And yet, this is not all that is happening. Wayang is not only "broken." That is only a part of the story. At this point, I wish to say more about the limits of this essay.

At the same time that the "extreme" events described in the previous sectionperformances situated at the far edge on the spectrum of wayang development-do take place, many other wayang performances also take place. They show more or less innovation and openness to the world. This is true of performances staged by different kinds of dhalangs, from the youngest dhalangs who present large-scale performances in which the dhalang and the puppets still play a significant role, to popular dhalangs like Manteb or Anom who present slightly more traditional performances, to older dhalangs in the villages who incorporate some of the innovations but limit them to a great extent. And if I said that wayang falls apart in every performance, it is also true that much of what makes wayang wayang is present even in some of the most "revolutionary" performances. Interestingly, when wayang becomes too different from what people are used to, it tends to have an extremely limited audience and lifetime; this was true of the wayang experiments in art academies. The history of innovation, too, is continuous and changeable, and wayang was said to be disappearing even many decades agoNartosabdho in the sixties was said to have gone "too far," and he was known as the "crazy dhalang," as are younger dhalangs today. In 1965, Ben Anderson pointed out tendencies in wayang's development that resonate with criticisms of contemporary wayang:

The reduction of wayang's formal structure into a series of battle-scenes linked by banal jokes and sentimental boudoir interludes. Here the influence of the cinema is unmistakable, since fighting, comedy, and sentiment are the essentials of most films that Indonesians see. The current pressure to shorten a wayang performance

${ }^{63}$ Quoted in "Pedhalangan Wis Rusak," Mekar Sari, September 6, 1996. 
140 Jan Mrázek

from a whole night to two or three hours reflects again the assimilation of wayang to modern commercial entertainment. ${ }^{64}$

Thus, how does wayang exist, at the same time that it keeps dissolving in the present world?

In wayang performances, people come and go, talk, go to have a snack, or sleep during a part of the performance. Very few people stay until the very end when the gunungan puppet is planted at the center of the screen, and it is hard to come late to a wayang because either one comes as a guest before the performance starts, and sees the performance only as continuation of the larger event, or one comes after "everything" has started anyway. Different people have different ideas about when the performance starts; some want to come early to hear the music and the calm first scene, others come only later when the story moves forward, or to watch the clown scenes. Today, many people watch until about 2 or 3 am. In more traditional performances that extend well beyond those hours, many people leave without seeing the end, but there are also people who arrive later in the performance. In the past, old dhalangs say, there were usually more people in the audience in the early morning than is generally true today, not only because more would stay longer, but rather because more people would come at that time. The wayang performance is there, and people come and go.

I have discussed elsewhere how the wayang performance is integrated into an architectural space (a house or a temporary structure), rather like narrative reliefs are integrated into ancient Javanese architecture; how the performance, like the reliefs, is a part of the architecture. ${ }^{65}$ In my dissertation, which I evoke here in order to give a better idea of the limits of this essay, I have elucidated wayang as a work in progress, and as work that has a structure, as (a) building-building as a working process, and building as something that stands by itself, not in the sense that it would be static, but rather in the sense that it is built up in such a way that it holds together. As a work that has a coherent structure, the way that the performance is in the world is to some extent independent of the audience, like (a) building. It defines and "decorates" (which means also to "confer distinction upon") ${ }^{66}$ space and time, but one does not have to see every detail, not even the key parts of it. What is important is that it stands there, like a building, holding together and up. People relate to it like to a building. They are in its space, they walk through it, ignore it sometimes or are touched by it, feel various things about it, write about it, and never see everything at once. The performance, like the building, is there, the work goes on, whether there is an audience or not.

One reason why a person sponsors a performance is to attract people. But the performance is put up like any other decoration, like a temporary building. Once it is there, it is not considered a great scandal if people do not stay till the end. It is hoped they will appreciate it as something that is there, as a building, or as the other

\footnotetext{
64 Benedict R. O'G. Anderson, Mythology and the Tolerance of the Javanese (Ithaca, NY: Cornell Modern Indonesia Project, 1965), p. 27.

65 Mrázek, "Phenomenology of a Puppet Theater," Chapter Seven.

66 Webster's Encyclopedic Unabridged Dictionary of the English Language (New York and Avenel: Gramercy Books, 1996), p. 519.
} 
decorations. They may be disappointed by it, or they may find it impressive and to their liking, but in any case they can choose to "leave it there."

The performers build up the structure not according to their whim-they could not do that even if they wanted. Rather, they build up the performance as a structure that has to hold together; they build it with this final and original coherence of the structure in mind, with respect to it, and their freedom and their ability to build the performance always anew, always differently, and yet in such a way that it is coherent as a structure, derives from their knowledge of the work, from their practical knowledge of the principles of building up a coherent wayang performance.

In his book on the Indian shadow puppet theater, Inside a Drama House, Stuart Blackburn describes how, after being prepared by current Western scholarship for studying the all-important audience, when he arrived in India he realized that the audience was not there. ${ }^{67} \mathrm{He}$ suggests that "the performers are performing for themselves," 68 the performers being "inside a drama house" and separated from the audience, and he speaks of the performance as an "internal dialogue." 69 Though (as Blackburn also mentions) this view of performance does not fit the current interest in the role of the audience, but is rather based on the observation of reality, and the Indian shadow puppet theater is different from Javanese wayang, Blackburn's terms basically agree with my conclusion that wayang is as (a) building, or at least this is one aspect, one quality, of wayang. A Javanese writer on wayang comes to conclusions that resemble Blackburn's observations:

In a performance that is Western in character and has the soul of democratic politics, the audience cannot come and go and chat during the performance. The attention of the audience needs to be concentrated on what is presented, and on the people who execute the performance. And at the end of the performance, the actors all appear together to accept bouquets of flowers and applause. Westernstyle performance requires "duty to watch and pay attention, appreciate, and if possible, praise." In a wayang performance, this is not necessary. Depending on the dhalang's art, the audience will be fixed in place [terpaku, lit. "nailed" in place] or not [applause itself is a new and still rare phenomenon in wayang]. And in all my experiences, the dhalang never gets angry because he is not given attention. In my view, being a man of the past, [in] the atmosphere [at wayang, wayang] is not a "performance" [in English and in quotation marks in the original: meaning Western style performance], not something that has to be watched. The dhalang and the gamelan musicians "play for the satisfaction of their own selves," and the "wayang-ing" is "play-ing." Watched or not-that is not a problem for the dhalang. This is, I feel, the essence of the atmosphere of wayang performance: that wayang is not a [Western style] "performance" that has to be watched, but a self-sufficient art [seni mandiri]. ${ }^{70}$

\footnotetext{
67 Stuart Blackburn, Inside the Drama House: Rama Stories and Shadow Puppets in South India (Berkeley: University of California Press, 1996).

68 Ibid., p. 12.

69 Ibid., p. 14.

70 Prof. Slamet Imam Santosa, "Pendapat Seorang Awam-Penonton Tentang Wayangan dan Wayang

Purwa," Gatra, No. 8, 1985, p. 15. It could be argued that even traditionally the dhalang and the musicians
} 
142 Jan Mrázek

Where is the audience? Blackburn writes that the audience is "textualized," "inscribed in the text,"71 and this applies at least generally to wayang. The people present are a part of the event, of the performance, and what is happening on the screen mirrors them, represents them-as human beings. Wayang performance is not a "construct" of its viewers independent of the presented work, but rather it has the potential of bringing the people into the building, into the work. The work that is wayang performance is open to the people present, and by its openness it brings them into itself, it enables the people present to participate in the work. Again, like the performers, they have to work with respect to the building; their goal is to be able to perceive the work as one perceives a building when one walks around and in it, looks at it from various angles, and tries to "get a feeling" for the building as a whole. The wayang performance is for human beings, like a building, such as a house, is open to people, and its potential is realized when it provides a dwelling for people; but the building nonetheless stands there on its own, even when at a particular moment no one is around, and as in the case a wayang performance, this coming and going of people does not make the building disappear. And like a dwelling, the wayang performance is never only an austere structure, it does not only stand up, hold together, and represent people. It can be embellished and decorated in various ways. It is made appealing in various ways, it is made pleasant. Thus, the "textualization of audience" is a kind of openness to people, a potential of the performance that people may or may not realize by coming into the building and participating in the work.

Blackburn writes that "listening to performance feels like reading a book."72 This, in the case of wayang, would be a dangerous analogy, because so many studies of wayang do not see the performance and its work and treat wayang as if it were "literature." However, saying that wayang is like a book is true in the sense that the book, as a work, exists without being read, that it has an identity that is to some extent independent from reading: reading is merely the realization of its potential, but reading does not create the book, in the same way that a person living in a dwelling does not thereby build it, but only realizes its potential.

It is because of this building-like quality of wayang that wayang is always more than what any single person can see, that its identity is not merely what is seen (this is true to a greater extent than in some other performances), that it requires a study that is not limited to "what is seen" and "what is understood." This is also why any study, like any spectator's view, is bound to be "partial," and why there are so many "partial" representations (interpretations) of wayang. Wayang does not merely mean; before that, it is, it holds up like a building.

In my dissertation I have discussed the various elements of the structure, and I elucidated the principles that govern the process of building the structure and the way that the building is open to people and people open to it. That is, in my dissertation, also, I questioned how the various elements and the structure as a whole are in the

do not simply "play for the satisfaction of their own selves," but work primarily for a fee; but this would be a very limited view. As far as they work, they work for the sake of the work itself, especially when, as in wayang, the performers are organically connected to their work and make it their own.

71 Blackburn, Inside the Drama House, p. 14.

72 Ibid., p. 14. 
present world. Here, as I said, the perspective of my dissertation can serve to give a better idea of the limits of this essay. How does what has been said in the present text fit with that perspective?

The distinction is not historical, and it would be grossly wrong to see the basic performance elements and the coherent structure as simply relics from the past. I wish to emphasize again that the basic elements of the building-like performance are equally present in the present world as the elements of more innovative wayang that occupy this essay, and they too continue to develop. A short anecdote demonstrates this point. In August 1997, I attended a performance in Solo in which an old dhalang was performing. It was what we might call a relatively traditional performance; it included only gamelan instruments and gamelan music, no performers standing up; the first clown scene took only about five minutes and there were no songs, and the second clown scene was also relatively short and only the characters spoke. A little before 3 am, when I would have expected the performance to continue for at least two more hours (judging from where the dhalang has got so far) electricity in the whole city of Solo went down. At first, the dhalang had the musicians continue playing music, so that at least the musical continuity of the performance would not be interrupted. After about fifteen more minutes of repetitive music, the dhalang put the gunungan in the center and stopped the music. The musicians as well as the few dozen people that formed the audience waited. When after another hour or so the electricity was still out, the dhalang and the performers, and after them the audience, left quietly, leaving the performance unfinished (only one musician remained sleeping with his head on his instrument; the other musicians made sure not to wake him up). Thus, even a traditional performance today is dependent on electricity that provides light and powers the sound system. Nobody thought about looking for and lighting up an oil lamp-indeed, that would have been going too far back. The microphone, too, seems indispensable these days even in a very traditional performance: even gamelan, for instance, has developed in such a way and to such a size that it would be difficult for the dhalang to work without the microphone. Thus, when I speak of a traditional performance or of wayang as (a) building, I mean something that is thoroughly in the present, is dependent on various developments in the present world (such as electricity), indeed is built up in such a way that it would not hold together without (for instance) electricity. What I mean by traditional, and that the traditional is imbedded in the present, must be kept in mind to understand this discussion correctly.

In asking how the traditional, basic elements fit with what has been described in this essay, we are not dealing with a simple distinction between the old and the new. What has been described in this essay is a way of being that is unlike the building-like way of being, and sometimes conflicts with it. Wayang faces a dilemma: how to be in the world?

In this essay, I have described certain aspects of the performance, most importantly the particular kind of opening of the structure to the interaction with the present world, with the foreign in the present world, which is most apparent in the clown scenes, but which penetrates other parts of the performance as well. This particular aspect, a kind of structureless "hole" in the structure that is usually framed by the structure, has developed in some performances in such a way that it threatens to break the frame, the wayang performance as a structure. It threatens its 
144 Jan Mrázek

cohesiveness, and its ability to stand on its own, or as the Javanese writer quoted above puts it, to be a "self-sufficient art," which he contrasts to what he sees as a "Western" performance that has to be watched.

Today this kind of opening is a part of all performances (and probably it has always been); only, while in some performances it is merely one aspect of the entire show, in others it becomes overwhelming. In this essay I describe a part of wayang, even an essential part, but if what is not described here ceases to exist entirely, if the self-sufficiency of the structure becomes overwhelmed by the structureless opening, wayang becomes a pesta gado-gado: one big clown scene, a potpourri of attractions. Some people are thankful that in the midst of this, at least something remains. The author of a newspaper article entitled "Fortunately Wayang Kulit Still Is" writes:

A person who has an accident and breaks his left arm can say, "Fortunately it was not the right arm." Or when his head has a serious injury, he can still say, "Fortunately I don't have brain concussion." Even when his house burns down, he can still say, "Fortunately the things could be saved." And so forth. So, when the wayang kulit performance has almost disappeared under the pressure of foreign culture, we can still be thankful and say, "Fortunately there are still young dhalangs," with young kids as spectators. There is something good, too, about our ability to say "fortunately" in all kinds of situation. Yet the word "fortunately" is meant to have connotations that make us concerned. ${ }^{73}$

But I, unlike most Javanese observers, do not say and do not question whether the developments are good or bad. I am saying that the coherent structure of wayang performance is of a somewhat different nature than a potpourri of attractions, and it is in the world differently. The conflict in the discussions today about what wayang is and what it should be reflects the conflict that is a part of the performance, it reflects the dilemma inherent in the performance. In the performance, the conflict is not simply between innovation and structure or between the clown scenes and the structure, because the structure has the potential to accommodate the clown scene, and to accommodate a certain degree of structurelessness, and a certain degree of independence and separateness among and between wayang's attractions (battle scenes, jokes, occasional non-dramatic music, etc.). Rather, the conflict characterizing performances today is between, on the one hand, the structure and its cohesiveness, and on the other, the expansion of the clown scenes and the innovation going "too far."

It is in this way that wayang is "broken" or "collapsing" (rusak, bubrah) as some Javanese put it, and this "breaking down" is also one of the things that makes the performances exciting. There is a particular pleasure and excitement in seeing the structure of wayang performance collapse-it often makes the performance very "lively."

When the self-sufficiency of the structure collapses, it becomes unclear whether the performance is still wayang. For instance, in my dissertation, I discuss one of the central features of wayang, the organic bond of the puppet and the puppeteer: in Chapter One, I show that an essential quality of the puppet is that it is a good

${ }^{73}$ F. Kamidjan, “Untung Wayang Kulit Masih Ada." 
instrument to be used by the dhalang; in Chapter Three I discuss how this quality of the puppet makes it possible for the puppeteer to hold the puppet in such a way that he can connect to it, that he can communicate to it his living physicality, that it becomes an extension of his body 74 ; in Chapter Five I describe how the dhalang "incarnates" his voice into the puppet, showing how an organic bond is established in another way. In this essay we have seen how in various ways the organic bond is deteriorating, it is "set aside," together with the centrality of the puppets and the puppeteer, and it disappears completely when the puppeteer speaks as himself, rather than as a character represented by the puppet. When this connection between the puppet and the puppeteer disappears, and when the puppets and the puppeteer themselves become no longer essential-is this still a wayang performance? I am not implying that there cannot be an excellent performance or show which is not wayang, or which only plays with wayang, evokes it, or refers to it. I am only suggesting that certain performances are so different from wayang that people who assert they are not wayang make a good point, and that questions about whether a certain performance is or is not wayang are fraught with ambiguity. What wayang is is ambiguous, and this ambiguity is an intrinsic characteristic of "wayang" performances. That is, such disagreements are not only theoretical; they reflect how the performance itself is in the world, its inner conflict. Thus, statements that claim that such "progress" is good because it is natural or inevitable, though not necessarily wrong, oversimplify the situation and fail to bring to the fore the tensions and conflicts that characterize the performance.

Part of this conflict is wayang's relation to its sponsors and audiences. Amien Nugroho writes:

In a traditional society, the organizer is a person of power in the region or a sponsor that holds a celebration, and the spectator is whoever is directly involved in the performance. In the modern world, the organizers are the impresarios [impresariat], and spectators are those who want to buy a ticket. Thus, in the modern world, a performance art will not exist without the existence of the attending spectators. The spectators will come if the performed art is interesting. For the basic need of modern spectators is to look for "fresh air" to release the exhaustion and tension of everyday life. ${ }^{75}$

This may be oversimplified, but the terms are interesting, especially the assertion that, in contrast to traditional society, "in the modern world, a performance art will not exist without the existence of the attending spectators." It would seem that the dilemma is thus between building a wayang performance as a structure that stands on its own on the one hand, and, on the other, presenting a show that merely follows the wishes and whims of the audience, the trends of the times, the demands of the market place, and so forth; that depends upon the support of the audience, rather than standing, like a building, on its own. Each dhalang in each performance faces the dilemma today. Should he move the puppets in ways that they were made to be moved, that they ask to be moved, or demolish them in order to please the audience? Should he present a performance that stands on its own, bring forth the structure and

\footnotetext{
${ }^{74}$ See also my "More than a Picture: The Instrumental Quality of the Shadow Puppet," in Studies in Southeast Asian Art: Essays in Honor of Stanley J. O'Connor, ed. Nora A. Taylor (Ithaca: Cornell Southeast Asia Program, 2000).

75 Amien Nugroho, "Pagelaran Wayang Kulit Perlu Pembaruan?" Kedaulatan Rakyat, September 29, 1991.
} 
146 Jan Mrázek

its wholeness, connect himself to the puppets and the work, or should he "take a break" and show off whatever the audience asks for? The distinction between the two is not so clear-cut perhaps-traditional performance too is made to be enjoyed by the audience-but in itself it is important and Javanese, and my exaggerations may at least help to point to it.

Criticizing innovation that goes too far, Manteb writes:

It is a great mistake if young dhalangs say as an excuse that they follow the audience. Because it is precisely the audience that can be controlled/managed [dikendalikan, from kendali, "reins"], and they would also have the same perception of the performance [as the dhalang], when they are presented with a performance that has its basis. ${ }^{76}$

The question is this. Should one "follow the audience," as the younger dhalangs do, or present a performance that "has its basis" (maton), "that is as it should be," that is, a performance built up with performance principles (waton) in mind? Such a performance, according to Manteb-and here he is on the side of older dhalangs-can control the audience, lead them in its direction, and make them see it in the way that the dhalang does.

It may be, as people say, that it is all because of the times; perhaps these are the times of comedy, of TV-like images, of attractions. Dhalangs and other observers say that the innovations take place because people go to performances mostly to relax after tiring work, they look for easy entertainment after the business of the day- $\mathrm{Ki}$ Suryasaputra used as an example the hassle at a market. Others say that people are used to the "easy" watching of TV or cheap films, and that watching a traditional wayang performance is too difficult: spectators are "spoiled" by easier performances.

Through film, television, as well as video, people of these times are already used to enjoying a story or a fairy tale that takes about two to three hours. And even that while sitting in a cushioned chair in a hall with $A C$. Being spoiled like this may make people consider watching a wayang performance to be a self-torture, because they have to jostle in the crowd and fight sleepiness due to the performance's length. Well, would it be possible for wayang spectators to have comfort [kemanjaan, "what spoils"] like the spectators in a movie theater?77

Even in traditional performances, the clown scene is described as a time when the spectators can rest (ngaso), "take a break," from the tension of the other parts of the performance. Whence this tension? It derives from the effort required for the work, from being involved in the performance, from grappling with the openness of the structure as a potential to be realized, from trying to make sense of the performance; these require work. The clown scene is not only a break, a gap in the structure; it also offers a break from the work. Thus, the expansion of the clown scenes, and the changing character of the performance in which attractions that require little work on the part of the spectator predominate, are motivated by people wanting to take a break from work, including the work involved in making sense of the complex structure

\footnotetext{
${ }^{76}$ Ki Manteb Soedharsono, quoted in Joko Dwi Hastanto, "Dari Sarasehan Wayang: Menggugat Kreativitas Dalang," Suara Merdeka, October 12, 1996.

77 "Pesona Wayang 6 Jam."
} 
of wayang performance. They prefer a potpourri of attractions in which the parts do not ask to be connected. During a clown scene, especially the expanded clown scenes common today, not only the dhalang and the puppets, but the spectators as well, take a break. The question is this: when does "taking a break" in the midst of the performance "go too far," so it becomes rather a continuous "taking a break." The expansion of the clown scenes, and the transformation of the whole performance into a clown scene, may be a sign that the Javanese wish to take a break from the complexities of wayang performance beyond the clown scenes, to be excused from the work that is the wayang performance.

In 1987, in a performance that was then considered "revolutionary" but that today would be commonplace, a dhalang used a rock band in addition to gamelan, a dancer in the middle of the performance, and other attractions. An Indonesian magazine reported, "In Solo, there is a 'revolution' fighting sleepiness."

"If needed, in the future, I will show disco-lights on the screen, billows of smoke like in the play of young kids on the television," he [the dhalang] said, laughing, showing that only one of his upper teeth remains. "My enemy at this time is sleepiness attacking the spectators. So, I must make the story alive, so that the spectators are interested/attracted and not sleepy," he said. ${ }^{78}$

The Javanese are tired. The performance must not tire them with too much work, and it has to keep them awake with various spektakuler attractions. Even breaking down the structure of the performance, or demolishing the puppets, makes a good attraction; it is an easy way to fight sleepiness. A certain degree of self-parody, of breaking the rules for the sake of theatrical effect, often as a joke, is an important technique even in traditional wayang; but again one must ask whether the structure is able to contain this, or whether it goes too far, so the whole structure collapses. If we have discussed in different contexts how breaking apart of the structure, showing the characters and the dhalang as crazy, making wayang a parody of itself, are all elements presented as the main attractions of the show, then Humardani, a charismatic figure in the earlier days of the arts academy in Solo, and a promoter of innovation, said: "Biar dalang membawa meriam atau bom sekalipun, asalkan penonton mau, silakan!" 79 ("Let the dhalang bring a cannon or even a bomb-as long as the spectators want that, go ahead!") This might be a good way to wake up wayang spectators, and the bomb might even be the final solution to the problems. And this might be a good, even spectacular, way to end the essay.

The problem is that at present the Javanese, tired though they may be, do not seem to be ready or able to get rid of the wayang performance, of its structure that fits the space of the Javanese house and the changing atmosphere of night, of the puppets as they are held by the puppeteer, even if they sometimes might unconsciously wish to; they, or many of them, are still to some extent "controlled," "led" by the performance because they are still open to it.

So, the focus of this essay could be misleading-this essay must be seen as a product of a particular, limited perspective. Even in the most "modern" performances

78 “Wayang Rock, Mas,” Tempo, January 31, 1987, p. 74.

${ }^{79}$ Quoted in Komar Abbas and Seno Subro, Ki Manteb "Dalang Setan," p. 99. 
148 Jan Mrázek

many of the basic elements that make a wayang performance remain to some extentand often to a great extent-present, and the building holds up, the work, the building up, goes on. And even in traditional performances there is much comedy and a certain degree of presenting the various elements as "separate attractions" (battle scenes, jokes, and so on). This essay articulates tendencies, often subtle developments, and the focus might have made these at times appear clearer and less complex than they are: "... anything we say, including my present remarks, is a combination of hopeless simplification and an attempt to draw from the tangled web of things and events something essential that may, at first sight, have remained hidden." 80

This essay focuses on the foreignness of innovations; to balance against this focus, another discussion ought to provide a historical account that would also show how many of the innovations can be understood as technical developments, as elements that further this construction of the performance and the structure-and indeed many developments are well integrated into the structure. But this was not the focus of this essay. My dissertation has shown the wholeness of the structure as it is today and examined various innovations that have been incorporated into it. For instance, I have discussed the use of a number of drums and drumming techniques associated with them, which is one of the innovations that is well integrated into the structure (in the past, only one drum was used in wayang). I have discussed it not as innovation, but as a technical element.

There is great variety. Some performances today are very much like a single clown scene, and many others stand firm like a building, they have an architectural unity, and they emanate a feeling of careful composition. Most dhalangs know how to hold the puppets well-and the standards for traditional skills like this are still very high-and even the most innovative dhalangs use traditional techniques for the most part, and merely add new techniques, while old dhalangs too joke and entertain the audiences, occasionally make fun of wayang or do crazy things. The conflicts inside notwithstanding, the building, the well-structured work, still is, it holds up; and because it has not quite collapsed, people still argue passionately about it, the performers feel the dilemma discussed here, and there are conflicts in the performance itself. Some Javanese never see wayang and are not concerned about it, but for many others it is still something that they have to face. People fear for it and are concerned about its development, or (rather rarely) dislike it, because it is still standing, because they have to face it as something that is there, because the performance, for the most part, goes on, and because it-and its sounds and images, its atmosphere, the kind of work, the way that everything is put together, the way that it presences forces from the "raw" human world, the way it represents humans-is still so much a part of many, though not all, Javanese houses, nights, human encounters and gatherings, and the selfunderstanding of Javanese as humans; because it still resonates with people's lives and the world; and, standing there as one of the buildings in the world, it not only metaphorically resonates, but is materially, physically there, as a self-sufficient presence, and as such it is an integral part of people's lives and their world, like their houses, or like the night air. Like a tree standing in the middle of a marketplace with traffic circulating around it, the performance is changing and growing. It often grows in strange ways to fit the changing place and the increasing "traffic" around it (some

${ }^{80}$ Havel, "Politics, Theater, and Clownery," p. 5. 
people say that now, standing there in the midst of the busy market, it is not what it used to be), but it also benefits from pruning, at the same time that it remains rooted in the human world like the tree is rooted in the earth. This rootedness-not an unresponsive manner of being "stuck" in the earth, but rootedness of a living tree that grows and owes its life and freshness to the fertile earth-might not have an immediate appeal, but it is something that television and the world "married" to television characteristically lack. With the TV constantly on, it is at times getting increasingly difficult to hear the "resonances" of the wayang performance and recognize its rootedness, recognize that it is not merely another image on TV (it is also difficult because wayang is often also that, and TV itself has its own ambiguities and dilemmas). At other times, and especially for people who are open to recognizing it, wayang is there very powerfully, with confidence. Generally, older people can hear the resonances better, and see wayang - not a wayang-relic but a constantly developing performance medium responsive to its world-as one of the things that constitute the world in which they are, like the houses and the trees (or, as one Javanese said, wayang is to some Javanese like rice: it is what they "live on"); or people (those who have to face wayang as a part of their world) grow to recognize this, as they grow to recognize themselves.

The beautiful tree may have been a little in the way of the traffic in the courtyard: I have heard that each heir in turn in his young years, on practical grounds, always maintained against his father's veto that it ought to be cut down; only one day, having succeeded to the property, to protect it from his own son. 81

This is then another side of wayang's being in the world.

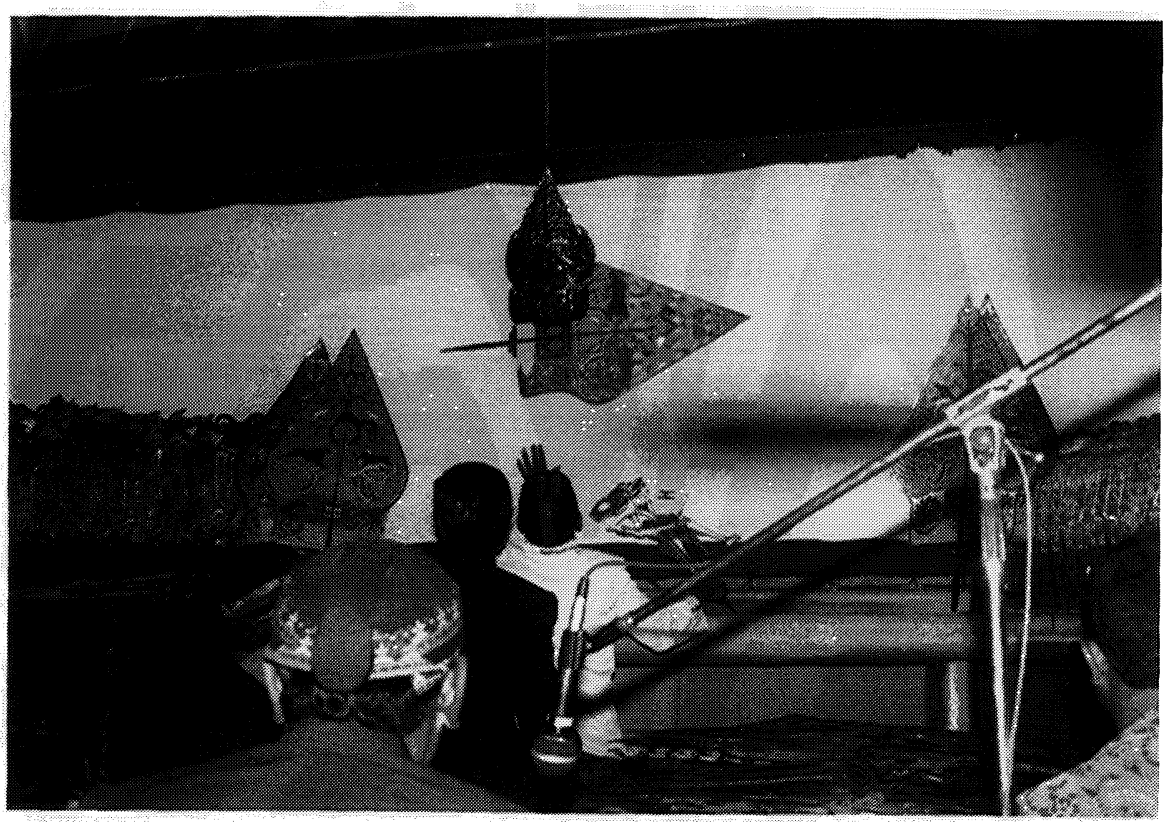

Figure 8. Little Bayu, a guest star at his father's (Anom Soeroto's) performance, somersaulting the "tree-oflife" puppet.

81 Thomas Mann, Doctor Faustus, trans. H. T. Lowe-Porter (New York: Alfred A. Knopf, 1948), p. 11. 


\title{
POSTSCRIPT. "THE PUPPETEER WON'T RUN OUT OF STORIES": WAYANG IN THE ERA OF REFORMASI AND KRISMON ${ }^{82}$
}

\author{
Kali ini Ki Manteb menyiapkan lakon [ . . . ] sesuai alam reformasi. [ . . ] \\ "Yang jelas dalang tidak akan kehabisan cerita," ujar Manteb sambil \\ tertawa. \\ (This time Ki Manteb prepared a play [ . . . ] conforming to the world \\ of reformasi. [ ... ] "One thing is clear: the puppeteer won't run out \\ of stories," says Manteb, laughing.) ${ }^{83}$
}

When I finished writing this essay in December 1997, I appended this (foot)note:

In the last part of the essay, I have tried to give a sense of the limits of the essay, of what it is not focusing on. Moreover, while my primary focus is on an in-depth examination of the wayang performance, I have at times felt an urge to superficially describe, to present a preliminary sketch, of some of the innovations and the characteristics of the "innovative" mainstream performances in the 1990 s, because there is practically no up-to-date account. ${ }^{84}$ While I generally do not believe in the virtues of being up-to-date, I do enjoy reading reports in old travel books that give a feeling for the time and place, and I hope that this essay may be of similar interest. Also, not only do the performances of course continue to develop, but as I have been writing this essay, interesting materials-reports on performances, articles on innovation in wayang, on Campursari, etc.-have continued, and continue now, to appear in Indonesian and Javanese newspapers and magazines. Due to this, too, this is very much a preliminary sketch, it only begins to rise questions about what is happening now.

One often hears that we will need a historical perspective to fully understand what is happening today. But now, as I look back at the essay, I realize that my sense that I was describing something as it was happening, the fact that I did not have a historical perspective (in the sense of writing about it as history), was not exclusively a shortcoming. Maurice Merleau-Ponty writes about historical representations of the Battle of Waterloo:

The historian who is not engaged in the battle and who sees it from all angles, who brings together a mass of evidence, and who knows what the result was, thinks he has grasped it in its essential truth. But $[. .$.$] he does not bring before$

\footnotetext{
82 This Postscript was written in January 2000, on the basis of my visit to Indonesia in 1999, as well as newspaper reports and discussions with friends. I am also indebted to Suratno for answering my questions via "solonet."

83 “Malam ini di Sasana Hinggil: Ki Manteb Gelar Lakon 'Pandhawa Timbul," Kedaulatan Rakyat, January 9, 1999.

84 An exception is Pausacker, Behind the Shadows, pp. 26-48, a recent account paying attention to performance practice, but it is very brief (it originated as program notes for a wayang performance in Melbourne). For a collection of studies that consider the modernization of wayang in different parts of Indonesia and wayang's place in the present world, unavailable when this essay was written, see Puppet Theater in Contemporary Indonesia: New Approaches to Performance Events, ed. Jan Mrázek (forthcoming).
} 
us the battle itself since the issue was, at the time, contingent, and is no longer so when the historian recounts it, since the deeper causes of defeat and the fortuitous incidents which brought them into play were, in that singular event called Waterloo, equally determining factors, and since the historian assigns to the said singular event its place in the general process of decline of the Empire. ${ }^{85}$

And in footnote: "It would therefore seem that history should be written in the present tense. [ . . . ]"86 A lack of historical perspective-not knowing the "results"-compels one to describe what is happening in its contingency, without reducing it into causes. Facts and ideas that may appear insignificant or fortuitous from a historical perspective, and that therefore may be lost in that perspective, may be no less significant today than that which a future historian identifies as the significant phenomena, that is, phenomena that fit into a historical representation as causes or effects. Without a historical perspective, one is compelled to represent "the battle itself" and the people who are "engaged in the battle," the result of which is not known; that is, one draws near to their own experience of their times. This is a positive aspect of my essay here: that it was written about something as it was happening. In the following postscript, I would like to offer a similar perspective on the years 19981999, apparently a turbulent period in Indonesian history, a time in which "something" is happening though we do not know quite what. People's experience of these years is characterized by contingency, uncertainty, perplexity.

Watching reformasi on CNN or reading about it in the press, one gets the sense that politics-desire for freedom and democracy, struggle against oppression and dictatorship-have been central to the transformations that began in 1997. I will therefore begin by focusing on politics. How have wayang and puppeteers fared in this apparent struggle? And has the situation been such a struggle-for freedom, for democracy-for puppeteers and their audiences? Slenk:

Let me start by quoting Suratno, who writes about the popular dhalang Warsena

When reformasi rolled in after the end of Soeharto's leadership, Warsena Slenk was first confused about the attitude he should take and on whose side he should be, because on his way to build a career he had been very much helped by officials of the Soeharto's New Order era. Finally he decided to follow the current of the society, that is, to be on the side of reformasi. In his performances, he has followed the trend [ikut-ikutan] of criticizing the wrongdoings of the New Order government. He has taken this up in order to continue to be sympathetic to the people. [ ... ]

During the [1999] pre-election campaign, Warsena Slenk was waiting and trying to figure out which party would be supported by the people. At one point, Megawati's PDI Perjuangan [Partai Demokrasi Indonesia-Perjuangan, Democratic Party of Indonesia-Struggle, previously PDI] sponsored his performance, and after that he was repeatedly invited to perform as a part of the PDI Perjuangan campaign. In these performances, he was always praising the

\footnotetext{
${ }^{85}$ Maurice Merleau-Ponty, Phenomenology of Perception, trans. C. Smith (London and New York: Routledge, 1962), pp. 362-3.

${ }^{86}$ Ibid., p. 363.
} 
152 Jan Mrázek

superior qualities of Megawati compared to other parties, and he constantly spoke of the importance of unifying under the leadership of Megawati. In this way, Warsena Slenk was able to get the support of the PDI Perjuangan community, and he was frequently invited to perform by that community. The frequency of performances of other dhalangs-including the most famous ones, Anom Suroto and Manteb Sudarsono-was very low. Warsena, on the other hand, performed fifteen times in July 1999 and twenty-three times in August 1999.

As another opportunity, he also continued his active relations with other parties such as PKB [Partai Kebangkitan Bangsa, National Resurgence Party], LSM [Lembaga Swadaya Masyarakat], Golkar, and ABRI [Angkatan Bersenjata Republik Indonesia, Indonesian Armed Forces]. In the performances sponsored by those groups, he made a statement that he is an "independent" dhalang, meaning that he is for anyone who will sponsor him.

In conclusion: the monetary crisis and the reformasi have not decreased the frequency of Warsena's performances, because he is skillful in taking advantage of a situation and in finding a way to continue to be popular in society. ${ }^{87}$

We have seen that when Suharto was in power, all the top puppeteers thrived on their association with the ruling Golkar party and the government. Following the fall of Soeharto, these dhalangs began, like Warsena Slenk, to distance themselves from Golkar and the New Order government, and, like most people, began to criticize it and voiced their support for reformasi, demokrasi, and so forth. Suratno uses the word "ikutikutan" - which a dictionary translates as "always a follower, going along with whatever happens to be the prevailing view, fashion, etc." 88

Let us look at the politics of some of the top dhalangs in the era of reformasi. A newspaper article entitled "Offered Rp. 250 million for 'Reformasi' of Ki Manteb" reports that Manteb, who formerly often accepted sponsorship from Golkar and the New Order government, is bargaining with a cassette producer from Jakarta about the price for the song "Reformasi" that he has composed (Manteb has been offered Rp. $250,000,000$, but he is asking $500,000,000$ ) as well as "five other songs relevant to the situation in the homeland," such as the song "KKN" (Korupsi-Kolusi-Nepotismeanother catchword associated with reformasi). ${ }^{9}$ When the price is agreed on, Manteb will arrange the songs for "pure gamelan, campursari [mixture of gamelan and nongamelan music], or campursari dangdut [mixture of campursari and dangdut]." In the meantime, he plays "Reformasi" and the other songs during the clown scenes. A reformasi song becomes one of the many attractions of the clown scenes. Like Slenk, Manteb is able to make money on reformasi.

At the same time, Manteb says he wants to "conduct reformasi of [his] self" (melakukan reformasi diri)_"At least, I won't marry any more wives. Hehehe . . "90

\footnotetext{
87 Suratno, "Ki SLENK (Saya Lebih Enak Nonton Kamu): The Tactics Of a Best-Selling Puppeteer," trans. Jan Mrázek, in Puppet Theater in Contemporary Indonesia: New Approaches to Performance Events, ed. Jan Mrázek (forthcoming).

${ }^{88}$ John M. Echols and Hassan Shadily, An Indonesian-English Dictionary, rev. and ed. John U. Wolff and James T. Collins (Ithaca: Cornell University Press, 1989), p. 219.

89 “'Reformasi' Ki Manteb Ditawar Rp 250 Juta," Suara Merdeka, November 27, 1998.

90 "Nama dan Peristiwa," Kompas, August 28, 1998.
} 
When Soeharto resigned, the president used the wayangoid expression lengser keprabon ["retire from kingship"] to refer to his resignation, and the phrase came to be popularly used to refer to the resignation of corrupt officials. A few months later, Manteb says that "I have long wanted to lengser keprabon from wayang-just-for-fun [wayang hurahura]." ${ }^{91}$ It seems thus that he connects wayang-just-for-fun with the New Order, and he sees puppeteers who perform it, like himself, as corrupt (he speaks about the "sins of dhalang-art from which dhalangs like Ki Enthus Susmono and Ki Djoko Hadiwidjojo [Crazy Djoko] were born"). Interestingly, as we will see, this kind of wayang-just-forfun continues to be popular and works for reformasi as it did for the New Order, and Manteb's 1998 statement reveals some confusion about what reformasi means, or would mean, for other people and for wayang. Certainly words like reformasi and lengser keprabon, and other words associated with reformasi, are very important to what has been happening in Indonesia, but this does not mean that people have a clear idea of what the words mean or that they agree on the meanings of the words. Nonetheless, the words are spoken and sung, and in that way they participate also in wayang performances.

In June 1998, the Reformasi Student Council Surakarta was planning to sponsor wayang performances. The famous Solonese dhalangs-Manteb, Anom Suroto, Warsena Slenk-enthusiastically agreed to perform "on the theme of reformasi" (bertemakan reformasi).92 It is interesting that precisely those dhalangs who had been most closely associated with Golkar were now the most active in "performing reformasi" (pentas reformasi). Incidentally, Anom Suroto, perhaps most closely associated with Golkar in the past, has also composed gendhing (a gamelan composition) "Reformasi," which is performed during the clown scenes. 93

I have discussed a 1996 performance of Enthus Susmono, that featured performers dressed in yellow (the color of Golkar), a "tree of life" puppet (kayon) displaying the symbol of Golkar party (the banyan tree), and a story that quite explicitly supported Golkar and Soeharto before the then-upcoming elections. Apparently, Enthus's past association with Golkar and the government is not seen as a problem or stain on his reputation. In this new era of reformasi, he has been invited, for instance, to celebrate a typical reformasi-event, the resignation (the newspaper report uses the word lengser, alluding to Soeharto's lengser keprabon) of the corrupt mayor of Enthus's native town, Tegal, in September 1998.94 The performance was attended by some seventy thousand spectators. 95

Not only individuals, but also organizations, are reformasi-ing themselves. For instance, Ganasidi (Institute Cultivating the Art of Dalangry in All Indonesia), formerly closely associated with Golkar and more or less an instrument of the government for controlling and indoctrinating dhalangs, "is determined to reformasi itself [mereformasi diri]." According to the Chairman, Sudjadi, formerly a powerful person in Central

\footnotetext{
91“ Ki Manteb Tokoh Budaya 1997 Versi Suara Merdeka (1): 'Saya Ingin Lengser dari Wayang HuraHura,"' Suara Merdeka, August 29, 1998.

92 "Para Dalang Siap Pentas Reformasi," Suara Merdeka, June 23, 1998.

93 "Bikin Gending," Suara Merdeka, February 13, 1999.

94 "Seputar Nusantara," Media Indonesia, September 22, 1998.

95 "Ribuan Petugas Amankan Pentas Dalang Mbeling," Suara Merdeka, May 1, 1999.
} 
154 Jan Mrázek

Javanese government politics and co-creator of some of the grandest Golkar wayangs, said that this is "in accordance with the current of reformasi that is rolling in." According to the dhalang Enthus Susmono, Ganasidi should now be "not only the mouthpiece of government, but also the mouthpiece of people." 96

When joining the current of reformasi, it had become customary to pronounce oneself "independent" or "neutral," because distancing oneself from the New Order means also distancing oneself from one-party politics. However, the state of being "independent" or "neutral" has to be also understood in this context of general confusion and uncertainty. Many people have vivid memories of the mid-sixties when so many dhalangs worked in close association with the Communist Party and were later killed, imprisoned, or forbidden to perform. Moreover, as Suratno writes about Slenk, for Slenk to be "independent" means he will support any party that will pay a dhalang to be for that party. Slenk himself says: "Now I am free and owned by all parties [Saya sekarang bebas dan milik semua partai]."97 Anom Soeroto, Slenk's older brother and the most expensive Solonese dhalang, also says he is independen and netral, and he explains it as "standing above all parties [berdiri diatas semua pihak]."98 At the same time, most dhalangs try to have good relations with the dominant PDI-P and, like Slenk and Manteb, may even call themselves "PDI dhalangs."

An interesting phenomenon in this regard was the "Gulang Data" group:

Before the 1999 election, [Slenk], together with Anom Soeroto, participated in a series of performances at different places with the group Gulang Data [Guyub Dhalang Mudha se-eks Karesidhenan Surakarta, "Union of Dhalangs of the exSurakarta-Residency"], which he organized. This group consisted of young, "well-selling" dhalangs of the ex-Surakarta-Residency. According to Warsena Slenk, the intention of this group was to entertain the people in the pre-election times and to cool down the atmosphere. On the other hand, one intention of Warsena Slenk was to make himself popular and refresh the market for wayang performances, which has been hit hard by the monetary crisis in Indonesia [beginning in 1997-98]. In the series of performances, all the musicians were dhalangs (Manteb Sudarsono played rebab, Anom Suroto was singing). A performance was organized in each district in the Surakarta region with the financial help of local governments. ${ }^{99}$

In their performances, they played the song "Pemilihan Umum" ("General Election"), "sweet, full of spirit, and spiced by shouts of 'merdeka' [freedom]," to give "a positive impression to the society that puppeteer-artists don't like the status quo either," according to Slenk, the coordinator of the group. ${ }^{100}$ The group declared itself to be "independen artists and not the instrument of a political party or a particular political organization."101 In the newspaper article "Wayang refuses to smell of political

96 "Ganasidi bertekad mereformasi diri," Solo Pos, February 21, 1999.

97 "Independensi 'Gulang Data' Banyak Dipertanyakan," Suara Merdeka, May 26, 1999.

98 "Rp 600 Juta Ditolak," Suara Merdeka, May 14, 1999.

99 Suratno, "Ki SLENK."

100 "Lagu 'Pemilu' Berkumandang di Pentas Guyub Dalang Muda," Suara Merdeka, March 11, 1999.

101 “Independensi 'Gulang Data' Banyak Dipertanyakan." 
parties," Slenk is quoted saying: "We, the young dhalangs, want to be really clean. We want to be netral and independen. We don't want to repeat the mistakes of the past."102 And yet, according to the newspaper article "The Independence of 'Gulang Data' Much Questioned,"

... their seven appearances could be hardly called entertainment intended to make people forget the monetary crisis and political tension. There was a rumor that the performances were not paid for collaboratively by the puppeteers, but were paid by the local government acting as the arm of a certain political party. 103

So, how do the top dhalangs and their performances relate to politics? They ikutikutan, they go along, today as they did during the New Order. Considering my description of wayang and politics in the New Order, this should not come as a surprise. Writing in 1997, I emphasized that "politics are certainly important, especially because dhalangs are dependent on sponsorship, and government functionaries have been for a long time-one could say traditionally-major patrons"; and "the dhalang's involvement in politics is a part of his endeavor to provide for himself and his musicians," but "it would be misleading to try to explain contemporary wayang's evolution by focusing exclusively on how it has been influenced by national politics." In a recent article, Ward Keeler has stressed the position of dhalang as a client who has to please his sponsor, and from Suratno's essay, a section of which I have quoted above, it is clear that Slenk's involvement in politics is a part of his "strategies of a best-selling dhalang."104 Of course, wayang cannot be fully understood as a business either, though business may be closer to the concerns of most puppeteers than politics. In a forthcoming collection of essays on wayang, a number of writers describe from various perspectives, among other things, the puppeteers' involvement in politics and business in various parts of Indonesia, ${ }^{105}$ but for the purposes of this postscript it is enough to see that there is a clear continuity in the way that dhalangs have related to politics in New Order and in the era of reformasi, and that then as now their position as clients has been a decisive factor. This helps us to understand that the attitude of the puppeteers is not simply opportunistic and in conflict with the proper situation of artists, who ideally should be free and should express ideas in which they believe; as Keeler has shown, such a characterization grows from a mistaken application of "romantic notions of the artist " to the dhalangs. ${ }^{106}$ Instead, we can see that the puppeteers look for sponsors whom they need if they want to perform. This does not mean that the puppeteers say only what they are paid to say, because they are to some extent allowed to criticize or ridicule the sponsor (often that is part of the entertainment), and especially because most of the performance is not about governmental or party politics. As I have tried to show

102 "Wayang Tolak Berbau Parpol," Suara Merdeka, March 22, 1999.

103 "Independensi 'Gulang Data' Banyak Dipertanyakan."

104 See Ward Keeler, "Wayang in the Political Margin," in Puppet Theater in Contemporary Indonesia: New Approaches to Performance Events, ed. Jan Mrázek (forthcoming); and Suratno, "Ki SLENK."

105 In addition to the essays by Keeler and Suratno, see especially the contributions by Matthew Cohen, Andrew Weintraub, Richard Curtis, Judith Ecklund, and Tony Day, in Mrázek, ed., Puppet Theater in Contemporary Indonesia (forthcoming).

106 See Keeler, "Wayang in the Political Margin." 
156 Jan Mrázek

earlier in this essay, politics are only one of the many things that have to be considered if one wants to understand the multifarious event that is performance.

Thus, while wayang performances are sponsored by various political parties and, as in the past, references to politics penetrate the performances-often as another kind of entertainment, as we see when songs like "Reformasi" and "Pemilihan Umum" are played-the way that wayang relates to politics itself has not entirely changed. This is also apparent from the attitude of the political parties. Many of the PDI-P dhalangs are ex-Golkar dhalangs (such as Slenk and Manteb), and the fact that this is not seen as a problem suggests that the puppeteers are generally perceived as clients and as entertainment industry celebrities who help to bring people to events sponsored by a political party. Moreover, the fact that PDI-P, like Golkar before, sponsors wayang performances and tries to make wayang serve its ends, should be noted as evidence of a significant continuity.

An example. When PDI-P won the election in 1999, it sponsored a wayang with ten female singers, including a special attraction, a singer from America (one may be reminded of the londo in the performances of Crazy Djoko discussed in the first part of this essay). If in the past wayang was called on to support Soeharto's rule through pertinent references and allusions, now PDI-P-sponsored wayang supports Megawati by showing a story featuring a woman-leader, which was especially relevant to the current reformasi politics because Megawati's candidacy was attacked by individuals who argued that predominantly Moslem Indonesia should not be led by a woman. The newspaper article "PDI-P wins, Sponsors wayang, Singer from America" reports:

... the central character in the wayang play tonight will be Dewi Drupadi. The story is about the ability of a woman who is no worse than a man in leading and managing a country. "We wish to show to the people that a woman can also lead a country," said [the director of the organizers].107

The dhalang, moreover, was a woman-another way to show that a woman can take charge.

In the above discussion, I have focused on the top dhalangs and on what appear to be the major trends in wayang's relation to politics. However, many "smaller" events and "smaller" dhalangs do not necessarily conform to the above description. Many local, "smaller" dhalangs were not strongly associated with Golkar in the New Order period, but neither did they make it a point to criticize Golkar. The recent political changes tend to be of much less concern to village dhalangs than they are to the top dhalangs.

Ki Sayoko and Ki Sri Joko Raharjo were rather exceptional in the way they consciously distanced themselves from Golkar in the past. Ki Sayoko has been close to the PDI party in the New Order period since 1992, which meant that he was not liked and supported by those in power, and his opportunities to perform were limited. After the fall of Soeharto, he became quite popular and since then has frequently performed for the now-powerful PDI-P. 108

107 "PDI-P Menang, Gelar Wayang, Sinden dari Amerika", Jawa Pos, July 24, 1999.

108 Suratno, personal communication, December 1999; and "Ki Sayoko: Dalang yang 'Akrab' dengan Aparat," Suara Merdeka, June 19, 1999. 
In a similar way, Sri Joko Raharjo kept his distance from the government and Golkar during the New Order, and though generally acknowledged to be an excellent dhalang, during the New Order he performed only a few times a month at small-scale village events for very low wages. During this time, he derived most of his income from raising dogs, until a puppy destroyed some of his puppets, at which point he began to raise pigs. He also taught music and puppetry to foreigners. After the fall of Soeharto, the PDI-P party sponsored him a number of times. I attended one such performance in February 1999. Crowning the middle of the screen was a picture of Soekarno, the father of the PDI-P's leader Megawati, and on each side of the screen was a painting of Megawati, looking toward the center, toward her father. (Figure 9) In the painting on the left, moreover, a smaller image of Soekarno floated like an guardian angel above Megawati. Toward the right, flanked by red-and-white Indonesian and red PDI-P flags - red being the color of PDI(-P) - there, decorated with red fabric, was the stage on which political speeches would take place before the performance; the backdrop of the stage showed a giant painted image of Megawati's face on red background. (Figure 10) In addition to the political speeches preceding the wayang performance, there were also speeches delivered during the performance, for during the first clown scene the puppeteer included what was basically another long political speech, praising Megawati and PDI, and asking people to unite behind her. The story itself, in which the good Pandhawa brothers came out of hiding after a thirteen-year exile in order to return to and rule the kingdom of Ngastina and replace the "bad" Kurawas, could be read as a political allegory (given Megawati's status as Soekarno's daughter, there was a sense that Megawati was "returning" to power). Not many people stayed long enough to pick up on the allegory, however, since most of the audience left after the second clown scene. As old dhalangs lament, nobody pays attention to stories today.

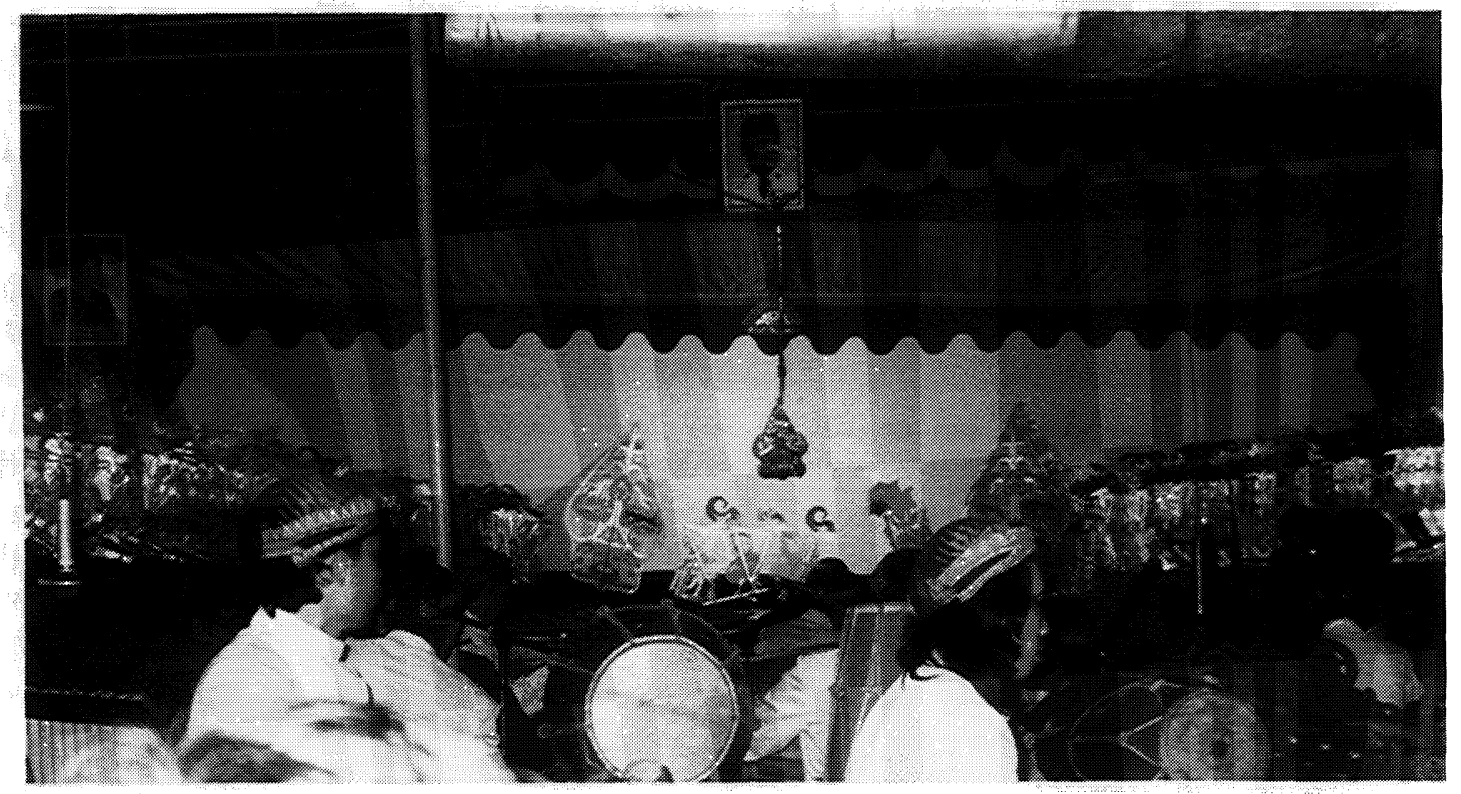

Figure 9. A pre-election performance sponsored by the PDI-P party in February 1999. The screen is decorated by portraits of Soekarno and his daughter Megawati, and the stage is decked in red, the color of the political party PDI-P. Dhalang: Sri Joko Raharjo. 


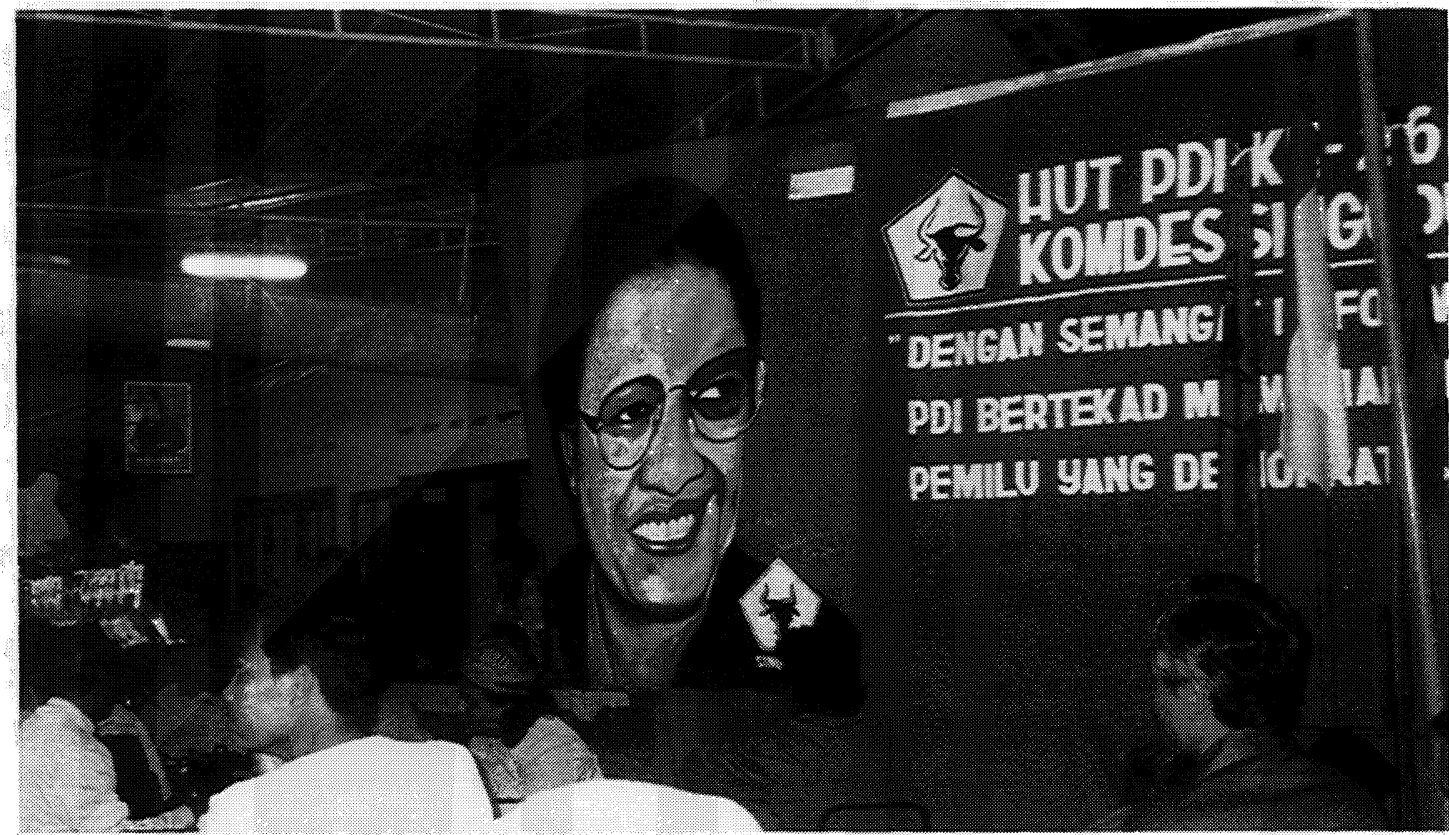

Figure 10. At the same performance, to the side, a big painting of Megawati's face dominates the scene, and Indonesian and PDI-P flags are visible.

PDI-P has sponsored several performances by Sri Joko, but partly because of the style of his performances-relatively serious and "heavy," with less focus on comedy and pop-music than most other dhalangs-Sri Joko does not have more performance opportunities or larger audiences than he had in the New Order period.

The PDI-P performance of Sri Joko that I have briefly described could not have taken place during the New Order. And yet, it is interesting to ponder how the performance was strangely like New Order performances in the way it related to politics. Instead of the yellow which dominated Golkar performances, the PDI-P performance was all decked in red. While the clown servants used to praise Golkar and Soeharto, in this performance they were praising PDI-P and Megawati. Even in the case of this performance one could argue that the way that wayang is political has not changed that much; only the party for which it speaks has. PDI-P wayang imitates Golkar wayang in using the color symbolism (yellow/red), in talking through the clown servants, and so forth. This is not to say that there are no differences. But the continuity in the way that wayang speaks politics-even in this performance where the dhalang was known to have criticized Golkar for a long time, long before such criticism became popular and profitable-is significant. And while wayang may be occasionally felt to be associated with, or, in its present form, even be the product of, the New Order and its politics, it nonetheless continues to be popular since the collapse of the New Order, and the newly powerful parties exploit wayang in the same ways Soeharto's regime did in the past.

On September 29, 1998, a group of villagers gathered to protest corrupt practices of local officials. In effect they staged a small day-time wayang performance in front of the appropriate office building, with the story "containing many allusions to the functionaries." The local police made a quick end to the performance, claiming that 
"the story offends other citizens." 109 This was a unique event, an atypical use of wayang, but it gives a sense of a certain degree of unpredictability in the way that wayang may become involved with politics, and the way that everybody tries to use it to their own ends.

Another example of the way that wayang is caught up in the various trends or "currents" (arus, another word popular in the era of reformasi), often opposing currents, comes to us from a report on two wayang performances of Anom Soeroto, each presented at a different university. During both performances, there was a student demo, but in one case the students protested against a wayang performance, because the money spent on the performance was allegedly taken from tuition payments ("But after it had been explained [that it was not the case], the students understood"). In another performance there was a student demo favoring wayang. Specifically, the students requested that the university sponsor wayang more often. Anom comments: "So it was the other way around. [ . . . ] They were very fond of wayang, and because the university had not sponsored wayang for several years, they protested." 110 Wayang is involved in this situation, but no single party has a monopoly on wayang and wayang is not associated with any single cause, not used in any single way; instead, it is "caught up" in different situations and currents, involved now in one way and then in another. This is part, or another side, of the confusion, uncertainty, and of ikutikutan, of following the various trends. (Incidentally, like reformasi, demonstrasi [usually pronounced demon-trasi] has become a kind of trend-a new way to deal with things.)

Though I am focusing here on performances and performers, I should at least briefly mention that reformasi itself is also a subject that generates many theoretical discussions and much rhetoric. A sense that some kind of change ought to take place pervades these discussions. Many people speak about how dhalangs should change their ways, reorganize, reeducate themselves, or rethink their function in society (such as being netral and independen), but there is little consensus and even less sense of how ideas might be applied to practice and how they might affect the actual lives and work of the puppeteers. Many issues are familiar from discussions from the past, and even many apparently new ideas were first raised long before reformasi. There is a degree of new excitement about speaking out and about changing things, but, as in wayang performance itself, this criticism of the status quo and a tendency to criticize everything is also a matter of fashion, of $i k u t-i k u t a n$.

Apart from these discussions, which address the state of wayang and which have continued from the New Order period into the reformasi period (and have been, to a great extent, generated by the same people then and now), there are other interesting theories about the state of wayang and the world. For instance, we have heard that "the wayang performance is indeed a picturing of the world. Therefore if wayang today is said to be broken, perhaps the being/condition of the present world is like that too." This view has new powerful resonances today, and many people speak about the present situation as a gara-gara, the "times of turmoil," and as a mega-clown-scene. For instance, on the last day of 1998 the paranormal Permadi predicted that the year

109 "'Pergelaran Wayang' Unjuk Rasa Dibubarkan," Surabaya Post, September 30, 1998; "Unjuk Rasa di Dewan Bawa Niyaga dan Pesinden," Jawa Pos, September 30, 1998.

110 "Wayangan didemo," Suara Merdeka, September 6, 1999. 
160 Jan Mrázek

1999 "will bring about gara-gara, as well as a great, wise leader."111 In April 1999 in Solo, two sacred wayang puppets from the Mangkunegaran palace were carried in a procession in order to protect the city from further disasters. Sudarko, an influential personality in various dhalang organizations, said that Indonesia is at the stage of gara-gara. "Sudarko said that the recent situation is like gara-gara in wayang performance. That is, it is a scene of only jokes and comedy, not unlike the appearance of political clowns [badut-badut politik] who like to talk much, but it is difficult to hold onto anything certain in what they say." He further predicted that, as in wayang, a knight will appear whose identity is now concealed. "The next scene is perang kembang [the battle scene that follows gara-gara, in which a good knight fights the ogre Cakil]," and just like in wayang, there will be conflicts, fighting, and victims "which in performance is the Ogre Cakil."112

I have discussed the view that wayang is crazy because these are "crazy times" (jaman edan). It is interesting to note that some people reverse the causality in this statement and argue that the situation of the world has been brought about by "broken" wayang performances. The mystic-artist-theaterman-professor-doctor Wisnu Wardhana, for instance, told me in February 1999 that the present turmoil in the world had been caused by crazy wayang performances. This view is reminiscent of the quite widespread belief that the 1965 crisis was caused by the wayang performances of the Communist Party (PKI), which, as I have noted, in many ways resembled the late-New Order performances (Wisnu in fact said: "just like in the PKI times"). Such interpretations suggest that the era of reformasi is perceived as an era of turmoil, of chaos, rather than an era characterized by progressive movement in a particular direction, and, as things get crazier and crazier, the reformasi era is perceived as the continuation and the climax of the New Order era. Permadi says that Soeharto has "intentionally created crazy times [zaman edan] in Indonesia." 113 These are not theories to endorse or argue against; rather they give us a feeling for how different people perceive the present.

If people are not quite sure what reformasi means and what are its specific goals, everybody feels the effects of the monetary crisis, some more severely than others. Indeed, many people make little distinction between reformasi and krismon (krisis moneter)-both terms are associated with economic crisis. The vacillations of the economy have also had a severe impact on wayang and puppeteers. While all dhalangs feel it, professionally the economic crisis has affected the most expensive dhalangs, such as Manteb and Anom, the most. Less expensive dhalangs suffer professionally somewhat less because a sponsor who in the past would hire one of the top dhalangs may now make do with a less expensive dhalang.

Lack of funds is the most obvious reason why fewer wayangs with the expensive top dhalangs are sponsored, and it is an important reason, but not the only one. I was told that many people think twice before sponsoring a wayang with a very expensive dhalang because sponsoring a wayang was and is a sign of status and wealth. Now, in

111 “Permadi: Kita Memasuki ‘Gara-Gara,'” Suara Merdeka, December 31, 1998.

112 “'Kiai Sebet' Dikirab: Isyarat Bakal Pecah Perang," Suara Merdeka, April 23, 1999.

113 “Dari Seminar 'Munculnya Satria Piningit': Soeharto 'Dijatah' Ciptakan Zaman Edan," Suara Merdeka, November 27, 1998. 
the era of reformasi, status and wealth, at the same time that they very much continue to be respected, are occasionally connected to corrupt practices, so the sponsor may fear that he will be accused of corruption. Government sponsors have felt the same pressure, and fewer large-scale performances are now sponsored by the government, in part because functionaries fear they may be accused of corrupt practices and of using up people's money. This does not mean that there are no large-scale events today, or that the most expensive dhalangs never perform, but people are more careful when they consider sponsoring a very expensive performance. These feelings are part of the general uncertainty experienced by people in the era of reformasi, part of the sense that actions have unpredictable results.

In fact, while some fear that sponsoring an expensive wayang could create a bad image, one encounters the opposite sentiments as well. We have seen that in one case university students protested because the university had not sponsored a wayang for some time, and in a paper one finds this letter from the readers:

We, the little people [rakyat kecil] of Java, like wayang kulit. When [you] Pak Imam were the Territorial Military Commander, once in two months you were sure to sponsor a wayang performance which is the entertainment for little people. Since Pak Imam has moved, there has been very rarely wayang kulit. Now Pak Imam is a Governor. Therefore, we very much ask that the [sponsoring of] the events/programs like in the past is taken up again. ${ }^{114}$

When there are fewer opportunities to perform, the top dhalangs look for other activities to engage them. It is interesting to see what kind of new "jobs" they find, because it tells us something about the dhalangs.

The article "Few Wayang Engagements: Dalang Djoko 'Sells' Wife," begins:

Effects of the economical crisis have also hit famous dhalangs, including Ki Djoko Hadiwidjojo, alias Crazy Djoko, from Pudakpayung. He says that there are many people sponsoring wayang kulit, but because their funds are smaller, it is the dhalangs from the cheap class [berkelas murah] who continue to sell, or those who lower their fees. ${ }^{115}$

Since now he has plenty of free time, Djoko, apart from going hunting in the forest, composes Javanese songs in the campursari and campursari-dangdut instrumentations and styles, and he produces them on audio cassettes and on VCDs (video compact disks). The cassettes bear such titles as "Tresnamu Luntur" ("Your Love Has Faded"), "Nonton Wayang" ("Watching Wayang"), and "Ngimpi" ("To Dream"). They feature Nurhana, the young star female singer whom Djoko recently married, and who has often performed with him on stage. The "MC [master of ceremonies] who doubles as comedian" is Bagyo Gareng, the comedian from wayang orang who frequently performs at wayang kulit performances in the make-up and costume of Gareng (see Figure 2; also see Indonesia 68, Figure 5 on p. 82, and discussion on p. 81). The tapes have "taken off and spread throughout Central Java. [ . . ] 'Selling songs and selling my wife, that's my business [bisnis] now,' says Crazy Djoko."116

114 "Wayangnya Mohon Diteruskan," Jawa Pos, August 16, 1998.

115 "Tanggapan Wayang Sepi: Dalang Djoko 'Jual' Istri," Suara Merdeka, February 24, 1999.

116 "Tanggapan Wayang Sepi." 
How does this activity of Crazy Djoko relate to his profession as a dhalang? Considering the trends and the function of the dhalang in the performances I have described in this essay, one can see a clear continuity. During the clown scenes in his performances, Djoko used (and uses) much Campursari and dangdut music, often sung by Nurhana. His own role as a dhalang has been that of a presenter or coordinator of songs and comedy. When he now says that he is the "manajer" of Nurhana, and he "directs" (menyutradarai) the music and action on audio tapes and VCDs, he makes it clear that this managerial role is in many ways similar to his role as a dhalangpresenter. The cassettes, furthermore, use Djoko's image as a dhalang. On the cover of the cassette Ngimpi which I bought, Djoko is advertised as "Ki Djoko Edan"-Ki identifies him as a dhalang, and Edan ("Crazy") refers to the way he performs wayang. The picture shows him standing next to Nurhana in the traditional Javanese dress that he wears when he performs wayang (see Figure 11). While some people have criticized Djoko for dancing and complained that his wayangs are like tayuban (dance parties) because Nurhana and other female singers and other performers, and occasionally even Djoko himself, stand up and dance, often with people from the audience, the cassette is subtitled Tayub Campur Sari, and Djoko and Nurhana are shown with their hands in dance gestures on the cover.

I have discussed how dhalangs have become celebrities comparable to soap opera actors and pop music singers, and Djoko's status as a celebrity makes his presence in the cassette and VCD industry feel like it is nothing strange. Wayang was and is for him, among other things, "bisnis," like producing cassettes and VCDs. ("We hope we can explode on the market," he says.) Further, I have discussed wayang's interaction with other modern media, including cassettes. For instance, Manthous is famous primarily for his cassettes of Campursari, but he is also a popular guest star at wayang

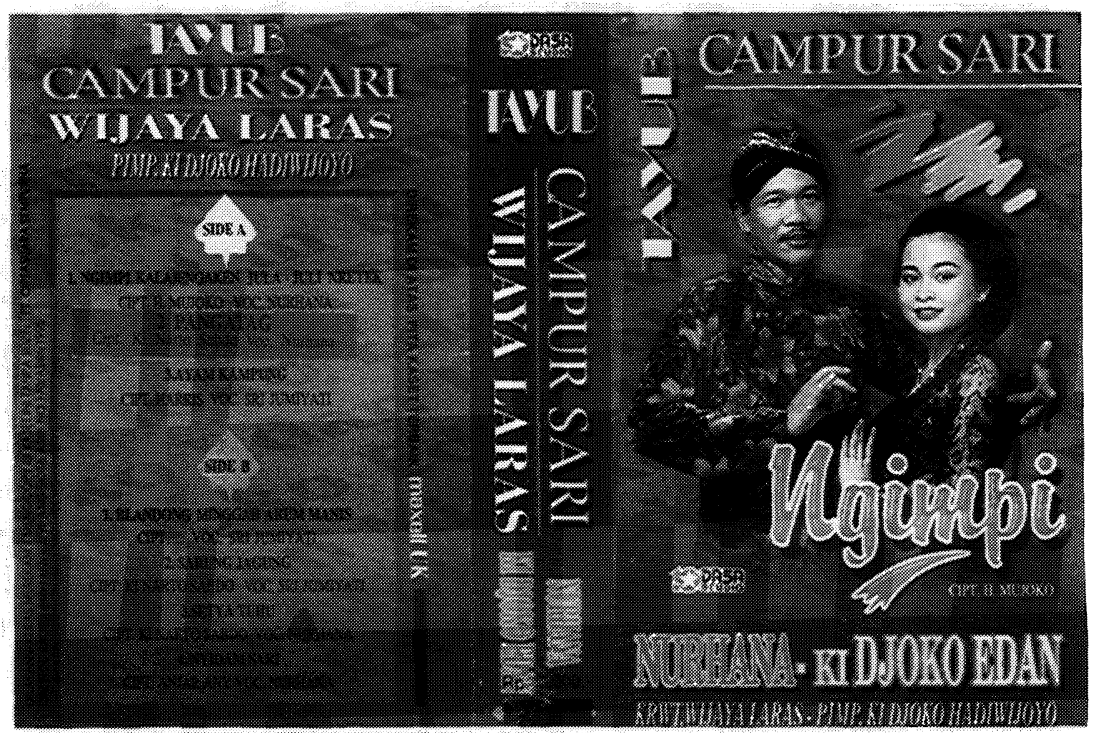

Figure 11. A Campursari cassette showing the dhalang Crazy Djoko (Ki Djoko Edan) and his wife Nurhana with their hands in dance postures. 
performances, and the music from his cassettes, and Campursari music in general, often dominates the clown scenes. Thus, wayang's closeness to other media, in this case cassettes, makes Djoko's present activities seem quite natural for a dhalang. $\mathrm{He}-$ or Manteb who also composes songs with the cassette industry in mind, as I have mentioned, or Sujiwo Tejo, a young dhalang who has recently become famous as a singer and who has produced cassettes and video clips of his pop-music songs ${ }^{117}$ had to travel no great distance in order to move from being a dhalang to being the producer of Campursari cassettes and VCDs (while at the same time he continues to perform wayang). This tells us something about wayang and dhalangs like Djoko. Looking farther back into history, one thinks of Nartosabdho-both a famous dhalang (then also called "crazy") and a popular song composer-as Djoko's predecessor because of his involvement with cassettes and song writing (many songs by Nartosabdho are rearranged for Campursari on Djoko's tapes). And as I am reading the final proofs of this essay, Richard Curtis, who was in Tegal in March 2000, reports on a current project of the dhalang Enthus Susmono: "When I was there he was filming his first VCD for his 'hit' 'Topeng Monyet' [Monkey Mask] which was on a campursari cassette he made. He commandeered me to act as Charles Darwin in one short scene."

Incidentally, Campursari continues to be very popular generally and to be an important element of most wayang performances, and there are many active Campursari groups. We have noted that Manteb and Anom have composed and perform songs entitled "Reformasi" in their performances. Campursari shares this interest in the reformasi. On one Campursari cassette, for instance, there is the song "Jaman Reformasi" ("Era of Reformasi"). On the cover of the cassette, which is itself entitled Jaman Reformasi, there are pictures of two pretty female singers, a smiling drummer, and a young man peacefully posing with a raised fist and red-and-white headband showing the word REFORMASI (see Figure 12). The red-and-white Indonesian flag forms the background. Apart from this one song, other songs on the cassette are pre-reformasi and express no political sentiments, and the emphasis on reformasi on the cassette cover is clearly motivated by commercial interests. Reformasi is new and trendy, and apparently the producers hoped the title would make the cassette "explode on the market." The lyrics of the song "Jaman Reformasi" express uncertainty and describe the way people are "overcome by confusion" (kebingungan) concerning ongoing events in Indonesia and the meaning of reformasi itself-"if you don't know, ask somebody who knows, what is reformasi." We are not told what is reformasi, but only advised that in such a time one had better be careful and not do anything reckless and try to avoid being possessed by an unspecified evil spirit; all these warnings express uncertainty and anxiety. Rather than a clearly defined political or social movement, for many people reformasi (and the "demontrasi here and there" that it involves) seem to evoke confusion and anxiety, and uncertainty ("this is the era of reformasi, they say"). In such conditions, all one can do is to be circumspect. The song ends with conventional advice to the "subjects," telling them to be calm, and with an appeal to God to bless Indonesia (the last part is reminiscent of the text of "Pamungkas," the composition-song often played at the end of a wayang performance).

117 Sujiwo Tejo's case is rather different from that of Manteb. While Manteb is originally and still very much primarily a dhalang and he lives in a village, Sujiwo Tejo, formerly a journalist, is a moderen artistintellectual living in Jakarta (even though he comes from a family of village dhalangs). 
164 Jan Mrázek

This is the era of reformasi, they say, there are demonstrations here and there, as if the earth was shaking. Oh mother! going north or south, one is overcome by confusion. It's like going to war, like on the battlefield, fighting to death, to prosper, to have cheap food and clothing.

This is the era of reformasi, don't do anything wrong, don't be ignorant, be careful, if you don't know, ask somebody who knows, what is reformasi. This is the era of restraint, everything has to be according to the rules, don't do anything reckless brother, don't become possessed by an evil spirit, you could then easily take the wrong road.

Always to live in harmony, so that the subjects are contented and quiet, may the Lord grant, Indonesia victorious forever. ${ }^{118}$

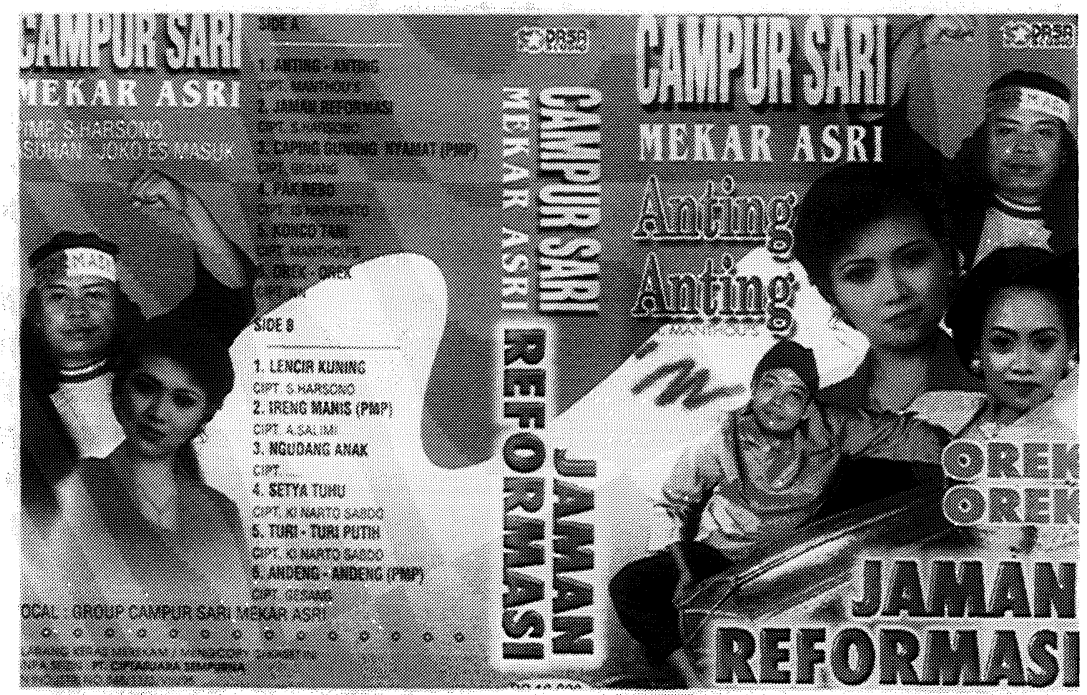

Figure 12. The Campursari cassette Jaman Reformasi ("The Reformasi Era").

Apart from his Campursari cassette bisnis, Crazy Djoko also plays kethoprak, a form of theater considered more popular or "lighter" than wayang (though this comparison does not hold if one considers actual wayang performances of popular dhalangs). Specifically, he and his new wife Nurhana have played in Ketoprak Reformasi, which was described as ketoprak mosaik, mixing various dramatic arts, old and new,

118 Jamane reformasi, khabare/kana-kene demontrasi/ bumine kaya digoncang, adhuh mak/ ngalor ngidul kebingungan. Bebasan maju perang, indhane/ matur kinten neng palagan/berjuang mati-matian/amrih makmur murah sandhang pangan. Jamane reformasi, aja salah aja lali, sing ati-ati/ yen kowe ora ngerti, takono karo sing ngerti, apa ta reformasi. Jamane perlu tahan, kabeh sarwa aturan, aja sembrana Mas/ Aja gampang kesusupan, karo pakartine setan, mengko mudah salah jalan. Sayuk rukun saumure, pamrihe/ ayem tentrem kawulane/ mugi Gusti amaringi/ Indonesia jaya salawase. Song by Harsono, on Campursari Mekar Asri, Jaman Reformasi, audio recording (Dasa Studio, n.d.). 
and it "tried to portray the era of reformasi though the lens of the art of ketoprak." Djoko has also composed parts of the dialogue. ${ }^{119}$

Djoko is not the only dhalang playing kethoprak. Let me focus on Manteb Soedarsono, and especially on his involvement in a new incarnation of kethoprak and a new television program, Ketoprak Humor. Ketoprak Humor is broadcast weekly on the RCTI television channel and has become extremely popular. Most of its members come from the Sri Mulat comedy, which I have discussed previously and which is also a popular weekly television show on the Indosiar channel. Many of the actors from Sri Mulat are famous and appear as stars in television commercials; they occasionally perform in large-scale wayang performances as guest stars, and one of them, Basuki, stars in a very popular television series. They make appearances in Ketoprak Humor as television celebrities, and they bring to kethoprak Sri Mulat's all-nonsense attitude, to what is considered traditional theater and to the Javanese history represented in the plays. Humor has been always important in kethoprak, in certain scenes and for certain kind of characters, but in Ketoprak Humor all the characters are comedians and the comedy is continuous. ${ }^{120}$ As in Sri Mulat, the story has the quality of stories in television sit-coms. A television program, Ketoprak Humor is and is called a "series" (serial). ${ }^{121}$

The simultaneous "humorization" and televisation (and Sri Mulat-ization) of the kethoprak theater is comparable to what has been happening to wayang as I have described it in this essay, but for us it is especially interesting because Manteb, the television dhalang celebrity par excellence, is also involved in Ketoprak Humor. For instance, he played the title role in the play "Dalang Soponyono" ("Puppeteer Whowouldexpectthat?"), which was broadcast in two parts to celebrate the Lebaran in January 1999. But he did not only play kethoprak; in the play Manteb/Puppeteer Whowouldexpectthat? also performed wayang kulit, and, as one could expect, Manteb/Puppeteer Whowouldexpectthat? performed a fight scene in which he displayed his dexterity in manipulating puppets, showing off the trik-trik akrobatik for which he is famous. In the story, Puppeteer Whowouldexpectthat? was invited to perform wayang at a wedding of a prince. In the middle of the performance, the electric lamp (blencong) illuminating the screen (and apparently all electricity in the ahistorical palace) went out, and when after a moment of total darkness light was restored, it was discovered that the Puppeteer Whowouldexpectthat? had eloped with the royal bride.

What is interesting in the context of this essay is wayang's and the top dhalang's presence in kethoprak on television. ${ }^{122}$ How does his presence as a dhalang in Ketoprak Humor compare to his presence as a dhalang in the weekly Indosiar wayang broadcasts, and more generally, how does it relate to his position as a dhalangcelebrity? What I find significant here is how closely his role in Ketoprak Humor

119 "Djoko 'Edan' Main Ketoprak," Suara Merdeka, July 31, 1998.

120 Apart from Sri Mulat, kethoprak plesetan, which emphasizes comedy, is an obvious predecessor of Ketoprak Humor.

121 “Ki Manteb Main Ketoprak Humor," Kedaulatan Rakyat, January 12, 1999.

122 As I have mentioned, Manteb played kethoprak before, though he never focused on it and his involvement in it has not been so conspicuous (e.g., discussed in the media) as recently. 
resembles his "role" on television, for which he is famous, and more generally, how those reflect the image of Manteb as a dhalang-celebrity. In Ketoprak Humor, Manteb is not just another kethoprak actor simply representing a character, but in many ways he performs himself. In a way this is comparable to Marilyn Monroe acting in a film-we don't see simply a character represented by an actor, but we see also the famous Marilyn Monroe, and people may watch the film because they want to see Marilyn Monroe (rather than a masterful representation of a character). But in the case of Manteb, his role as a dhalang in the play emphasizes his celebrity status as a famous dhalang, and the presence of the dhalang Manteb in or behind the character Soponyono is also highlighted by humorous allusions in the dialogues. This in turn tells us something about Manteb's presence when he performs wayang on television: in that case, too, he is representing himself, playing a role. We all do this, of course, but Manteb, when he acts as dhalang on television, plays specifically the role of a television celebrity. The distance between performing wayang on Indosiar as a dhalangcelebrity-in a sense, acting the role of dhalang on television-and his acting in Ketoprak Humor as a dhalang, is not very great. When he plays Ketoprak Humor, he is both Manteb and Soponyono-not simply Manteb-actor and Soponyono-character, but the dhalang-celebrity Manteb who often acts as dhalang on television, and Soponyono, a character created to accommodate the Manteb-celebrity and resembling Manteb. Manteb, when he appears on television, is involved in a complex play of various kinds of representation and televisual simulation of reality. Part of the joke intended when he represents dhalang Soponyono may be that not only the character of Soponyono, but also the identity of Manteb, are both products of a complex play of representations and simulated presences created by television, Manteb's role-playing in real life being part of that play. Wayang itself is of course involved in this play, and the question "what is wayang" is no less simple to answer than "who is Manteb." "What is wayang" is inseparable from the presence of wayang on television, whether it is in the weekly broadcast, in Ketoprak Humor, or in commercials.

In this essay I have discussed the very popular commercial involving Manteb performing wayang. His presence in that commercial is perhaps the clearest example of the way Manteb both is Manteb and acts Manteb on television in a typically televisual manner. A number of other commercials involving wayang have appeared more recently (1998-99). One of the most popular features Basuki, the comedian from Sri Mulat who now stars in Ketoprak Humor, in the soap opera Si Doel Anak Sekolahan (Basuki, a Javanese, acts a Javanese among the Betawi people on the outskirts of Jakarta), and in many television commercials. In the wayang commercial, Basuki acts as a dhalang. Here "to be a dhalang" becomes a role for an actor-comedian. This is a small step from those situations when a dhalang acts in the role of a dhalang on television.

This discussion of the dhalang's changing identity on television should be related to what I have said about the changing role of the dhalang in performances, and about older dhalangs' perceptions of younger, successful dhalangs as not being real dhalangs, as performers who are merely pretending to be dhalangs, but who are merely "TV-likeimages" of dhalangs. As I noted above, "The dhalang is more like an actor acting the part of a dhalang; the work itself is more acted, less performed, than in the past, and the real work, the making of the performance, is hidden." 
Indeed, it is interesting to see the continuity between the presence of wayang in Ketoprak Humor and the trends I pointed out several years ago. I discussed how in some cases wayang-the puppets, the puppeteer-becomes a "guest star" at a larger show. Essentially the same thing happens in Ketoprak Humor, where wayang becomes a part of another television program. I said that in large-scale performances the guest stars-comedians from wayang orang, kethoprak, Sri Mulat-become more central to wayang and the dhalang becomes only one among the actors from other genres. And essentially the same thing happens in Ketoprak Humor, where we see a dhalang, still acting as a dhalang and performing wayang, being just another actor, just another comedian. In the process I have discussed, the dhalang loses his traditional authority as the single most important performer. In 1999, speaking about his involvement in Ketoprak Humor, Manteb said "laughing loudly": "If usually I am the director [sutradara], now I will be directed [disutradarai]."123 If I have emphasized the way wayang mixes with and borrows from other media and genres, the appearance of wayang in Ketoprak Humor can be seen as another case of wayang interacting with other media, especially kethoprak, Sri Mulat, and television.

In this light, wayang in Ketoprak Humor suggests that many of the trends current before reformasi and krismon continue today, even as Manteb's involvement in Ketoprak Humor, like Crazy Djoko's involvement in the cassette industry, is also seen as a consequence of the economic situation. Certainly the presence of wayang in Ketoprak Humor, interesting as it may be, is not typical of wayang. But that wayang appears more and more often in atypical and diverse manners may itself be a typifying characteristic of wayang today-the strange and the new are especially marketable today.

In the same month that wayang appeared in Ketoprak Humor on the RCTI channel, wayang made another atypical appearance of this type on the Indosiar channel, at the time of the weekly "normal" wayang broadcasts. Presented to celebrate the fourth anniversary of Indosiar, the program was called Paket Wayang Spesial ("Special Wayang Packet"). ${ }^{124}$ What was spesial about the program was that it basically took wayang even further in the direction it has been moving. I have shown how the clown scenes are increasingly central to the wayang performance and how the whole performance is becoming more like the clown scenes. In Paket Wayang Spesial, the entire performance was made up of nothing but clown scenes; the whole first installment consisted of the Limbukan scene only, which is usually the first clown-scene in a wayang performance, and the second part, broadcast one week later, was the garagara, the second clown scene. Old dhalangs have for some years complained that the story does not receive enough attention in wayang performances nowadays. In Paket Wayang Spesial, there was no story. We have noted that guest stars, including guest stars and entertainments from "other regions," have played an important role in contemporary wayang. In Paket Wayang Spesial, the whole performance consisted of a presentation of various guest stars, including some of the most famous comedians,

123 “Ki Manteb ganti disutradari [sic]," Solo Pos, January 8, 1999.

124 For reports on this events, see "Indosiar Berulang Tahun Sederhana tapi Semarak," Suara Merdeka, January 11, 1999; "'Semarak' untuk HUT Indosiar," Kompas, January 11, 1999; "Lawak, Tari, dan Quasidah yang Segar," Kompas, January 16, 1999; "Malam Nanti, Semarak Empat Tahun Indosiar," Jawa Pos, January 11, 1999. 
168 Jan Mrázek

"regional songs" (lagu daerah), and "dances from the twenty-seven provinces." I have suggested that in recent performances the dhalang functions on occasion somewhat like a disc-jockey or master of ceremonies. In Paket Wayang Spesial, according to the Indosiar producer Didik Yulianto (whom I interviewed in February 1999), "the dhalang functioned as the MC." And I have emphasized the importance of wayang's interaction with television. Paket Wayang Spesial, for which the idea came from the Indosiar producer Didik, ${ }^{125}$ was a televisual event par excellence. "Modern technology forces traditional art to find a new format," writes one newspaper. ${ }^{126}$ Moreover, "next to the wayang kulit screen of the dhalang, Enthus Susmono, there was a giant monitor screen which showed various parts of the performance arena [arena]."127 I have suggested that at times it is not clear whether a large-scale wayang performance is still wayang, and that wayang now often becomes only one attraction in a show. This newspaper report examines what it calls "'deconstructed' wayang" [wayang yang telah 'didekonstruksi'] and observes that "the focus of the show is not only on the wayang screen and its accessories, such as the banana trunk where the puppets are placed, but rather also on various other aspects of the performance." The writer suggests that such a wayang performance is best described as a "'multimedia' show" (pertunjukan 'multimedia'), indicating that wayang has become one among a number of other media. And the writer wonders:

I don't know what the wayangan of dhalang Enthus Susmono should be called [entah harus disebut apa], when there is no story, there appear no good or bad characters, what there is are only funny characters. What's clear, here we see wayang, comedy, dance, and quasidah [Islamic singing], all pop and fresh [serba pop dan segar]. ${ }^{128}$

Another recent product of wayang's encounter with television, and another typically atypical incarnation of wayang, is what is in fact called telewayang. It was a serial intended mainly for children, 129 consisting of thirty-minute segments shown weekly on Saturday afternoons, beginning in January 1999. It was in fact created several years earlier, but in part for commercial and in part for political reasons, it was not shown on television until after the fall of Soeharto (though intended for children, it contains some quite obvious allusions to and parodies of the New Order government). Telewayang is quite unique because it uses newly created puppets and characters, and in many ways it differs from wayang: there are many puppet-manipulators, rather than a single dhalang, there is painted scenery, etc. Though apparently the series has not become very popular-probably because it is too different from what people think of as wayang-its appearance in the world of wayang today is quite fascinating. Here I mention it primarily as another example of the continuing interaction of wayang and other media.

The above examples show a continuity with the past in the sense that in them we can discern many of the trends that characterized wayang before the era of reformasi.

\footnotetext{
125 According to the puppeteer, Enthus Susmono, quoted in "Lawak, Tari, dan Quasidah yang Segar."

126 "Lawak, Tari, dan Quasidah yang Segar."

127 Ibid.

128 Ibid.

129 Arswendo Atmowiloto, personal communication, February 1999.
} 
The examples described above represent some of the most dramatic innovations or experiments, and in themselves are rather exceptional cases. If we look at performances that would still be considered new and more or less crazy by most people, but which are quite common or mainstream and very popular, the continuity with the past is even more evident. A performance by Crazy Djoko in May 1999 described in a newspaper article entitled "Ki Djoko 'Goes Crazy' in TMII," manifests no dramatic change of direction in its innovations, and in character it appears no different from Djoko's performance during the late New Order. "A majority of the spectators joined in 'going crazy' [ngedan] and screamed hysterically and danced when the performance arrived at the Limbukan and Goro-Goro segments [the clown scenes] that showed off Bagyo "Gareng" [the wayang orang comedian who had been very popular in Golkar's large-scale performances before reformasi] and female singers who could sing dangdut and [Sundanese] jaipong songs." 130 The female singers and the comedian stood up and danced on the stage, and Campursari songs were also featured. One of the functionaries present at the performance commented: "We are satisfied because the spectators were enthusiastic. As entertainment, this kind of show appears to be appropriate for people, and it was not politically tendentious. This can help against stress. What is important is to enjoy oneself, because wayang is indeed for the sake of entertaining people." 131

When we look at performances more generally, there is similar continuity in their character. There are fewer large-scale performances sponsored by the government (such as the two-screen performances), but medium- to small-size wayang performances continue to be frequent and popular, and in character they manifest the same trends as in the late New Order. Suratno wrote me in December 1999:

Emphasis is on songs in the clown scenes, including campursari pop songs, with the singers standing and dancing with the spectators. People do not pay attention to the story/play any more, and the sponsors ask that the clown scenes are longer and merrier, and if the story of the play is not finished [because so much time is taken up by the clown scenes], it is no problem. ${ }^{132}$

Suratno also mentioned that flash-back is increasingly popular-another symptom of wayang's interaction with film and television. I saw a number of performances when I was in Indonesia in January and February 1999. Sutomo Tomopandhoyo, for instance, a village dhalang popular in his limited area, still used disco lights, electric guitars, keyboard, and drum set, and his performances featured a comedian and two popmusic singers, next to the gamelan-music singers. Campursari, dangdut, pop Indonesia, and rock songs are played. Thus, there has been little change in these village performances in the last two years. This is not to say that there have been no changes in wayang performances or in the way it is in the world, but these changes seem no more dramatic than the changes in the late New Order period described in the body of this essay.

How should one explain the continuity in the character of wayang performances in a period when everybody is talking about dramatic change? If it is true that wayang

130 “Ki Djoko 'Ngedan' di TMII," Suara Merdeka, May 3, 1999.

131 Ibid.

132 Suratno, personal solonet correspondence from Solo, December 1999. 
170 Jan Mrázek

reflects the world, as Javanese people say, the continuity in wayang performances would suggest that there is a strong continuity in the way that most people live their lives, a continuity which may be overshadowed by a journalistic focus on change (the new sells well, as we know from young dhalangs). Things are more expensive and people have less money, which affects many people severely, but other people less so. But Warung Mbak Sri continues to make excellent gado-gado, the woman at that other place is still mean and mixes coal and burned corn into coffee as she did before (though she may be even meaner and use even less coffee beans than before), people still show off their refrigerators, motorbikes, and television sets, and also (this is new) VCD players to impress their neighbors and guests, if they can afford it, or if they cannot they wish they could, and perhaps even dream of having a " $\mathrm{HP}^{\prime}$ (hand phone), and I hear that the students at the prestigious Tri Sakti University in Jakarta continue to buy the latest models of HPs. Not that nothing would change. I began this postscript by writing about contingency and uncertainty about the future, and when I was in Indonesia in 1999, uncertainty and anxiety were in the atmosphere. It was not like what I expected from reading the reports in newspapers and watching television, which always focus only on the most dramatic moments and places and ignore the way that everyday life goes on, but streets were somewhat quieter than usual, as some people felt uneasy about going out at night (e.g., to a wayang performance) and the economic crisis also made more people stay at home. But people's obsessions, tastes, habits, views, and ways of living have a great inertia.

Secondly, what is at stake are not simply people's lives, but wayang as a medium or a form of theater or entertainment. While in one perspective wayang can be seen as an expression of who people are, from another perspective, which is no less true, people's lives can be seen to move around wayang. They struggle about the form it should take, or, perhaps more often, they continue to enjoy it, continue to live with it, and performers continue to "work" it as people work their fields, and try to serve the fields, try to understand what the fields require from them and try to give it to themin order that the fields may serve people. Or possibly they act as shopkeepers who sell what people ask for and what they need in their everyday life. The change of government does not necessarily effect what I like to eat or drink, though an economic crisis may affect what I can get.

I have discussed previously the similarities between PKI wayang performances in the mid-sixties and later Golkar or New Order performances, and I have quoted Ruth $\mathrm{McVey}$, who sees these similarities in the context of "a shared participation in the moderen culture." The continuity in wayang performances in recent years, despite the political changes, can also be understood in the context of a continuity of "moderen culture," or a moderen world-something more than politics, but something of which politics is a part, and something that forms the horizon against which people create and make sense of politics, if they are involved in them. This "something larger" is ever changing, but if we look at this heterogeneous whole, we can see more clearly a continuity in the world than if we look at politics alone, and trying to see this larger picture, a picture that includes those not in power and those not involved in politics, that includes people's everyday worries and obsessions as well as the routine of life and the way people try to break that routine by going to a dangdut concert or a wayang performance, helps us to get a truer picture of what is happening. 
Specifically in the case of wayang, we need to get a feeling for the coexistence of the very innovative and the more or less old-fashioned; of puppeteers who are closely associated with a political party and those who are ostensibly neutral, as well as those who get involved in party politics and even thinking about politics as little as possible; of the rare political-rally-like wayangs and the more common performances in which politics are not central; of the way that even apparently very politicized wayang performances are for many people primarily entertainment; of the fact that for dhalangs political parties are often simply paying sponsors; of the way that the talk of reformasi occurs as a part of entertainment between or in pop songs and jokes, and many performers and performances are not primarily concerned with national politics; of people's uncertainty, confusion, and anxiety, new and old, and their ability to relax and enjoy themselves, if at all possible.

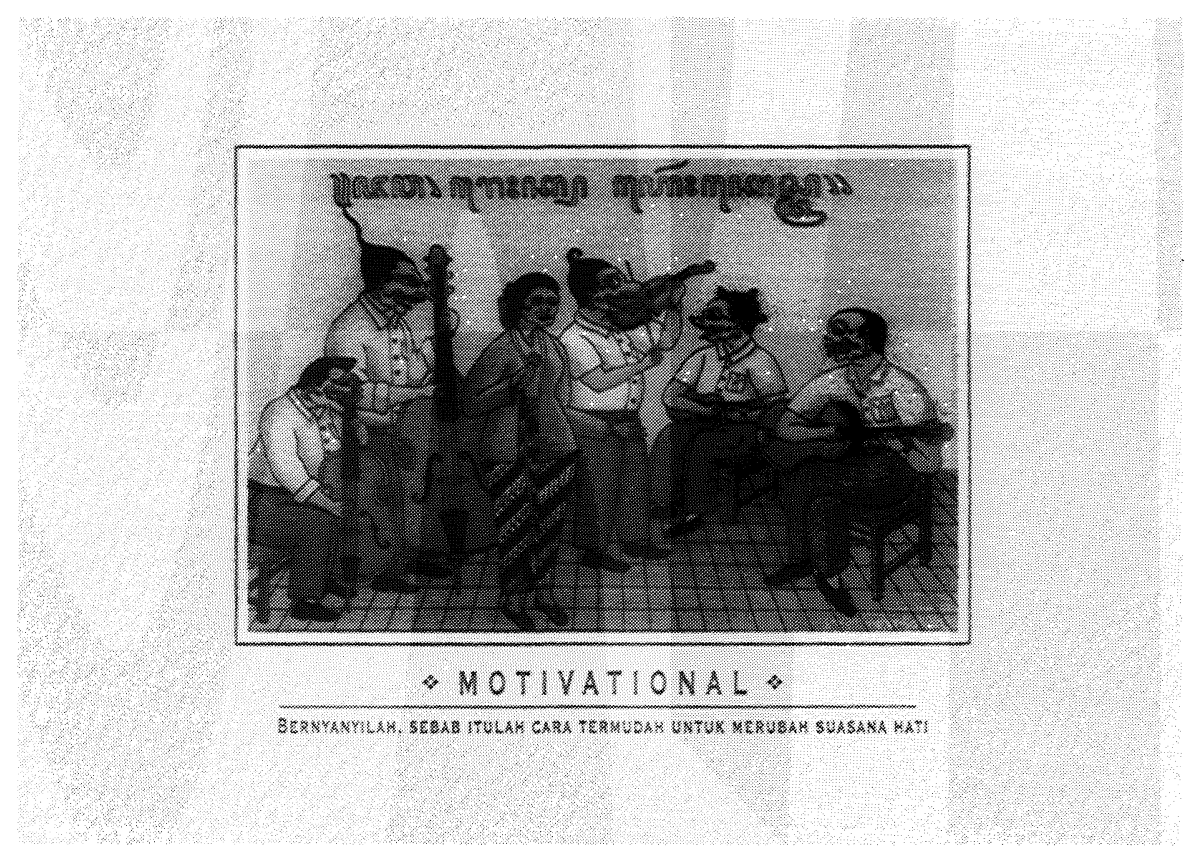

Figure 13. I received this motivational postcard from a friend after I had finished writing the postscript. In the picture, there are the clown-servants from wayang, wearing pants and shirts and playing Western music instruments, and a female singer holding a microphone. The Javanese text in the picture is Jawa Rok Orkes ("Javanese Rock Orchestra"), and the Indonesian text below the word "MOTIVATIONAL" translates: "Sing, for that is the easiest way to change the mood of the heart." (For this postcard I thank the HJL and VA A AVMI bands.)

In conclusion, we can say that, as it was before the era of reformasi, being in the world-for wayang and its performers-continues to be no simple matter, and thatperhaps in part because it lets itself be affected by various forces, often conflicting forces-wayang continues to appeal to audiences. Wayang continues to be open to the present and continues to develop and change, continues to maneuver among the various forces in the present world, but the way it is open to the world and the directions in which this opening has developed, the directions of the innovations, these 
172 Jan Mrázek

have not dramatically changed in the last two years, or at least they haven't changed any more dramatically than in the two years before. People are still fascinated by the foreign, the internasional, the moderen, they play rock songs on gamelan and make wayang-puppets of television celebrities, at the same time that they continue to enjoy some older gamelan pieces and much else in wayang. They still like or need to have fun, to listen to music and watch the pretty female singers, to laugh at the familiar and at the strange, at themselves and the foreign, at what they like and dislike, at jokes new and old. Puppeteers have not run out of stories, Semar farts more persistently and uncontrollably than ever ("in new contexts and with new significances," the scholar in me says), Gareng continues to make obscene (some say silly) jokes, and the times of comedy are not quite over yet. 